Florida International University FIU Digital Commons

FIU Electronic Theses and Dissertations

University Graduate School

6-19-2017

\title{
The Impact of Transitional Justice on the Development of the Rule of Law
}

Craig Lang

Franklin and Marshall College, clang023@fiu.edu

DOI: $10.25148 /$ etd.FIDC001931

Follow this and additional works at: https:// digitalcommons.fiu.edu/etd

Part of the Comparative Politics Commons, and the International Relations Commons

\section{Recommended Citation}

Lang, Craig, "The Impact of Transitional Justice on the Development of the Rule of Law" (2017). FIU Electronic Theses and Dissertations. 3465.

https://digitalcommons.fiu.edu/etd/3465

This work is brought to you for free and open access by the University Graduate School at FIU Digital Commons. It has been accepted for inclusion in FIU Electronic Theses and Dissertations by an authorized administrator of FIU Digital Commons. For more information, please contact dcc@fiu.edu. 


\section{FLORIDA INTERNATIONAL UNIVERSITY}

Miami, Florida

THE IMPACT OF TRANSITIONAL JUSTICE ON THE DEVELOPMENT OF THE

RULE OF LAW

A dissertation submitted in partial fulfillment of the

requirements for the degree of

DOCTOR OF PHILOSOPHY

in

POLITICAL SCIENCE

by

Craig Lang

2017 
To: Dean John F. Stack, Jr.

Steven J. Green School of International and Public Affairs

This dissertation, written by Craig Lang, and entitled The Impact of Transitional Justice on the Development of the Rule of Law, having been approved in respect to style and intellectual content, is referred to you for judgment.

We have read this dissertation and recommend that it be approved.

Barry Levitt

Markus Thiel

Harry Rhea

Elvira Maria Restrepo

Tatiana Kostadinova, Major Professor

Date of Defense: June 19, 2017

The dissertation of Craig Lang is approved.

Dean John F. Stack, Jr. Steven J. Green School of International and Public Affairs

Andres G. Gil

Vice President for Research and Economic Development and Dean of the University Graduate School

Florida International University, 2017 


\section{DEDICATION}

I dedicate this dissertation to my parents and my wife. My parents were the first to introduce to me the importance of an education, and without the support of my wife and family, I never would have been able to undertake this project. 


\section{ACKNOWLEDGMENTS}

I would like to thank the members of my committee for their encouragement and intellectual support throughout this challenging process. Thank you for divesting so much of your time and energies; your keen insights, recommendations and expertise have been invaluable. In particular, I wish to thank my major professor, Dr. Tatiana Kostadinova, for her unwavering personal and academic support. You have been my mentor and champion since my first semester at Florida International University. I am indebted to you for your help in shaping me as a scholar and teacher. I also wish to recognize the late Dr. Rebecca Salokar, who also served on my committee. She too helped develop my skills in the classroom, and she never stopped encouraging me to "just get it done!"

I would also like to thank Dr. John F. Stack and the Steven J. Green School of International and Public Affairs. The financial support received through a Broad Research Fellowship, as well as funding through the Miami-Florida Jean Monnet European Centre of Excellence, funded the fieldwork for this project. 


\title{
ABSTRACT OF THE DISSERTATION \\ THE IMPACT OF TRANSITIONAL JUSTICE ON THE \\ DEVELOPMENT OF THE RULE OF LAW
}

\author{
by \\ Craig Lang \\ Florida International University, 2017 \\ Miami, Florida \\ Professor Tatiana Kostadinova, Major Professor
}

Little is known about the effects of transitional justice on the development of the rule of law in post-conflict states. There are assumptions in the literature that the prosecution of those responsible for human rights violations or convening a truth commission will help improve the rule of law. Using a mixed-method approach, which combined statistical analysis with in-country fieldwork, this investigation found that the impact of transitional justice, particularly trials, on the development of the rule of law is minimal and not automatic. In each of the four states examined, Colombia, Peru, Bosnia and Herzegovina and Kosovo, meaningful effects from transitional justice were blocked by powerful postconflict inhibiters, including a lack of state capacity, ethnicity and corruption. These findings indicate that prior assumptions about the relationship between transitional justice and the rule of law are overstated, and they point to the need for policymakers to simultaneously address these and other inhibiters while implementing transitional mechanisms. 


\section{TABLE OF CONTENTS}

CHAPTER

PAGE

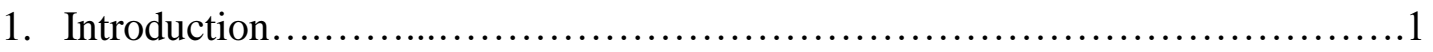

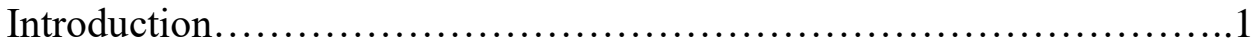

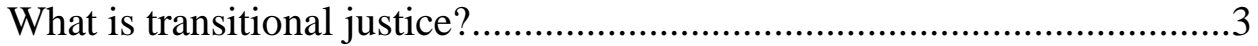

Assessing What We Know...........................................

Mechanism Selection and Implementation............................12

The Theoretical Boundaries of This Analysis.............................14

Research Design............................................... 18

1. Cases.................................................

2. Methodology ........................................... 20

Structure of the Dissertation........................................22

2. Toward a Deeper Understanding of the Relationship Between Transitional Justice

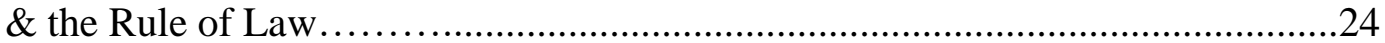

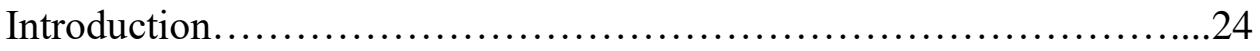

Measuring the Rule of Law.........................................25

Measuring Transitional Justice......................................27

Changes in the Rule of Law: Descriptive Analysis........................30

Rule of Law Levels..........................................30

Comparing \& Contrasting.......................................33

The Rule of Law \& Transitional Justice.........................35

Test of Correlation................................................. 41

Control Variables............................................41

Regression Analysis.......................................42

Conclusion...................................................... 45

3. Colombia: The Introduction of Truth, Justice and Reparations....................48

Introduction...................................................... 48

The Introduction of Truth, Justice \& Reparations.......................54

The Design of Truth, Justice \& Reparations..............................66

Implementation of Law 975 \& Its Effects..............................73

Government Subordinate to the Law \& Equality of All Before the

Law.........................................................73

Law \& Order............................................ 78

Predictable \& Efficient Justice.................................88

Upholding Human Rights.................................. 94

Concluding Thoughts \& Recommendations...........................98

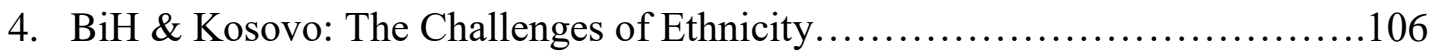

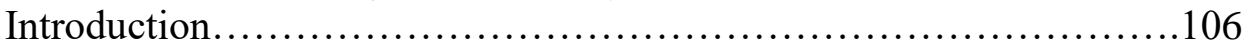

The Transitional Justice Framework...................................108

Model Design: International Imposition to a Balanced Approach.......118 
Transitional Justice \& Its Effects.....................................128 Government Subordinate to the Law \& Equality of All Before the Law 129

Law \& Order............................................141

Predictable \& Efficient Justice...................................146

Upholding Human Rights..................................154

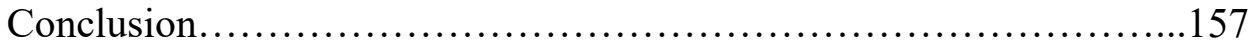

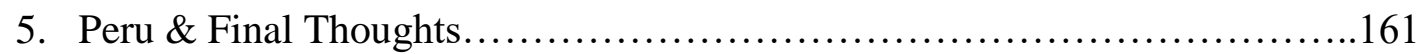

Introduction..........................................................

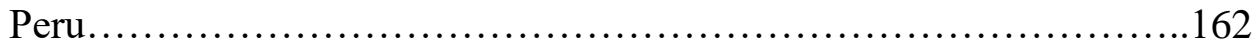

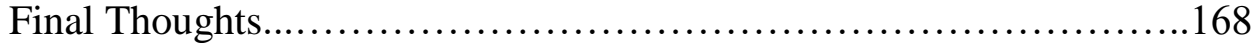

Way Ahead............................................................

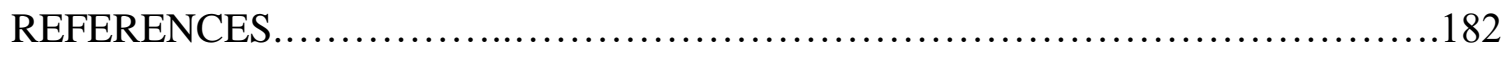

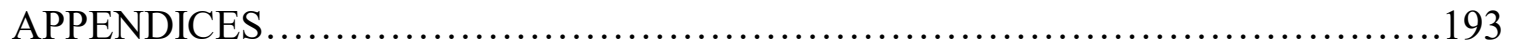

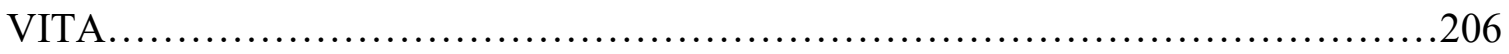




\section{LIST OF TABLES}

TABLE

PAGE

2.1 Transitional Justice Mechanisms Used or In Use............................. 30

2.2 Latin American Rule of Law Comparisons..................................34

2.3 Southeastern Europe Rule of Law Comparisons...............................34

2.4 Rule of Law Before \& After Initiating Transitional Justice (comparing means).....35

2.5 Changes in Procedural and Substantive Areas of the Rule of Law...................37

2.6 Mixed-Effects Regression Results........................................45

3.1 Colombians' Trust in the Judiciary and Police..................................84

4.1 Murder Rates in $\mathrm{BiH}$ and Kosovo (per 100,000 people) $\ldots \ldots \ldots \ldots \ldots \ldots \ldots \ldots \ldots \ldots$

4.2 Protection of Civil Liberties in $\mathrm{BiH}$ and Kosovo (1996-2015)..................155

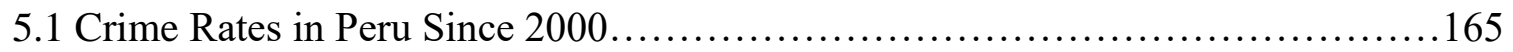




\section{LIST OF FIGURES}

FIGURE

PAGE

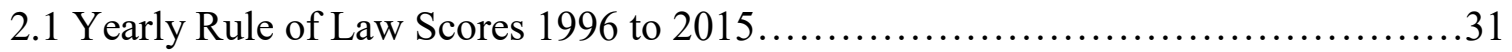

2.2 The Rule of Law with International and Mixed Models of Transitional Justice.......36

2.3 Rule of Law Scores \& Models of Transitional Justice............................46

3.1 Colombia's Yearly Level of the Rule of Law.................................50

3.2 Number of Yearly Kidnappings and Civilian Conflict Deaths....................80

3.3 Perceived Level of Corruption in Colombia: 1996-2015 ......................102

4.1 The Rule of Law in Bosnia \& Herzegovina................................... 106

4.2 The Rule of Law in Kosovo............................................ 107

5.1 Models of Transitional Justice and Rule of Law Scores..........................171 


\section{ABBREVIATIONS AND ACRONYMS}

\begin{tabular}{|c|c|}
\hline AUC & United Self-Defense Forces of Colombia \\
\hline BACRIM & Bandas Criminales (Criminal Bands) \\
\hline $\mathrm{BiH}$ & Bosnia and Herzegovina \\
\hline BTI & Bertelsmann Transformation Index \\
\hline CVR & Truth and Reconciliation Commission \\
\hline DDR & Disarmament, Demobilization and Reintegration \\
\hline $\mathrm{EC}$ & European Commission \\
\hline ELN & National Liberation Army \\
\hline EULEX & European Union Rule of Law Mission in Kosovo \\
\hline FARC & Revolutionary Armed Forces of Colombia \\
\hline FRY & Federal Republic of Yugoslavia \\
\hline ICJ & International Court of Justice \\
\hline ICTY & International Criminal Tribunal for the Former Yugoslavia \\
\hline KLA & Kosovo Liberation Army \\
\hline LAPOP & Latin American Public Opinion Project \\
\hline LFP & Legal Framework for Peace \\
\hline MAPP/OEA & $\begin{array}{l}\text { Organization of American States Mission to Support the Peace } \\
\text { Process in Colombia }\end{array}$ \\
\hline NCRR & National Commission for Reparation and Reconciliation \\
\hline OAS & Organization of American States \\
\hline OSCE & Organization for Security and Cooperation in Europe \\
\hline OHR & Office of the High Representative \\
\hline
\end{tabular}




$\begin{array}{ll}\text { PIC } & \text { Peace Implementation Council } \\ \text { PTS } & \text { Political Terror Scale } \\ \text { RS } & \text { Republika Srpska } \\ \text { SFRY } & \text { Socialist Federal Republic of Yugoslavia } \\ \text { UNDP } & \text { United Nations Development Program } \\ \text { UNMIK } & \text { United Nations Mission in Kosovo } \\ \text { UNODC } & \text { United Nations Office on Drugs and Crime } \\ \text { UNSYG } & \text { United Nations Secretary General } \\ \text { WCC } & \text { War Crimes Chamber } \\ \text { WGI } & \text { Worldwide Governance Indicators }\end{array}$




\section{Chapter 1 \\ Introduction}

\section{Introduction}

If one were to analyze together Colombia, Peru, Bosnia and Herzegovina (BiH) and Kosovo, it is unlikely that this group would be put forward as a model for the rule of law. Colombia has wrestled with guerilla insurgencies, right-wing paramilitaries and criminal organizations for 53 years, Peru is one of the leading producers of cocaine and both $\mathrm{BiH}$ and Kosovo are two of the more corrupt countries in Europe. ${ }^{1}$ Yet combined, these four countries possess more than 60 years of experience with varying mechanisms of transitional justice, which is generally understood as an array of processes, both judicial and non-judicial, used by governments to address previous human rights abuses and political violence. Moreover, the transitional justice literature is replete with testaments by scholars and practitioners that transitional justice, particularly trials, aids in the development of the rule of law. (Sikkink 2011, 155, Weiffen 2012, 10 and Stromseth 2006, 254)

Although some of the processes are still ongoing in the aforementioned states, it has been anywhere from 11 to 23 years since transitional justice began in these countries. Consequently, it is fair to ask after so much time, effort and money, did transitional justice make a difference, namely did the use of transitional justice in these four postconflict states help or deter in the development of the rule of law? That is the central question of this study, and a very important one considering that Colombia is beginning

\footnotetext{
${ }^{1}$ Transparency International ranks BiH 38 and Kosovo 33 out of 100 (very clean) on their 2015 Corruption Perceptions Index, which can be found at https://www.transparency.org/country/.
} 
another wave of transitional justice as part of the 2016 peace accord between the Revolutionary Armed Forces of Colombia (FARC) and the Colombian government. Furthermore, the government of Kosovo agreed in 2015 with the international community to establish the Specialist Chambers, which is a Kosovo-only international war crimes tribunal in The Hague, Netherlands, and the International Criminal Tribunal for the Former Yugoslavia (ICTY), which adjudicated cases from both BiH and Kosovo, is nearing its 25-year anniversary in 2018.

In light of these ongoing transitional justice processes, the plans to introduce new mechanisms, and the widespread use of this type of justice globally, answers are urgently needed about the effects of such things as trials and truth commissions in post-conflict states. Scholars have recently begun the arduous task of examining several important questions related to the implementation and effects of transitional justice, but gaps remain, particularly when it comes to understanding the relationship between transitional justice and the rule of law. Based upon a mix of qualitative and quantitative research, this study finds that the ability of transitional justice to deliver improvements in the rule of law is not automatic. Although there were some minor improvements to the rule of law that can be traced back to transitional justice in three of these four states, more meaningful reform was blocked by powerful post-conflict inhibiters, such as a lack of state capacity, insufficient resources, ethnic polarization and endemic corruption. Yet, before digging into these and other findings, the rest of Chapter One is dedicated to situating this study within the literature, as well as outlining this study's research design. 


\section{What is transitional justice?}

Initially emerging as a distinct area of scholarship following the democratic transitions that were part of the Third Wave of Democracy, transitional justice during these early years consisted primarily of a new democratic government's attempt to address the human rights violations of the prior regime through trials, truth-telling, reparations and government purges. ${ }^{2}$ (Arthur 2009, 326, 329) Although initially part of democratic transitology, the boundaries of transitional justice are expanding, and its mechanisms are now being increasingly utilized in post-conflict environments, which do not necessarily involve changes in the type of government. For example, between 1970 to 2005, transitional justice, aka, post-conflict justice, was used in 94 cases of civil war. ${ }^{3}$ (Reiter, Olsen and Payne 2013, 158) Moreover, a review of the work of the International Center for Transitional Justice shows this non-governmental organization currently active in 32 countries across five continents, many of which involve transitions from war to peace. ${ }^{4}$ Consequently, transitional justice has reached a routine, steady state, and it has now become "obligatory" in many transitional contexts. (Teitel 2003, 89 and Subotic 2009, 5, 22)

Yet, despite its expanded application, the central mechanisms remain largely the same. Binningsbo, et al., catalog trials, truth commissions, reparations, amnesties, government purges (lustration) and exiles as the go-to tools in the post-conflict toolkit.

\footnotetext{
${ }^{2}$ The Third Wave of Democracy is the period during the 1970s-early1990s where democratic transitions occurred worldwide. This period is best explained in Samuel Huntington's 1991 book, The Third Wave: Democratization in the Late Twentieth Century.

${ }^{3}$ Scholars, such as Binningsbo, et al., use the term "post-conflict justice" to refer to transitional justice used in post-conflict states. For this study, both terms will be used interchangeably.

${ }^{4}$ https://www.ictj.org/our-work (Accessed August 26, 2016)
} 
$(2012,733)$ Capturing the ability of transitional justice to serve both transitions to democracy and peace, Olsen, Payne and Reiter (2010) define transitional justice as, “...the array of processes designed to address past human rights violations following periods of political turmoil, state repression, or armed conflict." (11) Offering a slightly different take, Serrano explains transitional justice as, “...the activation of complementary judicial, quasi-judicial and non-judicial mechanisms aimed at addressing past human rights violations while embarking on a major political transformation." (Serrano in Popovski \& Serrano 2012,467) Regardless of which definition one chooses, it is clear that transitional justice, whether as part of a democratic transition or peacebuilding program, has been recognized as a policy that entails a set of shared mechanisms and purposes, namely to facilitate a political change and address political violence. (Arthur 2009, 355 and Leebaw 2008, 106)

Yet, while there is clarity about what is transitional justice, the field is only beginning to understand its effects. As structured, transitional justice has both short and long-term goals. In the short-term, utilizing truth commissions and other mechanisms should promote stability and peace; whereas in the long-term, scholars and practitioners express more aspirational goals, such as consolidating democracy and building the rule of law. (Leebaw 2008, 101) As outlined earlier, this study is primarily concerned with analyzing one anticipated long-term effect, transitional justice's ability to aid in the development of the rule of law.

\section{Assessing What We Know}

Following their comprehensive examination of the transitional justice literature, Thoms, Ron and Paris note, "Our principal finding is that reliable empirical knowledge 
on the state-level impacts of transitional justice is still limited." $(2010,331)$ They go on to explain that the lack of empirical research is due to the largely qualitative, single-case studies done by transitional scholars. Echoing this refrain, Olsen, Payne, and Reiter (2010, 134) add that many of the prior studies were not only single case studies, but they also only evaluated one mechanism. Explaining that both practitioners and policymakers have "overloaded expectations" of transitional justice, the aforementioned authors lament, "The proliferation of mechanisms and these divergent interpretations of their success notwithstanding, we know very little about whether transitional justice actually achieves the lofty goals it promises." (Ibid, 134) Subsequently, what became abundantly clear as the field developed was the need for a range of studies to test the causal claims previous scholars had outlined, as well as assess the effectiveness of the various tools of transitional justice. Fortunately, scholars like Olsen and others have recently begun to address this empirical shortfall. Consequently, the literature now embodies a more empirical flavor. A new generation of transitional justice scholars is claiming that the field, at least methodologically, has entered a new wave, one which seeks to more accurately measure the impact of transitional justice vis-à-vis its effects on concepts like human security, which includes the rule of law. (Balasco 2013, 205-08)

In light of its roots in democratic transitions and later peacebuilding, many of the earlier single case studies and more recent large- $\mathrm{N}$ projects examined the relationship between transitional justice and democracy or transitional justice and the promotion of peace. For example, although they only examined trials, truth commissions and amnesties, Olsen, Payne, and Reiter (2010) find that if transitional justice is to promote democracy and human rights, a holistic approach is required. Labeling this approach the 
"justice balance," the authors find that trials with amnesties or trials, truth commissions and amnesties work together to improve democracy and human rights. They argue that these blends of mechanisms are effective because they balance accountability with restorative elements.

Utilizing much of the quantitative data that led to their earlier findings, these same scholars, in a separate study, narrowed the range of cases to only those that experienced civil war or an internal conflict from 1970 to 2005. Based upon this range of cases, transitional justice is not a necessary condition for maintaining peace; peace was sustained in the majority of countries with or without the use of transitional justice. (Reiter, Olsen, and Payne 2013, 165) Looking specifically at Latin America, a 2015 study by Dancy and Wiebelhaus-Brahm identify trials, particularly if held within five years of the democratic transition, as the closest of all the mechanisms as being a necessary condition for democratic consolidation. Yet, this study also points out that any mechanism on its own is not sufficient for solidifying democracy; in line with Olsen, et al.'s argument for a justice balance, this study also supports pairing amnesties with trials in order to help with democratic consolidation. In addition to providing valuable insights into the link between transitional justice and democracy, this Latin American analysis also notes that the timing and sequencing of mechanisms are not important for ensuring an enduring democratic state. (336-340)

While rightly recognized as advancing the field of transitional justice, the aforementioned studies do not address the relationship between transitional justice and the rule of law. For example, while Reiter et al., found that transitional justice has no effect on sustaining peace, the question remains whether the use of transitional justice 
impacts other post-conflict goals, such as solidifying the rule of law. Olsen, Payne, and Reiter $(2010,161)$ acknowledge this shortcoming stating, "Perceptions of justice, fairness, or rule of law may provide a more valuable measure of success than improvements in democracy and human rights indicators..." While scholars have been slow to assess the relationship between the rule of law and transitional justice, policymakers and practitioners have been operating under the assumption of a positive relationship for quite some time.

In a 2004 report on transitional justice and the rule of law, former United Nations (UN) Secretary General Kofi Annan recognized this link, claiming that the two UN ad hoc tribunals created for Rwanda and the former Yugoslavia were established, in part, to re-establish the rule of law in these two regions. $(7,13)$ In fact, the International Criminal Tribunal for the Former Yugoslavia publicly claims that one of its achievements has been strengthening the rule of law in the countries of the former Yugoslavia. On its website, the ICTY contends, "The Tribunal works in partnership with domestic courts in the region - transferring its evidence, knowledge and jurisprudence - as part of its continuing efforts to strengthen the rule of law and to bring justice to victims in the former Yugoslavia." In other parts of the world, similar claims are made about other transitional mechanisms. For example, South Africa's Truth and Reconciliation Commission, along with the hybrid courts in Cambodia, both believed that their work strengthened the rule of law in their respective countries. (Gibson, Sonis and Hean 2010, 378-79)

\footnotetext{
${ }^{5}$ http://www.icty.org/en/about/tribunal/achievements (Accessed August 27, 2016)
} 
Helping build a theoretical framework for such a relationship, Stromseth, Wippman and Brooks (2006, chap. 7) foresee a connection between transitional justice and the rule of law when accountability proceedings, such as trials, have a sufficient demonstration effect and build local capacity. The demonstration effect is powerful because it signals to society that impunity will no longer be tolerated. Conversely, if trials are conducted in a manner that demonstrates bias or lack of transparency, transitional justice can have a negative effect. And, consistent with the aforementioned findings on the need for a justice balance, these authors echo their support of this idea by noting that trials may not be enough to promote the rule of law. A more holistic approach, such as that utilized in transitional justice proceedings in places like East Timor and Sierra Leone may be more successful. A more comprehensive use of mechanisms may be needed because these other programs, such as truths commissions and reparations, directly impact more people and build greater local support.

Building upon the theoretical framework erected by Stromseth, et al., a series of more recent empirical studies attempt to uncover if such a relationship exists between transitional justice and the rule of law. Based upon an examination of law and order scores, Sikkink $(2011,156)$ claims that the development of the rule of law in several Latin American states went hand-in-hand with the use of human rights trials. Of the 14 countries that used human rights trials in Latin America following their democratic transitions, Sikkink finds that 10 of them had improved law and order scores. To that end, she notes, "...human rights trials and the construction of the rule of law can be two simultaneous and mutually reinforcing processes." (Sikkink in Popovski \& Serrano 2012, 34) Yet, while Sikkink herself acknowledges the need for more rigorous empirical 
testing, she does not do so, citing the difficulty in defining and measuring the rule of law. (Sikkink 2011, 155-156) Consequently, due to the lack of more sophisticated statistical analysis, along with questions surrounding her sole use of the Law and Order index as a comprehensive measurement for the rule of law, Sikkink's analysis has limitations.

In another recent analysis, Weiffen (2012) discovers a high correlation between a government's use of reconciliation policies and higher rule of law scores. Additionally, Weiffen finds that in countries that used domestic human rights trials between 1979 and 2004, these countries' rule of law scores were higher than in states that did not hold trials. Unfortunately, here too, multivariate regression analysis was not utilized to isolate other factors, nor was an attempt made to identify the impact of distinct transitional justice mechanisms on the rule of law. Furthermore, Weiffen's findings regarding the use of domestic trials fail to say anything about countries that have been subject to international tribunals or hybrid courts.

Providing one of the strongest empirical examinations of the rule of law in a postconflict environment, Haggard and Tiede (2014) evaluate a country's level of the rule of law before, during and after an internal conflict. Utilizing descriptive and inferential statistics, these two find that the rule of law is largely path dependent, i.e., the rule of law does not generally change from pre-and post-conflict levels. According to their results, the only measurement of the rule of law that improves after a conflict is the level of executive constraints, which not surprisingly are enhanced following the cessation of violence. While providing an important contribution to rule of law studies, namely the importance of understanding path dependency, these authors did not control for a country's use of transitional justice. Interestingly, in my review of their structural break 
analysis, several countries that had strong or modest improvements in their rule of law scores were also countries that utilized transitional justice, namely Croatia, Peru, Argentina and Rwanda. And, while not discussing transitional justice directly, these scholars admit to limitations, primarily the inability to explain variations in rule of law levels. Subsequently, further research is needed employing a control for transitional justice to see if this may be one factor that can help explain variations in levels of the rule of law.

Another seminal work that encourages caution when claiming a link between transitional justice, primarily trials, and the rule of law is the 2003/2004 study by Snyder and Vinjamuri. Following their examination of 32 civil war cases, these authors argue that the legalist approach, i.e., accountability proceedings are the appropriate response to widespread human rights abuses in all transitional contexts, may be counter-productive to transitional justice's long-term goals. (14-15) Describing their findings, the two scholars argue, "When a country's political institutions are weak, when forces of reform there have not won a decisive victory, and when potential spoilers are strong, attempts to put perpetrators of atrocities on trial are likely to increase the risk of violent conflict and further abuses, and therefore hinder the institutionalization of the rule of law." (Ibid, 15)

In light of the varying methodologies and conflicting findings, it is apparent that several questions and gaps remain, which this research attempts to fill. Primarily, the failure of previous studies to control for other factors limits our ability to state with any degree of certainty that transitional justice was responsible, in whole or in part, for the increases in the rule of law identified by Sikkink and Weiffen. Secondly, this project aims to support in the development of a theory of change for transitional justice. After 
reviewing 273 articles, books and working papers on transitional justice, Macdonald laments, “...transitional justice policy lacks a clear 'theory of change,' that is, it has no clear understanding of how change works. Therefore, even if ends are identified, it is unclear how we get there." $(2015,115)$

Although several of the aforementioned works make claims of correlation or causation, the literature thus far has not identified how a mechanism affects the rule of law, i.e., it provides no theory of change. For instance, while Sikkink provides a compelling case that human rights trials helped improve law and order in 10 countries in Latin America, her study fails to explain concretely how. In several of these countries, such as Peru and Argentina, trials were utilized alongside other transitional justice mechanisms. While it is logical that trials greatly influence the rule of law, it is equally plausible that other transitional justice mechanisms also influence this phenomenon.

Moreover, based upon a review of the literature that discusses the why, how and when mechanisms of transitional justice are chosen and implemented, it is also conceivable that the manner of procedural selection and implementation impacts either positively or negatively the ability of transitional justice to help develop the rule of law. For instance, it is hypothesized as part of this analysis that when states participate in choosing and governing their own processes of transitional justice, the rule of law develops more rapidly than when transitional policies are imposed by the international community. The ability to design and implement these mechanisms is theoretically important to their long-term success because this involvement fosters a sense of local ownership and accountability. 


\section{Mechanism Selection and Implementation}

While much has been written about the political factors that impact decisions whether to use transitional justice, particularly the importance of the distribution of power between incoming and outgoing elites, this study is not concerned with the questions of if and why. ${ }^{6}$ Instead, what needs to be understood within this context, is the procedure by which mechanism decisions are made and implemented, namely is it domestically-generated and implemented or internationally-imposed and executed. Why is this important?

Fletcher, Weinstein and Rowen (2009) argue that the level of a country's autonomy from the international community, along with the legacy of colonialism and cultural traditions, determine which mechanisms are selected. Moreover, when the international community intervenes within a weak state, outside forces dictate the model of transitional justice used. (208) Concerned with international imposition as well, Turner (2008) contends that the international community imposes models of transitional justice and international law on states in the hopes of achieving stability and democracy. (128) Yet, according to Turner, imposition could actually have deleterious effects because, "By relying on a narrow and pre-defined course of action for peace-building, however, and by equating peace with a particular set of political norms and beliefs, the international

\footnotetext{
${ }^{6}$ For works that discuss elite competition, see Huntington, Samuel P. 1991. The Third Wave: Democratization in the Late Twentieth Century. (Norman, OK: University of Oklahoma) and O'Donnell, Guillermo and Philippe C. Schmitter. 1986. Transitions from Authoritarian Rule: Tentative Conclusions about Uncertain Democracies. (Baltimore: The Johns Hopkins University).
} 
community risks restricting the options open to countries in transition, and thus undermining their progress towards peace and stability." (133)

While not arguing that outsiders completely refrain from involvement in others' transitional justice processes, the international community should be facilitators and not the final arbiters. Only when laws are generated internally will they be perceived as legitimate. (Ibid, 138) In addition to the possibility that mechanisms externally imposed may have negative effects, transitional justice foisted upon a country may be used by domestic elites in ways the international community did not anticipate, and hence disrupt either the short or long-term goals. For example, in Southeastern Europe, Subotic argues that the ICTY was "hijacked" by leaders throughout the Balkans in order to remove political opponents, receive international aid or position their countries favorably toward membership in international organizations. ${ }^{7}(2009,6)$

Reinforcing the need for transitional justice to take into account domestic concerns and input, Lambourne (2009) contends that for transitional justice to be truly transformative, i.e., meet its aspirational goals, local traditions and practices need to be part of it. $(31,33)$ Writing specifically about international and hybrid courts, which played a role in $\mathrm{BiH}$ and Kosovo, Stromseth (2011) cautions that unless these bodies are grounded domestically and partner with domestic institutions, these courts will act as "spaceships," specifically, they will arrive and depart without leaving any lasting effect. But, if these courts provide sufficient demonstration effects and engage in local capacity building, then they can have a positive impact. (172-78) In light of the importance the

\footnotetext{
${ }^{7}$ How this behavior impacted $\mathrm{BiH}$ and Kosovo will be discussed in Chapter Four.
} 
literature places on domestic involvement in choosing and implementing transitional justice, it is logical to ask of each of the cases how domestic selection and implementation or international imposition and management affect, in part, a mechanism's ability to impact the rule of law. While the literature has yet to provide definitive, empirical answers to these questions, this study applies these assumptions to $\mathrm{BiH}$, Kosovo, Colombia and Peru and offers analysis on the results within the respective country chapters.

\section{The Theoretical Boundaries of This Analysis}

Theoretically, transitional justice, as understood here, will follow the accepted parameters of the literature, namely it is a set of judicial and non-judicial mechanisms employed by governments to facilitate a political change (to peace) and address the effects of widespread political violence. (Olsen, Payne and Reiter 2010, 11; Serrano in Popovski \& Serrano 2012, 467) For this analysis, the mechanisms evaluated are limited to the primary mechanisms employed in most cases, principally domestic, hybrid and international trials, truth-telling, reparations, amnesties and lustration. ${ }^{8}$ While defining the theoretical boundaries of transitional justice is relatively straight-forward, the dependent variable in this analysis, the level of the rule of law, is more complicated.

It is acknowledged that like many concepts in political science, the rule of law is a contested concept, and it is difficult to measure. Yet, due to the importance of the rule of

\footnotetext{
${ }^{8}$ International courts are ad-hoc or permanent criminal tribunals established by the international community to try defendants outside of their home state. A modification of international trials can occur when international judges and lawyers work alongside domestic judicial officials in the country where the crimes occurred in courts known as hybrids, which often times use a mix of domestic and international law. Lastly, domestic criminal proceedings take place in the country where the crimes occurred, but differ from hybrid courts in that the former are staffed and adjudicated purely with domestic legal personnel.
} 
law, this challenge should not be abandoned. O'Donnell $(2004,32)$ labeled the rule of law an essential pillar in a democracy because it serves to protect civil and political rights. Therefore, understanding whether transitional justice promotes the development of the rule of law, and how, are important research questions.

Like its sister concept, democracy, there are a range of definitions for the rule of law, but they operate conceptually within a continuum. At one end, there is the procedural/formal definition, and at the other side of the spectrum is a definition that accepts the procedural dimensions but adds substantive elements to it. Returning to the former, according to Fuller, the law should have generality, publicity, prospectivity, intelligibility, consistency, practicability, stability and congruence. (Waldron in Fleming 2011, chap. 1) Describing his understanding of procedure, Fuller writes, "The term 'procedural' is, however, broadly appropriate as indicating that we are concerned, not with the substantive aims of legal rules, but with the ways in which a system of rules for governing human conduct must be constructed and administered if it is to be efficacious and at the same time remain what it purports to be." (Ibid, 8) Moreover, in addition to the equality of the law and its public nature, the procedural view has also been linked with the institutions, particularly the courts, required to carry-out and ensure that the law is general, equally applied, prospective, etc. (Bedner 2010, 68-69)

At the other end of the spectrum, the rule of law is conceived to be a more maximalist/substantive concept. While accepting the procedural requirements, proponents of a substantive conception argue that there must also be laws that protect human rights, group rights and social rights. (Ibid, 63-64) Stromseth, Wippman and Brooks (2006, 7071) view the debate as a difference between one side's satisfaction with a mere 
enunciation of what are the necessary rules, structures and processes as opposed to the other's insistence that the concept also entail the substance of what is to be protected. Aside from the academic literature, practitioners also generally understand the rule of law to be something within these two dimensions. For example, former UN Secretary General Kofi Annan $(2004,4)$, defined his organization's notion of the rule of law as entailing accountability of all before the law, insistence that all laws be public, that states have an independent judiciary and that domestic laws be consistent with international human rights. In keeping with the substantive side of the spectrum, a recent wave of scholarship has added to the substantive domain a change in societal behavior and attitudes. Reflecting this growing line of thinking, Bergman writes, "Rule of law transcends the competence of courts and the judicial branch. I claim it should be understood as a social equilibrium where the vast majority of citizens accept to be ruled most of the time by binding and general norms that have a high probability of compliance." $(2012,175)$ This scholar goes on to argue that in order for the majority of citizens to be compelled to obey the laws, the state must have the capacity to enforce them. Subsequently, when measuring the rule of law, citizens' compliance with the law should also be factored-in. (176-77) In light of these two domains, it is apparent that there is no one, generallyaccepted definition or measurement of the rule of law. According to Moller and Skaaning $(2014,26)$, when conducting research on the rule of law, a researcher's question(s) should dictate whether a procedural or substantive conception is utilized. Unfortunately, due to the paucity of studies examining the relationship between the rule of law and transitional justice, the literature does not explicitly state how and where transitional 
justice affects the rule of law, i.e., the procedural, substantive or both. Recognizing the dissonance between the two concepts one group of legal scholars opine,

Indeed, the question of whether and how accountability proceedings can contribute to strengthening domestic justice systems and to building the rule of law in post-conflict societies is surprisingly underanalyzed. For too long, the practical division of the fields of 'transitional justice' and 'rule of law reform' into two largely separate communities of scholars and practitioners has impeded efforts to explore systematically how accountability processes might, concretely, contribute to forward-looking rule of law reforms. (Stromseth, Wippman and Brooks 2006, 253)

In view of this separation, it is necessary to return to the transitional justice literature's assumptions about this relationship. At the procedural end, scholars expect transitional justice, particularly trials, to help enshrine within a society the equality of all before the law, one of the foundational elements of the procedural approach. (Olsen, Payne, and Reiter 2010, 133) On the other side of the conceptual spectrum, one of the most common arguments linking transitional justice and the rule of law is the transformational power and norm-changing abilities scholars and practitioners expect transitional justice to exert in a new democracy or post-conflict society.

According to one prominent transitional scholar, trials can not only act as deterrents, but they can also socialize new norms by publicly demonstrating what behavior is acceptable. (Sikkink 2011) Furthermore, “... what distinguishes transitional criminal measures is their attempt to instantiate and reinforce normative change." (Teitel 2000, 67) Consequently, it appears that the transitional justice literature has expectations that these processes will impact the procedural domain by at least promoting equality before the law, as well as the substantive, as exemplified by the Constructivists' assumptions of its ability to usher-in normative changes that would be reflected in the 
content of the law. Therefore, in determining which rule of law approach is appropriate for this project, it is evident that a substantive understanding will need to be utilized in order to assess both the procedural and norm-changing expectations within the literature. ${ }^{9}$

\section{Research Design}

As highlighted earlier, one of the methodological shortcomings in the transitional justice literature is the absence of an adequate number of cross-national comparative studies. (Thoms, Ron, and Paris 2010, 335) In an effort to fill this gap, this study utilizes a comparative approach that seeks to examine four countries across two regions. While large-N studies help establish trends and facilitate generalizability, the transitional justice literature also needs cross-national comparative work in order to help trace the impact of each transitional justice mechanism on the rule of law while also assessing the selection and implementation modalities. The aim of this methodology is to develop a mid-range theory about the relationship between transitional justice and the rule of law in postconflict states, as well as beginning to construct a theory of change.

\section{Cases}

The four cases selected, Bosnia and Herzegovina, Kosovo, Colombia and Peru, were chosen based upon this study's independent variable, namely the use of transitional justice in post-conflict environments. Choosing cross-regional cases is fraught with challenges, but identifying cases based upon the explanatory variable helps mitigate selection bias. (King, Keohane and Verba 1994, 149) Furthermore, all four of these countries are already identified and grouped within the literature as countries utilizing

\footnotetext{
${ }^{9}$ Please see Chapter Two for a full enunciation of how the rule of law is operationalized.
} 
transitional justice as part of or after an internal armed conflict. (Reiter, Olsen, and Payne 2013, 167-69) The decision was made not to include countries that transitioned from authoritarianism to democracy because circumstances in post-conflict cases, such as claims of self-determination, ethnic cleansing and internal displacements make drawing inferences more difficult if both types are combined. (Arthur 2009, 360)

While it is recognized that these four states are only a handful of the larger number of possible cases, these four countries were also chosen because time series data measuring the rule of law in each country is available, and there is sufficient variation in the independent variable as well. For instance, in Colombia and Peru, both of these countries utilized a range of transitional justice mechanisms, including trials, truth commissions, amnesties and reparations. Although more limited, $\mathrm{BiH}$ and Kosovo vary from Colombia and Peru in their use of transitional justice, notably in the international community's establishment of the International Criminal Tribunal for the Former Yugoslavia to serve as the primary mechanism in these Balkan countries. These two European cases are important not only because they allow measurement of international ad-hoc tribunals, but because both countries later established a range of domestic and hybrid courts to complement the work of the ICTY, and in the case of each, lustration was also used. Consequently, these four cases not only provide the much-needed crossregional comparison, but they cover the panoply of transitional justice mechanisms. ${ }^{10}$

It should also be noted that while transitional justice has largely run its course in Peru, the processes of transitional justice within Colombia, Kosovo and $\mathrm{BiH}$ are still

\footnotetext{
${ }^{10}$ Due to limited resources, in-country interviews were not conducted in Peru, and consequently, Peru will not be discussed separately. Peru, however, will be analyzed as part of the quantitative and concluding analyses based on available data.
} 
ongoing, although these efforts are also coming to a close. Despite these ongoing proceedings, and the accompanying empirical challenges this represents, the length of time since these countries initiated transitional justice, along with an adequate sample provided by each state over these many decades, allows ample data for analysis and conclusions to be drawn, however tentative they may be. Moreover, if scholars were to wait until all processes of transitional justice had run their course, the ability to theorize would be severely impeded since the use of transitional justice may last up to several decades. Furthermore, efforts to study transitional justice phenomena within functioning transitional justice processes is a practice accepted in the field as evidenced by the plethora of literature on countries such as Argentina, BiH and Colombia. Furthermore, possible lessons-learned from these countries' pasts could help inform their future decisions.

\section{Methodology}

While these cases afford opportunities for fruitful comparison, they also present methodological challenges. Neither the Most Similar System Design (MSSD) nor the Most Different System Design (MDSD) easily fit this empirical project. Although under the umbrella of post-conflict states, the differences in the role of the international community within the conflicts, and each country's unique level of development made employing an MSSD framework particularly troublesome. In relation to the MDSD, variations in the explanatory and outcome variables necessitate utilizing a different methodological approach. Consequently, in order to be able to best answer the aforementioned research questions, this study employs a mixed methodological approach, using both quantitative and qualitative techniques. 
One of the benefits of using qualitative analysis is its ability to identify causal mechanisms. (Munck and Snyder 2007, 20) Employing the framework provided by George and Bennett (2005), namely case study research with process tracing, the qualitative component of this project will examine the country cases using the same structure (same questions asked of each) as well as the same focus (mid-range typology). Because the rule of law is likely a result of multiple factors, using process tracing will help mitigate equifinality, and allow the researcher to link causes with outcomes. (Ibid) Moreover, process tracing allows this researcher to assess the degree of domestic influence and control national governments and citizens exerted over their transitional justice choices. In order to be able to capture some of the information necessary to answer these questions, qualitative data was gathered from in-country fieldwork in $\mathrm{BiH}$, Colombia and Kosovo from February to July 2016. This included approximately 60 interviews with former and current government officials, members of civil society and relevant in-country scholars.

Moreover, in an effort to provide a similar comparative framework in each of the qualitative country chapters, i.e., to ask the same questions of each, qualitative assessments are based on five end goals of rule of law reform. According to Kleinfeld, the rule of law is reflected by a government subordinate to the law, equality of all before the law, law and order exists, justice is efficient and human rights are protected. (2006, 36-46) Data on the performance of each country on these five domains comes from the researcher's own fieldwork and interviews, as well as publicly-available sources such as reports from the Organization for American States, the United Nations and European Union. 
This qualitative component is complemented by a quantitative section that includes descriptive statistics and multivariate regression analysis. Data for this latter section was taken from the World Bank's Worldwide Governance Indicators (WGI), which provides an aggregate, substantive rule of law score for each of these countries based on a wide variety of expert analyses and survey measurements. This time series data is important because it allows measurement of the rule of law before implementation of any transitional justice mechanism (except in $\mathrm{BiH}$ and Kosovo), the level of the rule of law at the time of implementation and its level five and ten years after its initiation. This not only increased the study's number of observations, but it is consistent with the measurement timelines used within the existing literature. For instance, Olsen, Payne, and Reiter $(2010,146)$ argue that it may take up to a decade after the initiation of transitional justice until changes in democracy and human rights are recognized. This assessment is shared by Haggard and Tiede (2014) who measured rule of law levels in post-conflict societies before, during and five to ten years after the cessation of violence. Equally important to the design of this study is the use of several control variables. Based upon the literature's findings, which will be discussed in more depth in Chapter Two, the level of gross domestic product per capita, a country's yearly percentage of Protestants and the total natural resource rents as a percentage of GDP were included in the regression model. (Moller and Skaaning 2014, 149)

\section{Structure of the Dissertation}

In light of the aims of this project, the dissertation is structured accordingly: Chapter Two explores the presence of systematic correlation between transitional justice and the rule of law using quantitative methodology. It discusses appropriate measures and 
presents findings from the descriptive and regression analyses. It concludes with a summary of the findings, paying attention to possible trends and patterns. The next part of the dissertation is divided by cases; Chapter Three examines Colombia's Justice and Peace Law of 2005; Chapter Four compares BiH's and Kosovo's experiences with transitional justice since 1993. These two chapters present the qualitative findings from the fieldwork, as well as trace the impact of various mechanisms of transitional justice on the rule of law, along with identifying powerful inhibiters in each country. The final chapter, Chapter Five, compares the findings of the four cases, including a more detailed analysis of Peru, discussing the overall theoretical implications and potential causal mechanisms. This chapter ends with a brief conclusion on remaining questions and possible areas of future inquiry. 


\section{Chapter 2 \\ Toward a Deeper Understanding of the Relationship \\ Between Transitional Justice \& the Rule of Law}

\section{Introduction}

As outlined in the previous chapter, both scholars and practitioners expect

transitional justice, particularly trials, to aid in the development of the rule of law. In fact, in a handful of studies, a relationship between these two variables was found (Sikkink 2011; Weiffen 2012), although their failure to control for other factors, inability to explain how this change occurred and their focus only on trials limits the explanatory power of these studies. Conversely, according to Haggard and Tiede (2014), the rule of law is largely path dependent in post-conflict states, and therefore, a change in the rule of law in countries like Colombia and $\mathrm{BiH}$ should not be expected.

In light of these assumptions and findings, this chapter sets out to accomplish the following: 1) Measure the rule of law in $\mathrm{BiH}$, Kosovo, Colombia and Peru during and after their respective periods of internal conflict to see if in fact the rule of law is path dependent; 2) Compare and contrast the level of the rule of law in these four states against other countries in their regions; 3) Determine whether the rule of law changed after the introduction of transitional justice in $\mathrm{BiH}$, Kosovo, Colombia and Peru; 4) If the rule of law did change, assess where this change occurred, i.e., in the procedural or substantive domains; 5) Test whether there is a correlation between transitional justice and the rule of law while controlling for other possible factors; and 6) Identify which model(s) of transitional justice (domestic, mixed or international) has an effect on the rule of law. However, before beginning to address each of these areas, it is helpful to first outline how the variables in this study are measured. 


\section{Measuring the Rule of Law}

Since the rule of law is a contested concept that operates on a continuum, there are very few data sets that measure both the procedural and substantive domains.

Fortunately, the Worldwide Governance Indicators (WGI) provide a comprehensive, yearly rule of law score for BiH, Kosovo, Colombia and Peru from 1996 to $2015 .^{11}$ These years are important because they cover the period before transitional justice was introduced in Peru and Colombia, and 1996 is only three years after the creation of the International Criminal Tribunal for the Former Yugoslavia (ICTY), which operated in both $\mathrm{BiH}$ and Kosovo. Unfortunately, data measuring the rule of law before the introduction of transitional justice in $\mathrm{BiH}$ and Kosovo is not available from the WGI. ${ }^{12}$ Overall, however, these four countries share nine sources that make-up the WGI rule of law score; Colombia and Peru share the same 18 sources and $\mathrm{BiH}$ and Kosovo share 11. This continuity aids in both cross-regional and within-region comparisons. The WGI yearly rule of law score, which ranges from -2.5 (weak rule of law) to 2.5 (strong rule of law), measures not only the fundamentals of the procedural and substantive domains, but it expands the latter to include public perceptions and measures of crime victimization. ${ }^{13}$ According to one legal scholar, "If citizens do not follow the law intended to protect their fellow citizens from assaults on their lives and properties, it means that the

\footnotetext{
${ }^{11}$ Measurement of the rule of law in Kosovo begins in 2003. Many of the other data sets either exclude Kosovo or do not begin measuring its rule of law until after it gained independence in 2008. For example, the World Justice Project has comprehensive indicators for the rule of law, but their data only begins in 2011 and does not include Kosovo.

${ }^{12}$ A qualitative baseline assessment of the rule of law before the introduction of transitional justice in both $\mathrm{BiH}$ and Kosovo is presented in Chapter Four.

${ }^{13}$ For a complete list of WGI sources and indicators for the rule of law, please see Appendix A.
} 
state fails to realise [sic] this function. It therefore seems correct to look at citizens' obedience to the law as well when trying to measure the elements of the rule of law..." (Bedner 2010, 56) The inclusion of data on behavior and perception is also important because it helps assess a society's acceptance of the law, which some argue is a necessary condition for the rule of law to take hold. For instance, Fukuyama $(2010,37)$ explains, "The normative dimension of the law-that is, people's belief that the law is fundamentally just and their subsequent willingness to abide by its rules-is key to the rule of law...if the gap between law and lived values is too large, the rule of law itself will not take hold." Consequently, the authors of the WGI explain their multi-layered indicator accordingly, "[the] rule of law captures perceptions of the extent to which agents have confidence in and abide by the rules of society, and in particular the quality of contract enforcement, property rights, the police, and the courts, as well as the likelihood of crime and violence."14

In addition to this explanation, it is important to highlight one other aspect of the WGI. While this dataset provides a yearly aggregate score for the rule of law, small annual changes should not be overestimated. Often, minor yearly fluctuations in scores occur because of changes in source indicators or fall within the prior years' margins of error. What the authors of the WGI claim their data does well is describe meaningful changes over time, such as over a decade or more. ${ }^{15}$ Subsequently, because of the

\footnotetext{
${ }^{14}$ Data for the WGI comes from surveys of households, firms, non-governmental organizations, commercial sources and the public sector. Most country estimates are based on at least 11 sources. The scores reported here are the aggregate scores.

${ }^{15}$ For a complete explanation of the WGI and its methodology, please refer to their website at http://info.worldbank.org/governance/wgi/index.aspx\#home.
} 
comprehensive nature of the WGI, it is an appropriate measurement of the rule of law for this study, and it is supported by more detailed qualitative analysis in the country chapters.

Moreover, various indicators within the WGI are broken down by year to help identify where the rule of law changed, i.e., in the procedural or substantive domains. For example, within this and other chapters, the Bertelsmann Transformation Index (BTI) and Political Terror Scale (PTS) are examined more closely because they encapsulate indicators along the rule of law spectrum, and they are both used for each of the four countries in this study. Within the BTI, its rule of law metric includes three useful indices. The independence of the judiciary (procedural), the prosecution of corrupt public officials (equality of all before the law, i.e., procedural) and the protection of civil rights (substantive). ${ }^{16}$ Additionally, the PTS, which measures the level of political violence within a country, can be extrapolated to represent the substantive changes expected, namely improvements in government and societal behavior.

\section{Measuring Transitional Justice}

Compared to the rule of law, measuring this study's independent variable is much simpler and less controversial. Transitional justice, as discussed in Chapter One, is the utilization of mechanisms by governments transitioning to democracy or peace that seek to address prior political violence while solidifying a political change. Although transitional justice has recently expanded to include such government actions as memorialization of the victims and bureaucratic reforms, the core mechanisms remain

\footnotetext{
${ }^{16}$ Although the BTI only begins to quantify their indices in 2006, this does not present a problem for this analysis since the most dramatic changes in $\mathrm{BiH}$, Colombia and Kosovo were only recorded after 2005.
} 
trials, truth commissions, lustration, reparations and amnesties (Arthur 2009, 326; Olsen, Payne, and Reiter 2010, 31), all of which were used to varying degrees in this study's four countries. Using these five mechanisms as the basis of analysis, I test the hypothesis that the manner in which transitional justice is chosen and implemented helps determine its impact on the rule of law, or more specifically, when societies choose and implement transitional justice rather than have it wholly imposed and executed by the international community, the development of the rule of law is greater. To that end, this analysis divides transitional justice into international, mixed and domestic categories.

The basis of this distinction closely follows the division used by the Transitional Justice Database Project, which is a database started at the University of Wisconsin that cataloged over 900 instances of trials, truth commissions, lustration, reparations and amnesties used worldwide from 1970 to 2007 based on an international, hybrid and domestic schema. ${ }^{17}$ According to one of the authors of this project, these three models were defined accordingly: international transitional justice occurs when trials take place in an international court; hybrid involves trials in a court where there are both domestic and international agents; and domestic transitional justice uses trials in domestic courts, i.e., in a court located in the country where the crimes occurred and operated by local judicial officials. $^{18}$

While this outline is helpful and generally accurate, it can be misleading when assessing the origination and implementation of transitional justice in countries like $\mathrm{BiH}$

\footnotetext{
${ }^{17}$ For a complete description and access to this Project's data, please see the Project's website at http://www.tjdbproject.com/.

${ }^{18}$ This explanation was provided in an email exchange the author had with Andy Reiter, August 11, 2016.
} 
and Kosovo, which both had extensive international oversight. For example, while lustration can be a purely domestic process, in the case of $\mathrm{BiH}$, the lustration of judges and prosecutors was at best a mixed form of transitional justice since the international community, particularly the Office of the High Representative, oversaw the process. Consequently, this study's categorization of transitional justice into international, mixed and domestic categories goes beyond the mere manner in which trials were adjudicated. The distinction of transitional justice based upon these three categories is assessed yearly, and the basis of this categorization is in accordance with the following logic.

A country's implementation of transitional justice is considered domestic when local residents and institutions inside of the country where the crimes occurred choose and implement all of the mechanisms used. Within this analysis, Colombia and Peru fit within this category since Peruvian and Colombian governments and societies selected and implemented the full range of transitional justice processes. This categorization does not, however, preclude limited international influence and financial support, although the degree to which these impact the selection and execution of transitional justice must not be the determining factors in mechanism selection and execution.

Those processes designated as international, which involves complete design and implementation by the international community, occurred in $\mathrm{BiH}$ and Kosovo as a result of the international community's imposition of the ICTY, along with the governing control exercised by the respective international oversight bodies within these Balkan states. Once domestic courts and local governments began to engage in things like trials and vetting, a mixed system developed in these latter two countries. A mixed system of transitional justice recognizes a balance between the international community's control 
and involvement and domestic design and operation of the various mechanisms. While these designations are not as neat as those used by the Database Project, changes to their method of categorization were necessary in order to truly capture the international community's role in all facets of transitional justice.

Data on which mechanisms each country utilized was compiled from the Transitional Justice Database Project and the researcher's own fieldwork. Table 2.1 identifies which mechanisms were or are being used in each country, and Appendix B presents the yearly categorization of transitional justice in each country. ${ }^{19}$

Table 2.1: Transitional Justice Mechanisms Used or In Use

\begin{tabular}{|c|c|c|c|c|c|}
\hline & Trials* & $\begin{array}{c}\text { Truth } \\
\text { Commission/Truth- } \\
\text { Telling }\end{array}$ & $\begin{array}{c}\text { Lustration } \\
\text { (Vetting) }\end{array}$ & Reparations & Amnesties \\
\hline BiH & $\checkmark$ & $\checkmark$ & $\checkmark$ & $\checkmark$ & \\
\hline Colombia & $\checkmark$ & $\checkmark$ & & $\checkmark$ & $\checkmark$ \\
\hline Kosovo & $\checkmark$ & & $\checkmark$ & $\checkmark$ & \\
\hline Peru & $\checkmark$ & $\checkmark$ & & $\checkmark$ & $\checkmark$ \\
\hline
\end{tabular}

*Whether a trial was international, hybrid or domestic is discussed in the country chapters.

Changes in the Rule of Law: Descriptive Analysis

\section{Rule of Law Levels}

Before introducing transitional justice to this analysis, it is first useful to get a baseline and take note of any general trends in the rule of law within $\mathrm{BiH}$, Kosovo, Colombia and Peru over the twenty years covered in this study. According to Figure 2.1

\footnotetext{
${ }^{19}$ For this analysis, truth commissions are temporary bodies commissioned by a government to investigate previous human rights abuses. Amnesties, reparations and lustration are all government actions that either respectively pardon or release previously convicted individuals, provide monetary or property restitution from the state to the victims and remove state officials from positions of authority due to their relationship with the prior regime. (Olsen, Payne \& Reiter 2010, 34-38)
} 
(below), three of the four countries experienced positive, sustained changes to their levels of the rule of law during (Colombia) or shortly after the cessation of their respective civil conflicts (BiH and Kosovo). Conversely, Peru's rule of law improved slightly for a few years following its violent and authoritarian era, but it then declined to levels lower than what it had during the tumultuous 1990s.

Figure 2.1: Yearly Rule of Law Scores 1996 to 2015

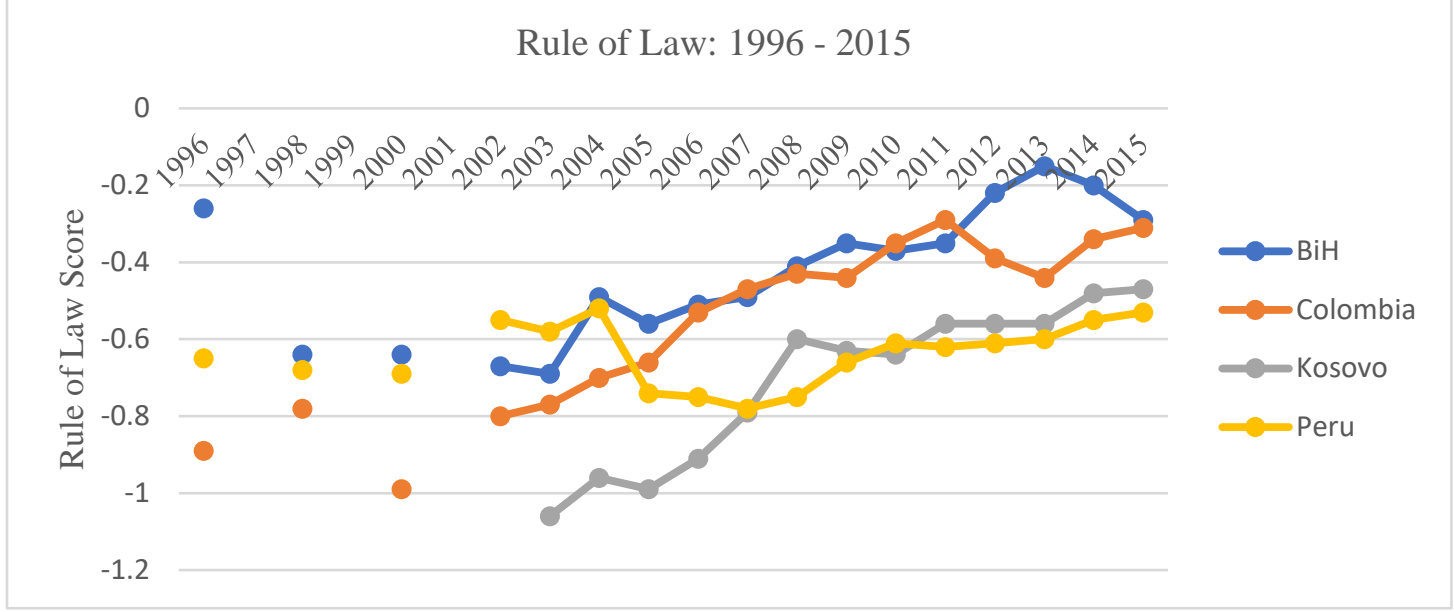

*Data is from the WGI.

The changes recorded in Colombia, $\mathrm{BiH}$ and Kosovo appear to question the pathdependency thesis put forward by Haggard and Tiede. For instance, despite Colombia still being a country with an ongoing armed conflict, albeit with significant progress achieved toward ending it, the rule of law improved during years of intense fighting.

In 2000, Colombia recorded its lowest level of the rule of law in the WGI, registering a disappointing -0.99. Early in the twenty-first century, the level of conflict in this Andean state was high with paramilitaries, guerillas, drug traffickers and the state all engaged in hostilities with one another. Yet, by 2002-03, modest improvements began, and by 2006, which is the year in which the demobilization of more than 30,000 paramilitaries concluded, the rule of law had improved by almost a half of a point. 
Despite some minor fluctuations since 2006, Colombia's rule of law has consistently improved, and by 2015, it had risen by 0.68 of a point from its 2000 -year low.

Moreover, while the WGI did not measure the rule of law before or during the conflicts in $\mathrm{BiH}$ and Kosovo, the rule of law improved following the cessation of violence in both countries. In $\mathrm{BiH}$ for example, the first comprehensive WGI measurement of the rule of law (1998) reflected a poor performing state as it relates to this element of society. ${ }^{20}$ Yet, within six years, real progress was realized, and by 2015 , $\mathrm{BiH}$ had reached an appreciably better level. Additionally, Kosovo, which may be considered the most politically unstable in the group because of uncertainties surrounding its political status from 1999 to 2008, also experienced improvements following the end of its $1998-99$ conflict, moving from a -1.06 to a -0.47 in only 12 years. ${ }^{21}$

Interestingly, Peru is the one country in this study that does support the pathdependency argument. ${ }^{22}$ The current level of the rule of law in Peru is relatively close to where it began in 1996. Consequently, the rule of law in this Andean nation appears fixed, although it should be noted that it dropped noticeably from 2005-08, which was a time when many of its transitional justice mechanisms were being used. Although this study's sample is much smaller than Haggard's and Tiede's examination of 47 countries, and therefore should not be overgeneralized, its findings are more optimistic. Principally, countries emerging from a period of intense internal violence can improve their rule of

\footnotetext{
${ }^{20}$ Although the WGI measured the rule of law in BiH in 1996, it was based on only two sources.

${ }^{21}$ As will be discussed in Chapter Four, Kosovo's independence in 2008 may have been a contributing factor for the increase in the rule of law as well as the extensive authority the international community exercised in this domain.

${ }^{22}$ Peru and BiH were both included in Haggard's and Tiede's study; Colombia and Kosovo were not.
} 
law, but as the trends demonstrate, progress is slow. Furthermore, Haggard and Tiede did not control for transitional justice. Consequently, it could be that the rule of law is not as deterministic in conflict countries that do use transitional justice as opposed to those countries that do not. A larger study of post-conflict states controlling for transitional justice needs to be executed to more fully test the path-dependency thesis.

\section{Comparing \& Contrasting}

Although these scores are meaningful in interpreting in-country changes, it is also helpful to compare these averages against other countries in Latin America and Southeastern Europe. Unfortunately, BiH, Colombia, Kosovo and Peru have been and remain some of the poorer performing countries in their respective regions as it relates to the rule of law. Therefore, improvements in their scores should be kept in context, and as will be discussed more thoroughly in the country chapters, perceptions and levels of the rule of law in $\mathrm{BiH}$, Colombia, Kosovo and Peru remain low.

Within Latin America, Colombia and Peru are regularly in the bottom third of nations when comparing their averages against other Latin American states. For instance, in 1996, according to the WGI's worldwide percentile ranking of states and regions, with $100 \%$ being the highest performing and $0 \%$ the lowest in terms of rule of law, the Latin American and Caribbean (LAC) region scored 50\%, but Colombia only 22\% and Peru 29\%. Approximately two decades later (2015), Colombia slowly caught-up, earning a 45 percentile rank (that year the LAC region's score was 49\%) while Peru remained behind at $35 \%$. To help illustrate this gap more tangibly, Table 2.2 illustrates the distance between LAC states generally considered to have the rule of law (Chile and Costa Rica) and states without it (Colombia and Peru). 
Table 2.2: Latin American Rule of Law Comparisons

\begin{tabular}{|c|c|c|c|c|}
\hline & Chile & Costa Rica & Colombia & Peru \\
\hline 1996 & 1.05 & 0.52 & -0.89 & -0.65 \\
\hline 2005 & 1.27 & 0.51 & -0.66 & -0.74 \\
\hline 2010 & 1.32 & 0.48 & -0.35 & -0.61 \\
\hline 2015 & 1.33 & 0.48 & -0.31 & -0.53 \\
\hline
\end{tabular}

*Data is from the WGI.

Not surprisingly, the two war-torn nations of $\mathrm{BiH}$ and Kosovo also lag behind their regional counterparts as illustrated in Table 2.3 below. Comparing their yearly rule of law levels to Slovenia and Croatia, both also former members of the ex-Yugoslavia, BiH's mean rule of law from 1996 to 2015 (-0.43) lags significantly behind Slovenia's average of 0.98 and Croatia's 0.04 . Kosovo is even further behind with a -0.71 mean. Regionally, both $\mathrm{BiH}$ and Kosovo also find themselves well below their neighbors in the WGI's Europe and Central Asia percentile rankings. For instance, in 2003, the region was at $61 \%$ while BiH's percentile ranking was $29 \%$ and Kosovo's was $16 \%$. However, 12 years later, improvements were noted; $\mathrm{BiH}$ had closed the gap registering $46 \%$ and Kosovo $37 \%$, which compared to the region's ranking of $67 \%$.

Table 2.3: Southeastern Europe Rule of Law Comparisons

\begin{tabular}{|c|c|c|c|c|}
\hline & Slovenia & Croatia & BiH & Kosovo \\
\hline 1996 & 1.05 & -0.61 & -0.26 & N/A \\
\hline 2005 & 0.86 & 0.09 & -0.56 & -0.99 \\
\hline 2010 & 0.98 & 0.17 & -0.37 & -0.64 \\
\hline 2015 & 0.95 & 0.20 & -0.29 & -0.47 \\
\hline
\end{tabular}

*Data is from the WGI. 


\section{The Rule of Law \& Transitional Justice}

Since yearly WGI scores are available before and after the implementation of transitional justice in Colombia and Peru, simple mean comparisons of the rule of law during these two stages can help indicate if there is a relationship between transitional justice and the rule of law. After calculating and comparing the mean rule of law scores for the years before and after the introduction of transitional justice, the results of which are presented in Table 2.4, the rule of law showed noticeable improvement in Colombia, while changes in Peru were negligible.

Table 2.4: Rule of Law Before \& After Initiating Transitional Justice (comparing means)

\begin{tabular}{|c|c|c|}
\hline & $\begin{array}{c}\text { Mean RoL before transitional } \\
\text { justice }\end{array}$ & $\begin{array}{c}\text { Mean RoL after initiating } \\
\text { transitional justice }\end{array}$ \\
\hline Colombia & -0.82 & -0.42 \\
\hline Peru & -0.67 & -0.63 \\
\hline
\end{tabular}

*Data is from the WGI.

In light of the fact that WGI rule of law scores are not available for $\mathrm{BiH}$ and Kosovo before the ICTY began its work in each of these two countries, it is useful to compare their averages based upon the type of transitional justice used. Comparing the means of these two countries, the average rule of law scores while international transitional justice was being used were significantly lower than when a mixed model was introduced. For example, in $\mathrm{BiH}$, its rule of law average from 1996 to 2004 was -0.57 , but after it transitioned to a mixed system in 2005 , its mean rule of law score increased to -0.35 during the period from 2005-2015. This same trend is seen in Kosovo where it averaged a rule of law score of -0.94 under a purely international model of transitional justice, but improved to a -0.56 under a mixed one. Figure 2.2 is a visual representation of the changes in means from international to a mixed model of 
transitional justice in these two Balkan countries. Moreover, according to separate

Independent-Samples $\mathrm{T}$ Tests run for both $\mathrm{BiH}$ and Kosovo, the differences in means are statistically significant at the 0.05 level. ${ }^{23}$

Figure 2.2: The Rule of Law with International and Mixed Models of Transitional Justice $\mathrm{BiH}$
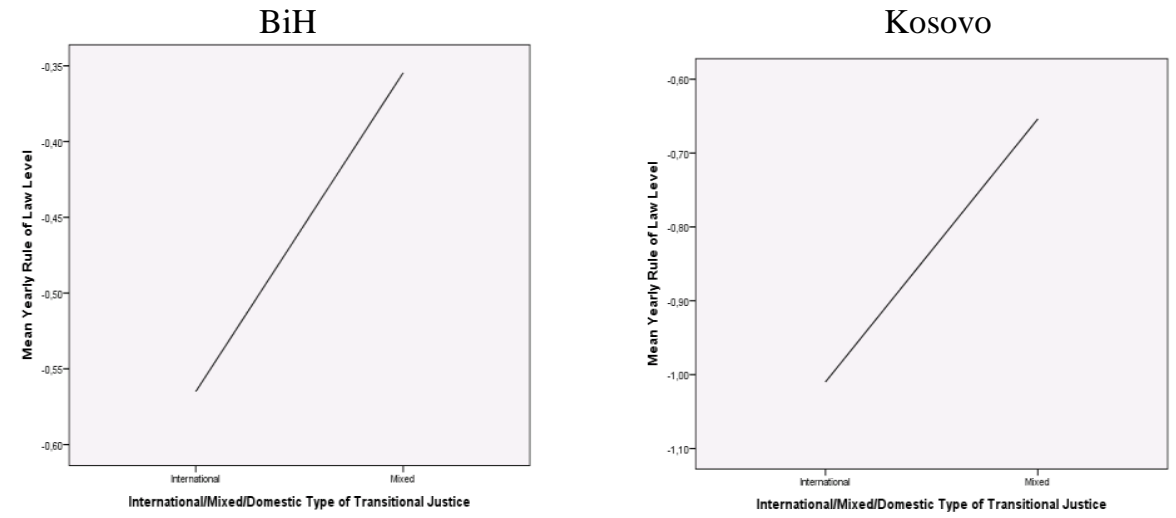

While this data is generally helpful in beginning to understand the relationship between these two variables, the general mean scores do not provide any degree of probability that these changes are due to transitional justice and not some other factor(s), nor do they indicate which components of the rule of law improved. For instance, does the use of trials, truth commissions, etc. impact the procedural domain or are the effects also seen in the substantive components of the rule of law? Looking at each country according to its development of a strong judiciary and ability to ensure the equality of all before the law (procedural), the BTS found improvements in Colombia, regression in $\mathrm{BiH}$ and no changes in either Kosovo or Peru, which are fully spelled-out in Table $2.5 .^{24}$

Since 2006, which is one year after the passage of the transitional justice legal framework for Colombia's paramilitaries, the independence of Colombia's judiciary

\footnotetext{
${ }^{23}$ Please see Appendix $\mathrm{C}$ for a full reporting of the $\mathrm{T}$ Tests results.

${ }^{24}$ Within the BTI, each indicator is ranked on a scale from 1 to 10 with 10 representing the highest performing institutions and protection of civil rights and 1 being the lowest.
} 
began to improve, going from a five to a seven between 2006 to 2015. According to the BTI 2016 Codebook, this improvement represents a change from a judiciary that was largely impaired by political influence and corruption (5) to one that is generally independent of political influence (7). ${ }^{25}$ Unfortunately, in the case of BiH, its judiciary has become more politicized and corrupt since 2006. Initially, the BTI scored BiH's judiciary a seven, but now its courts are heavily influenced by political actors and corrupt practices. In terms of BiH's and Colombia's performances in ensuring the equality of all before the law, Colombia improved slightly, and BiH's position remained the same.

Table 2.5: Changes in Procedural and Substantive Areas of the Rule of Law

\begin{tabular}{|c|c|c|c|c|c|c|}
\hline & IJ 2006 & IJ 2016 & PA 2006 & PA 2016 & CR 2006 & CR 2016 \\
\hline BiH & 7 & 5 & 6 & 6 & 6 & 7 \\
\hline Colombia & 6 & 7 & 5 & 6 & 4 & 6 \\
\hline Kosovo & $5^{(2010)}$ & 5 & 5 & 5 & 6 & 6 \\
\hline Peru & 6 & 6 & 6 & 6 & 6 & 6 \\
\hline
\end{tabular}

*IJ = Independent Judiciary; PA = Prosecution of office abuse; CR = Civil Rights

**Data is from the Bertelsmann Transformation Index

Turning to the substantive domain, the BTI's assessment of the protection of civil rights is similar to the procedural progression. Both Colombia and $\mathrm{BiH}$ improved in protecting civil rights, while Kosovo and Peru remained at the same levels. Most significantly, Colombia jumped from a four to a six, which represents a move from a country where rights were regularly violated "in practice" (4) to a state where these rights are now just "not properly respected" (6). As for the PTS, the general trends found in the

\footnotetext{
${ }^{25}$ For a complete enunciation of the BTI scale, please consult the 2016 BTI Codebook at www.btiproject.org/en/index/methodology.
} 
BTI are mirrored in the Political Terror Scale. For example, in 1996 through 2004, Colombia's level of political violence was high. The PTS gave Colombia its worst score (5), signifying that political violence was prevalent throughout the entire population; yet, after transitional justice was introduced in 2005, Colombia reduced its level of political violence, and by 2011, it earned a three. ${ }^{26}$ (Gibney, Cornett, Wood, Haschke and Arnon 2016)

In line with BiH's improvements in the BTI, this Balkan state was also recognized in the PTS for reducing its political violence. During the 1992-95 conflict, political violence was at its worst (5), but since this period, political violence has gradually receded. In 2015, BiH's political terror rating was the lowest possible (1), representing a state where torture is rare and the rule of law is secure. Moreover, according to the PTS, Kosovo has consistently had low levels of political violence since it first began measuring this in 2008 (a one or two), but in Peru, this form of state violence has fluctuated, moving back and forth between a two and three. (Ibid)

While this more detailed analysis is only the beginning of understanding the changes in the rule of law within these four countries, it does indicate that transitional justice may have helped develop both the procedural and substantive components of the rule of law, at least in Colombia. As the Colombia case illustrates, improvements were recorded in both the procedural (independence of the judiciary) and the substantive (markedly improved civil rights and less political violence). Equally significant is the fact that within this Andean nation, these changes occurred after the introduction of a variety

\footnotetext{
${ }^{26}$ A three, while not perfect, signifies there still may be political imprisonment, but political violence is less widespread. For a complete explanation of the PTS scale, please refer to its website at www.politicalterrorscale.org/.
} 
of domestically-generated and implemented transitional justice mechanisms. Bosnia's experience on the other hand is mixed. According to the BTI and PTS, BiH improved markedly in the substantive domain, yet regressed in the procedural. More specifically, Bosnia's judicial independence is deteriorating after an eight-year period of international transitional justice and oversight. This troubling trend is discussed in more depth in Chapter Four.

The ability to arrive at any generalized conclusions about Kosovo is difficult with the data at hand. The BTI only began measuring Kosovo during the period between 2008 to 2010, and the PTS also only started to record Kosovo's political violence in 2008. Yet, the limited BTI scores available for Kosovo do not show any changes in either the procedural or substantive areas of the rule of law. In fact, Kosovo's procedural scores (5) indicate that despite more than a decade of international oversight and ICTY involvement, Kosovo's judiciary remains heavily influenced by politics and corruption, and it is still unable to adequately prosecute public officials who abuse their positions of power. Although the BTI components remain fixed, the PTS does, however, regularly assign Kosovo its highest score, indicating a "secure rule of law" and the absence of political violence. Consequently, at this stage, we can theorize that Kosovo's ability to move from a -1.06 to -0.47 is in part related to the reduction in political violence. Yet, this cannot be the only factor propelling these gains. Subsequently, in Chapter Four, additional WGI indicators are more closely examined to identify where this shift occurred.

As for Peru, its fixed levels are reflective of the limited changes in its overall mean score. The stubbornness of the rule of law in Peru is, however, theoretically 
challenging since this country undertook a range of domestic mechanisms to address its political violence. Yet, despite more than 15 years of transitional mechanisms, the rule of law remains relatively the same. Neither the procedural nor the substantive domains improved (or deteriorated) as a result of its truth commission, trials or reparations. Recognizing that this chapter leaves many unanswered questions, which are better addressed in the qualitative analysis and country chapters, this section does, however, provide a general sense of the directionality of the rule of law. This element of human security did change in all four states in one direction or another, and in three of these four countries, the rule of law improved after the introduction of transitional justice. Furthermore, in both $\mathrm{BiH}$ and Kosovo, the rule of law noticeably improved once domestic institutions assumed some of the responsibility for formulating and executing transitional mechanisms. Colombia's improvement occurred under a purely domestic model, but Peru's regression while under domestic forms of transitional justice is puzzling. ${ }^{27}$

Although the overall analysis of the mean rule of law scores records significant changes, it is not clear if these changes were the result of transitional justice. For example, in each of these four countries, significant improvements in the country's GDP per capita were also recorded, and Protestantism increased in both Colombia and Peru, which according to the literature should produce positive change. In order to more accurately identify the effect of transitional justice, a mixed-effects regression model was run controlling for other possible causes in improvements to the rule of law.

\footnotetext{
${ }^{27}$ Peru is discussed in the final chapter.
} 


\section{Test of Correlation}

\section{Control Variables}

Within the rule of law literature, Moller and Skaaning $(2014,149)$ identified seven factors that the field has recognized as affecting the rule of law. Socio-economic development, country size, ethnic fractionalization, natural resource abundance, common law system, colonial heritage and dominant religion are all variables various scholars have utilized to describe a country's level of the rule of law. Yet, after Moller and Skaaning ran regression analysis, a country's level of socio-economic development, natural resources and number of Protestants were the only variables that proved statistically significant.

Moller and Skaaning (153) opine that socio-economic levels are important because development encourages individuals to demand the accompanying legal protections for the higher self-expression values that accompany socio-economic development. Additionally, a state's level of natural resources matters because of its effect on patron-client relations, i.e., the higher the level of natural resources the lower the level of the rule of law, and it is expected that a large number of Protestants is positively correlated to the rule of law, much like the relationship theorized between Protestantism and democracy. (Weber [1930] 2002)

Based upon these findings, this study controls for socio-economic development, as reflected in the level of GDP per capita, as well as levels of natural resources, which is measured by total natural resources rents as a percentage of GDP. Finally, a country's percentage of Protestants is taken from the yearly U.S. Department of State Religious Freedom Report. Data for the two previous controls comes from the annual World Bank 
list of economic indicators. (See Appendix D for a description and list of sources for all variables.)

\section{Regression Analysis}

Data for the regression analysis is taken from the WGI's aggregate yearly rule of law score from 1996 to 2015, as well as my coding of the type of transitional justice used in each of the four countries (Appendix B).$^{28}$ Although the WGI begins allocating scores for the rule of law in 1996, data for some of the early years (1997, 1999 and 2001) is missing, resulting in an unbalanced pool. Moreover, as is common with panel, crosssectional time series data, a simple linear model could not be applied due to potential problems with heteroscedasticity and serial autocorrelation. Consequently, a mixedeffects model was chosen to test the hypothesized impact of transitional justice.

A mixed-effects model is the most appropriate regression tool for this study since the data is the result of both random and fixed effects. A general linear model is not optimal in this study because the yearly measurements are correlated. Mixed-effects models are often used when measurements are taken repeatedly of the same subject, i.e., the same country over twenty years. Consequently, "Though the fixed effect is the primary interest in most studies or experiments, it is necessary to adjust for the covariance structure of the data. The adjustment made in procedures like GLMUnivariate is often not appropriate because it assumes independence of the data. The

\footnotetext{
${ }^{28}$ For example, the categorical variable transitional justice was coded 1 if the model was international, 2 if mixed and 3 for domestic. While these cases meet the post-conflict criteria and provide meaningful comparisons, it is acknowledged that within the regression analysis there are limitations because two of these countries do not vary on the model of transitional justice used (Colombia and Peru).
} 
MIXED procedure solves these problems by providing the tools necessary to estimate fixed and random effects in one model." (SPSS 2005, 1)

Based upon the literature, the following model was constructed:

$\mathrm{Y}=\mathrm{a}+\beta \mathrm{j}+\mathrm{bTJ}+\mathrm{bGDP}+\mathrm{bResources}+\mathrm{bProtestants}+\beta \mathrm{j}$ Time $+\mathrm{e}$

Where $\mathrm{Y}$ is a country's level of the rule of law, a is a general intercept of the models, $\beta \mathrm{j}$ represents the intercept of country j, bTJ identifies the model of transitional justice, bGDP represents a country's yearly GDP per capita, bResources is a country's total natural resources rents as a percentage of its yearly GDP, bProtestants represents a country's yearly percentage of Protestants, $\beta \mathrm{j}$ Time is year for country $\mathrm{j}$ (from 1996 to 2015 or 1 through 20) and e is the error term. ${ }^{29}$ (Note: b identifies the coefficients for the fixed effect and $\beta$ represents the coefficients for the random effect; $\mathrm{j}=(1, \mathrm{~N})$ where $\mathrm{N}$ is the total number of countries.)

Before conducting the regression analysis, a correlation matrix for this study's continuous variables was created showing the Pearson's $r$ scores, which range from -1 (strong negative correlation) to 1 (strong positive correlation). The matrix identifies that there is a strong positive correlation between the rule of law and GDP per capita (Pearson's $r$ of 0.54 ), but a much weaker positive association between the dependent variable and natural resource rents (0.06) and the level of Protestants (0.034). While this does not identify cause or effect, it is consistent with the control variables recommended by Moller and Skaaning. Additionally, the matrix identifies a strong degree of collinearity among several of the control variables. For instance, the correlations between natural

\footnotetext{
${ }^{29}$ The author wishes to thank Sebastian Rangel at the National University in Bogota, Colombia for his helpful advice and suggestions in this part of the analysis.
} 
resources rents and the level of Protestants and GDP per capita are 0.79 and 0.64 respectively. The level of Protestants is also strongly correlated with GDP per capita (0.50). In light of these relationships, models were run excluding some of the control variables.

Returning to the original model, none of the types of transitional justice, i.e., international, mixed or domestic, were statistically significant. Moreover, from the control variables, only GDP per capita and level of natural resources were found to be correlated to the rule of law, the former was positively and the latter negatively associated. ${ }^{30}$ The absence of a relationship between this study's independent and dependent variables was confirmed when the model was run without any of the control variables. However, when the type of transitional justice in Kosovo was coded differently, the international and mixed models did prove to be statistically significant. ${ }^{31}$

More specifically, under an international model, a country's rule of law would increase by 0.29 , and with a mixed approach the rule of law would rise by 0.26 , compared to if only domestic mechanisms were employed. The relationship with GDP per capita and the rule of law was minimal in this second test, and both natural resources and Protestants turned out to be statistically insignificant with P-values well above .05. The results from both tests are reported below in Table 2.6. ${ }^{32}$

\footnotetext{
${ }^{30}$ When the model was run with only the three control variables, GDP per capita and level of Protestants were statistically significant.

${ }^{31}$ Instead of Kosovo's mixed model beginning in 2008, it can be argued that it began much earlier since hybrid trials were used as early as 2000. The second test used data where Kosovo had three fewer years of international and three more years under a mixed model.

${ }^{32}$ While R produced several Goodness of Fit statistics, such as AIC, BIC and Loglik, these numbers are not as useful as the residual charts. It is difficult to compare the two models using these Goodness of Fit statistics since two of the variables in the original model are not statistically significant.
} 
Table 2.6: Mixed-Effects Regression Results

\begin{tabular}{lllll} 
& \multicolumn{2}{c}{ Test $1(\mathrm{~N}=45)$} & \multicolumn{2}{c}{ Test $2(\mathrm{~N}=39)$} \\
Intercept & -0.5636882 & 0.0070 & Coefficient & P-value \\
ITJ & 0.1415024 & 0.2007 & -0.6197002 & 0.0029 \\
MTJ & 0.1086073 & 0.2397 & 0.2949539 & 0.0076 \\
GDP & 0.0000797 & 0.0020 & 0.2642796 & 0.0068 \\
NRR & -0.0104602 & 0.0308 & 0.0000514 & 0.0470 \\
PTS & -0.0148472 & 0.2216 & 0.0011868 & 0.8279 \\
\hline
\end{tabular}

ITJ = International Transitional Justice; MTJ = Mixed Transitional Justice; GDP = GDP per capita; NRR = Natural Resource Rents as a percentage of GDP; PTS = Yearly percentage of Protestants *According to the residual results, the best models were those that did not include the level of Protestants due to the high collinearity among the control variables, as outlined on pages 43-44. In all the models run, only GDP per capita was statistically significant with the rule of law.

*Entries are unstandardized (or standardized) regression coefficients, computed using the $\mathrm{R}$ statistical software.

\section{Conclusion}

The univariate statistical analysis presented in this chapter appears somewhat at odds with the regression estimates, which take into account other factors. For instance, when comparing means in Colombia, which employed a wholly domestic approach to transitional justice, there was a noticeable improvement in the rule of law after transitional justice was introduced in 2005, rising from -0.66 in 2005 to -0.31 in 2015.

Yet, according to the regression results, the domestic model is not statistically significant. This finding is, however, consistent with the experience in Peru. Despite utilizing an array of domestic mechanisms, such as a truth commission, trials, reparations and amnesties, its rule of law improved very little, and in fact, it declined noticeably while some of these policies were being used.

In $\mathrm{BiH}$ and Kosovo, which are two cases that moved from an international to a mixed form of transitional justice, one set of regression results finds neither model statistically significant, but in another, both models were positively correlated to the rule of law. These findings are, however, at odds with the comparison in means, the 
differences of which were statistically significant, and the histogram shown in Figure 2.3 below, which clearly indicates better rule of law scores under a mixed or domestic model. Combined, both $\mathrm{BiH}$ and Kosovo experienced 15 years of internationally-led transitional justice. During this time, the yearly rule of law levels in both states remained relatively constant. Yet, after a shift to a hybrid system in both countries, which allowed some domestic input into the design and implementation of things like trials, the rule of law increased noticeably when compared to their international periods, particularly in $\mathrm{BiH}$, moving from a -0.57 to -0.35 .

\section{Figure 2.3: Rule of Law Scores \& Models of Transitional Justice}

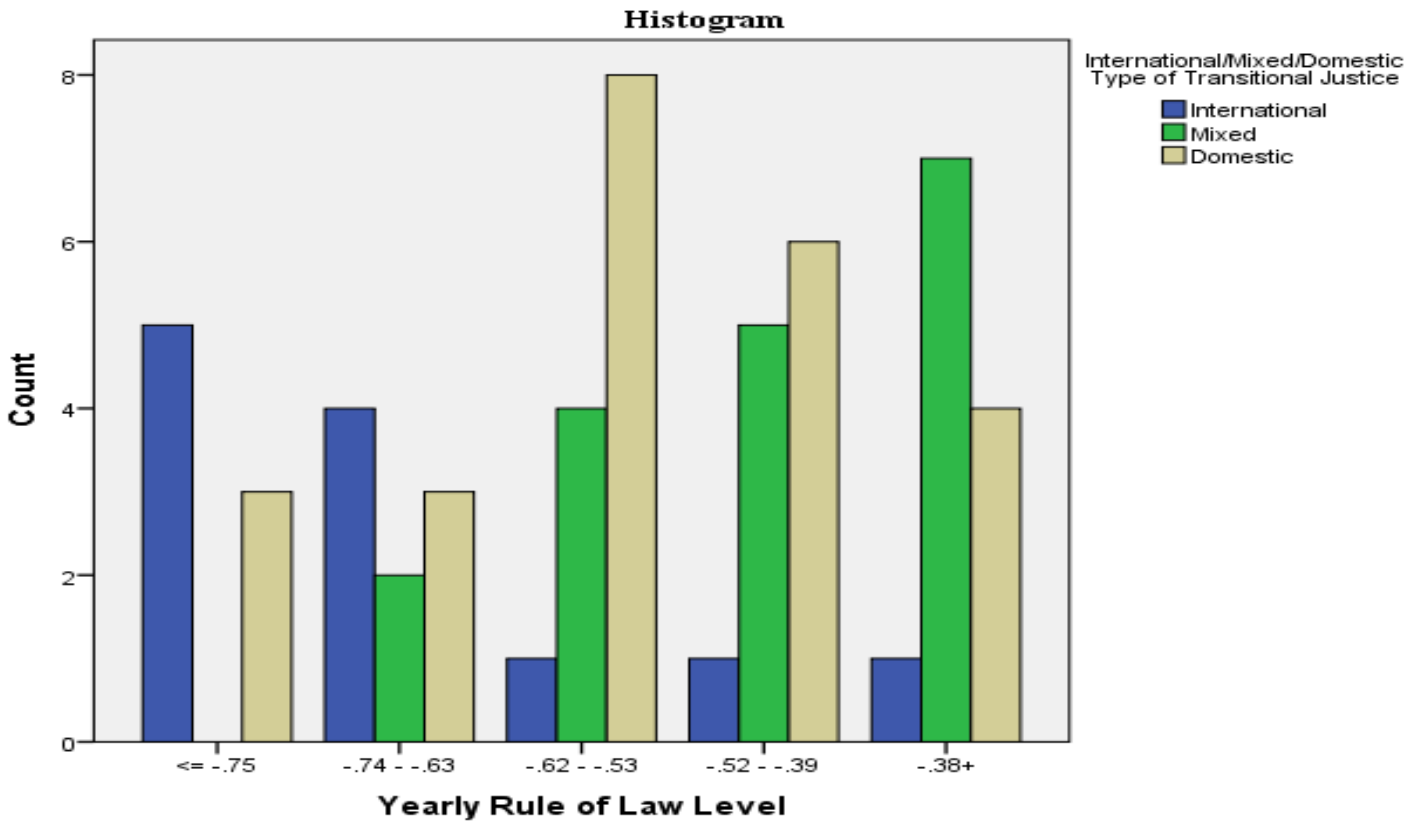

*Data is from the WGI, and it represents all four countries in this analysis.

Although the statistical results may be at odds, the trajectory of the rule of law in three countries does question the generalizability of the path dependency thesis. More specifically, although previous scholarship argued that the rule of law is relatively stable in post-conflict states, three of the four countries in this study experienced sustained 
improvements to their rule of law levels following the cessation of violence. This finding is important. If the rule of law does not change five to ten years after the end of civil conflict, as Haggard and Tiede argue, then studying the impact of transitional justice on the rule of law in post-conflict states is futile. As illustrated here, the rule of law does change five and ten years after the termination of a conflict. It is important to remember that the aforementioned study did not control for transitional justice in the 47 states it examined, and the path dependency thesis should not be abandoned altogether. As noted earlier, a more comprehensive study of post-conflict states, controlling for the use of transitional justice, needs to be developed to more fully test this thesis.

Finally, although the improvements in mean rule of law scores in Colombia, BiH and Kosovo coincided with the use of transitional justice, these tentative findings should not be overstated. Other factors, such as the presence of international police and peacekeepers in $\mathrm{BiH}$ and Kosovo, also precipitated change. But, there are at least indications that transitional justice may be partially responsible for influencing the full rule of law spectrum. In order to get a clearer picture regarding the relationship of transitional justice and the rule of law, the results from the qualitative analysis are described in Chapters Three and Four. 


\section{Chapter 3 \\ Colombia: The Introduction of Truth, Justice and Reparations}

Introduction

For more than half a century, Colombia has been plagued by incessant civil conflict that has been fueled by the struggle for power, land and drugs. Entwined within this mix has been the state, right-wing paramilitaries, leftist guerillas and criminal organizations. After 53 years of internal strife, 267,225 individuals have been killed, most of them civilians, over seven million have been displaced and 8,376,463 victims have registered with the state. ${ }^{33}$ (Victims Unit) Fortunately, the flood of violence is beginning to abate. On November 24, 2016, the Government of Colombia (GoC) and the largest guerilla group the FARC (Revolutionary Armed Forces of Colombia) signed, for a second and final time, an historic peace agreement after four exhausting years of negotiations in Havana, Cuba. ${ }^{34}$ Moreover, the second remaining guerilla group, the National Liberation Army (ELN) began its own round of peace negotiations with the GoC on February 7, 2017.

Yet, before these recent developments, Colombia was no stranger to peace agreements and large-scale demobilizations. From 1989 to 1994, five leftist guerilla groups laid down their arms and reintegrated into society through a series of relatively successful disarmament, demobilization and reintegration (DDR) agreements. ${ }^{35}$

\footnotetext{
${ }^{33}$ Official GoC data on the number of victims can be accessed at: http://rni.unidadvictimas.gov.co/RUV

${ }^{34}$ Colombian voters rejected the first peace agreement in October 2016. A revised agreement was not put before voters, but it was approved by Congress on November 30, 2016.

${ }^{35}$ During this time, peace agreements were reached with the Movimiento 19 de Abril (M-19), Movimiento Armado Quintin Lame, Ejercito Popular de Liberacion, Partido Revolucionario de los Trabajoadores and Corriente de Renovacion Socialista.
} 
Furthermore, between 2003 to 2006, more than 31,000 paramilitaries demobilized, and as part of this process, Colombia launched its first serious attempt at utilizing an array of transitional justice mechanisms that promised to deliver truth, justice, reparations and non-repetition of conflict crimes.

The foundation of Colombia's first real attempt at transitional justice is Law 975 of 2005, aka the Justice and Peace Law, which was a turning point in Colombia's transitional jurisprudence and recognition of the conflict victims. Law 975 has also helped shape the peace agreement with the FARC by ensuring that victims remain central to the peace process, and it will most likely influence any potential agreement with the ELN. Consequently, in light of the importance of this early wave of transitional justice, Chapter Three examines Law 975 and other related transitional policies as they relate to their impact on the development of the rule of law in Colombia. It is recognized that Colombia's conflict with the ELN is still ongoing while negotiations take place with this guerilla group, and one dose of transitional justice within this unsettled environment is likely insufficient to produce a tidal wave of change. Yet, because more than 50,000 illegal combatants demobilized, special courts were created and a series of truth-telling and reparation initiatives were launched, some effects should be seen. ${ }^{36}$

Based upon the statistical analysis from the previous chapter, there is evidence that Colombia's rule of law did show modest improvements in the decade since passage of the Justice and Peace Law. Recall that from 1996 to 2004, Colombia's mean rule of

\footnotetext{
${ }^{36}$ In total, approximately 56,000 illegal combatants demobilized under the Justice and Peace framework, including a little more than 24,000 guerillas. (MOJ 2015, 3) The exact number of paramilitaries before demobilization began is unclear since many criminals demobilized with paramilitary units to take advantage of the provisions of the Justice and Peace process.
} 
law within the WGI was a -0.82; yet, within the 10 years during which time Law 975 has been in effect, Colombia has averaged a -0.42 , and it recently recorded a -0.31 in 2015 . Since 2003, which is the year demobilizations began with the paramilitaries, aka the United Self-Defense Forces of Colombia (AUC), the rule of law has been on a consistent and steady rise, as illustrated in Figure 3.1 below.

\section{Figure 3.1: Colombia's Yearly Level of the Rule of Law}

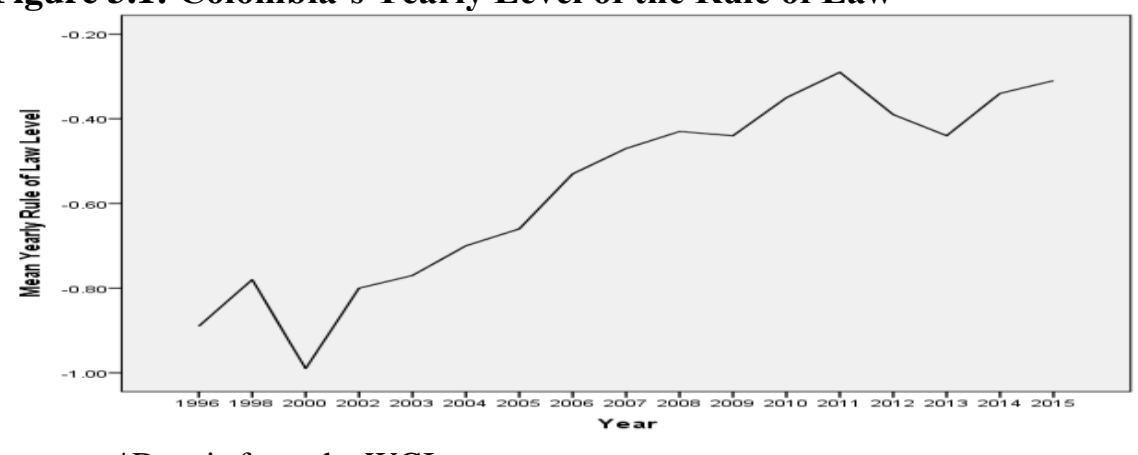

*Data is from the WGI.

Moreover, Colombia's improvement has been in both the procedural and substantive domains. According to the BTI, the independence of Colombia's judiciary has improved, there is less impunity for those who abuse their positions of power and the protection of civil rights has increased. Additionally, Colombia went from a country where political violence was commonplace to a society where political assassinations, police brutality, etc. are less frequent. (Gibney et al. 2016) While these are welcomed changes, how and why did they occur? According to the regression results from Chapter Two, a purely domestic model of transitional justice does not have a statistically significant relationship with the rule of law. Yet, Colombia's rule of law grew appreciably after it launched its transitional justice programs in 2005, improving from a -0.66 (2005) to a -0.31 in 2015. 
Although transitional justice helped, it was not the only factor that facilitated change. Colombia's GDP per-capita and level of Protestants also grew noticeably during this time, which are both positively correlated to the rule of law, and other events, such as an improvement in the overall conflict need to be taken into account. Furthermore, it is important to remember that much like the other three countries in this study, Colombia has not yet reached a satisfactory level of the rule of law, despite recent gains. By comparison, in other parts of South America in 2015, the WGI assigned a rule of law score of 1.33 to Chile and 0.68 to Uruguay, whereas Colombia scored a -0.31. In fact, part of the reason transitional justice has not been able to effect further change is the failure of the Colombian government to fully implement the transitional policies it promised, as well as its inability to establish an enduring governing presence in former conflict regions, problems that will be discussed more fully throughout this chapter. Consequently, there remains much room for improvement, and the rule of law is not a consolidated feature in this Andean nation. For this end-state to be realized, the overall conflict will need to come to an end, the government must take seriously recapturing and governing former conflict-affected regions, and endemic corruption must be curtailed. Without changes, any new wave of transitional justice will also likely fail to help produce more meaningful reform.

In order to help assess the impact of this first wave of transitional justice and the state of the rule of law in Colombia, 20 interviews were conducted in-country from February-April 2016 and in January 2017. These interviews were conducted with current or former GoC officials involved in the design and implementation of Law 975, including a magistrate in one of the special tribunals and officials in the Fiscalia (Attorney 
General's Office). Moreover, members of the government that are involved in the financial, physical and psychosocial reparations to paramilitary victims were also interviewed. Based upon the interviewee's position, a series of questions regarding the general state of the rule of law, along with specific questions surrounding the design and implementation of the Justice and Peace Law were asked of each individual (see Appendix E for a list of general questions). ${ }^{37}$

To help fill-in some of the informational gaps not covered by the interviews, all 21 half-yearly or quarterly reports of the Organization of American States Mission to Support the Peace Process in Colombia (MAPP/OEA, Spanish acronym; hereafter MAPP) were carefully evaluated. These reports provide an impartial, international evaluation of the implementation of Law 975 and transitional justice in general. The MAPP was established in 2004 by agreement between the Organization of American States (OAS) and the GoC to help oversee the demobilization of the paramilitaries, and its mandate has grown to encompass all aspects of the former and current peace processes. These reports are particularly useful in a comparative study since most of the documents report on the same elements of the peace process over-time. Moreover, to help assess Colombia's and the international community's involvement in the design, selection and implementation of these transitional mechanisms, more than 90 international news articles from 2002-2006 were reviewed. These articles include

\footnotetext{
${ }^{37}$ Due to the sensitivity of the previous and ongoing peace processes, most interviewees asked to remain anonymous.
} 
interviews with both government and paramilitary negotiators, congressional

representatives and views from the international community. ${ }^{38}$

Currently, certain aspects of Law 975 continue to be implemented, although most of these mechanisms are coming to a close. For instance, initiatives for truth-telling under Justice and Peace were finalized in 2013, and most of the trials that will be held for demobilized paramilitaries have at least completed the first judicial stage. Unfortunately, much remains to be done to fully dispense with the reparations for this set of victims, and in light of this evolving and ongoing process any conclusions drawn will be tentative. Yet, after 11 years of implementation and a new wave of transitional justice set to get underway for the FARC and state officials, now is an appropriate time to take stock of Colombia's first important experience with transitional justice. These findings could not only help conclude Justice and Peace, but they can also serve as valuable lessons for currently-evolving transitional policies, both in Colombia and in other conflict-affected states.

To that end, this chapter will limit its study to only those transitional justice mechanisms designed and implemented as part of Law 975 (2005) and continue through 2012 when Colombia’s Legal Framework for Peace and Law 1592 were approved. Although these newer transitional justice policies, which include elements such as administrative reparations and restitution of land, were introduced for a larger pool of victims, these post-975 mechanisms also cover paramilitary victims and are therefore connected to this overall initial wave of transitional justice. This chapter will not attempt

\footnotetext{
${ }^{38}$ Articles related to "Colombia and paramilitaries" from 2002-2006 were reviewed using the LatinNews database.
} 
to analyze the unfolding transitional justice formula currently being assembled for the FARC and agents of the state. Not only is the scope of these new mechanisms greater, but they also seek to provide truth and justice in different ways.

Therefore, a logical beginning and termination point to evaluate the rule of law is immediately before 2005 through 2015, which is one year before the peace agreement with the FARC was signed and any new transitional justice mechanism began to be implemented. To help trace this path, the analysis is organized accordingly: the following section outlines the institutional edifice and type of transitional justice erected by the Justice and Peace Law and its related transitional initiatives; the next section assesses the design of this transitional framework, paying attention to the manner in which these policies were created and implemented; the third section evaluates the implementation of this wave of transitional justice against its ability to deliver change within the five characteristics of the rule of law outlined in Chapter One; and finally, the chapter concludes with some final observations and Colombia-specific recommendations.

\section{The Introduction of Truth, Justice \& Reparations}

Up until 2005, Colombia's peace processes were largely disarmament, demobilization and reintegration agreements between the executive branch and rebel groups. The government demanded full demobilization in return for amnesties or pardons with opportunities for political participation. Moreover, the negotiations that led to these DDR accords were done behind closed doors with little to no international, civil society or victim input. (Carrillo 2009,138-41) From 1989 to 1994, this model was successful in demobilizing approximately 5,000 combatants, and launched the political careers of a handful of ex-guerilla leaders. 
According to one of these former guerrillas, now turned Colombian Senator, these DDR approaches were generally successful because Colombian society supported some of their causes, such as fixing a broken political system and alleviating poverty, and the opportunity for political participation provided an outlet for the political angst of these rebels. ${ }^{39}$ Although there was some sympathy, as reflected in the political success of groups like M-19 (Movimiento 19 de Abril), there were other domestic and international factors that explain why this model was chosen. For example, Colombian law did not require the type of retributive and restorative proceedings now enshrined in the country's legal code, and human rights had not yet become a galvanizing issue within the polity or for international donors. (Guaqueta 2007, 425) Moreover, there was no international criminal court to pressure Colombia to do more, and international attention was focused on other conflict-affected regions like the former Yugoslavia.

Although there is no WGI data for this period, the first recorded measurement from Colombia in 1996 notes a low level of the rule of law (-0.89), which only continued to decline until 2002. In fact, during the 1980s-1990s, Colombia was a country beset by drug violence led by powerful cartels, such as the Medellin Cartel of Pablo Escobar, rampant kidnappings, car bombings, assassinations and guerilla-paramilitary conflict. To illustrate the state of lawlessness at this time, three presidential candidates were assassinated in the lead-up to the 1990 presidential election, and the number of annual civilian deaths caused by the conflict increased dramatically during the 1990s, going from approximately 2,000 at the start of the decade to approximately 6,000 in 1999 .

\footnotetext{
${ }^{39}$ Senator Antonio Navarro Wolff, interview, March 2, 2016, Bogota, Colombia.
} 
(Pachico 2015 and Historical Memory Group) Consequently, it is fair to conclude that Colombia's use of amnesties with political participation did little to improve the rule of law despite having domestic support and being domestically implemented. Any positive effects these amnesties may have had were negated by more powerful episodes of violence. The rule of law during this period was a foreign concept for most Colombians, and while quantitative estimates are not available, Colombia was likely at its lowest point during this time of general lawlessness.

After a failed attempt at peace with the FARC under President Andres Pastrana, his successor, President Alvaro Uribe (2002-10), prioritized peace with the country's paramilitaries. The paramilitaries initially emerged as self-defense forces for rural land owners during the 1960s as a way to protect cattle farmers and other rural elites from the guerillas. Due to a weak state and anemic military and police, GoC Decrees 3398 (1965) and 48 (1968) legalized these civilian self-defense groups. Describing their role, one scholar notes, "Although the initial response was to provide security for landowners in the area, the paramilitary forces assumed a much larger role within the community, ultimately taking over the essential roles of the state-providing security and mediating conflicts, but also building infrastructure, establishing schools, and offering health care." (Tate 2009, 126)

By the 1980s, many of these paramilitary forces were enmeshed in the drug trade, and occasionally served as the private armies for Colombia's drug cartels. A decade later, the paramilitaries had expanded their reach, operating in 26 of Colombia's 32 departments, and they had become synonymous with crime and political violence. According to the Colombian Commission of Jurists, by 1999, $78 \%$ of all non-combatant 
deaths were attributable to the paramilitaries, while the guerillas were responsible for $20 \%$ and the state $2 \%$. (Aviles 2006, 403) Although the paramilitaries were formally outlawed in 1989 due their growing criminal activities, these groups continued to act with impunity.

In 1997, the strength of the paramilitaries increased when most of these disparate groups consolidated under the federated banner of the United Self-Defense Forces of Colombia (AUC), and they benefited from the extinction of the former Medellin and Cali drug cartels. Under this collective, the intensity and severity of the paramilitaries' criminal behavior increased. For instance, the Colombian Ministry of Justice estimates that the majority of the more than 370,000 crimes recorded during the Justice and Peace process occurred between 1999 to 2002. (Colombian Ministry of Justice 2015, 3, 8; hereafter MOJ) Moreover, as of 2002, which is when the International Criminal Court's (ICC) jurisdiction for some crimes in Colombia began, this court's Office of the Prosecutor noted that there is a "reasonable basis" to conclude that the AUC was responsible for crimes against humanity, which includes murder, forced displacement, deprivation of physical liberty, torture and rape. ${ }^{40}$ (International Criminal Court 2012, 23; hereafter ICC)

Consequently, when President Uribe opened a formal dialogue with the AUC in 2002, he faced an illegal-armed group, the basis of which was at one time legal, yet it had morphed into a force responsible for violations of international humanitarian and human rights law, along with an entity heavily engaged in drug trafficking. Despite these crimes,

\footnotetext{
${ }^{40}$ The ICC's Office of the Prosecutor also noted that the FARC and ELN were responsible for these same crimes. The ICC's jurisdiction for war crimes began in 2009, three years after the demobilization of the paramilitaries.
} 
the Uribe Administration initially offered the AUC a DDR-style agreement similar to what had been used throughout the 1990s, but after a lengthy domestic process of negotiation and compromise, the Justice and Peace Law was passed by the Colombian Congress in June of 2005.

Law 975 emerged as a radical change in Colombia's transitional jurisprudence. According to the law, those demobilized that committed serious crimes, either paramilitaries or individual guerillas, are to take part in a multi-stage judicial process that begins with the Colombian High Commissioner for Peace or Ministry of Defense developing a list of those demobilized that would be subject to judicial proceedings. ${ }^{41}$ With this list of perpetrators of serious crimes, the Fiscalia's Justice and Peace Unit, now the Specialized Unit for Transitional Justice, requires those on the list to fully account for all of their crimes in order to be eligible for an alternative prison sentence ranging from five to eight years, the length of which is decided by magistrates in special tribunals located in three Colombian cities. For those demobilized that did not commit serious crimes, Decree 128 and later Law 1424 provided amnesty as long as the recipients contributed to truth-telling initiatives.

In support of this accountability mechanism, Law 975 also created The Fund for the Reparation of Victims, which is to provide monetary reparations to the paramilitaries' victims through assets turned-over by the demobilized, with additional support provided by the state as needed. Reparations are to be decided by the magistrates in the Special Tribunals for Justice and Peace based on a valuation of harm. Rounding out this

\footnotetext{
${ }^{41}$ According to Law 975, crimes of the state and its agents are not subject to any of the elements of this law. While this law is primarily focused on the AUC, individual guerillas that demobilized were also able to petition to be included under the benefits of this law.
} 
transitional justice framework was the National Commission for Reparation and Reconciliation (NCRR), whose broad mission was to ensure victim participation in judicial proceedings, submit a report on the reasons for illegal armed groups, monitor reparations and support national reconciliation. (Law 975, Articles 50-51) From these responsibilities, the NCRR assembled the Historical Memory Group (HMG), which although not a truth commission, did produce 24 reports between 2009 to 2013 explaining the reasons for the emergence and evolution of illegal groups by focusing on emblematic cases of violence. ${ }^{42}$ (Alcala and Uribe 2016, 14)

While Law 975 is the bedrock of this initial wave of transitional justice, other elements were added to it over time. The first significant addition came in June of 2011, although the initial impetus for it started four years earlier. Because many victims were not satisfied with the scope of reparations under Law 975, i.e., they also wanted their land returned and psychosocial support, victims began demanding a victims' law only two years after the passage of the Justice and Peace Law. Subsequently, after a multi-year process of public and congressional debate, the Law on Victims and Land Restitution, aka Law 1448, was passed in 2011.

Law 1448 is significantly more comprehensive than Law 975. For instance, the former applies to all victims of the Colombian conflict, defining a victim as someone that has experienced a violation of his/her human rights or rights under international humanitarian law since 1985 . This designation of victim includes not only those targeted

\footnotetext{
${ }^{42}$ A truth commission was not established under Law 975 because the general conflict was still ongoing. (Jaramillo, Giha \& Torres 2009, 36)
} 
by the paramilitaries and guerillas but also those of the state. ${ }^{43}$ Moreover, the law provides for the restitution of land, financial reparations, social services and pledges of non-repetition. Institutionally, the Victims' Law expanded the transitional justice edifice by establishing three key entities, the Victim Assistance and Comprehensive Reparations Unit, the Center for Historical Memory and the Unit to Manage Restitution of Dispossessed Lands.

In addition to being new, the mandate of these three entities is different from those institutions established under Law 975. For example, the Victims' Unit dispenses reparations administratively, i.e., the financial amounts are bureaucratically pre-defined and not determined by the courts based on a valuation of individual harm. This key change will be discussed later since it limited the impact of Law 975, but for now, it is important to note that administrative reparations are generally much less than what is judicially decided. With regards to the element of truth included in Law 1448, i.e., the Center for Historical Memory (CHM), this organization's central aims are to support the construction of a Museum of Memory and aid in the organization of documents and files related to human rights violations. The $\mathrm{CHM}$ is not a truth commission. The advent of a truth commission in Colombia has only recently been agreed to as part of the GoC/FARC peace agreement. The final important piece to this puzzle is the much-needed unit for the return of land, much of this illegally appropriated by the paramilitaries and guerillas to help fuel their illegal activities. ${ }^{44}$

${ }^{43}$ Law 1448 does not, however, extend to victims of BACRIM violence as the GoC does not consider the BACRIM part of the general political conflict. This exclusion has been controversial.

${ }^{44}$ One scholarly assessment notes that more than 13 million acres have been illegally possessed. (Summers 2012, 222) 
According to officials in the Executive Branch, it became apparent under current President Juan Manuel Santos (2010-Present) that Colombia's disparate transitional justice initiatives needed to be organized, streamlined and encapsulated into one comprehensive policy. ${ }^{45}$ While elements of Justice and Peace were up and running, they were not operating efficiently, as exemplified by the slow pace of criminal proceedings under Justice and Peace. For example, the first sentence against a paramilitary under Law 975 came only in June 2010, five years after the passage of the law. To aid in this attempt to improve transitional justice in Colombia, the Santos Administration developed and Congress passed the Legal Framework for Peace (LFP) in June of 2012. This framework authorizes the use of non-judicial mechanisms of transitional justice, and it calls for the prioritization of cases involving international crimes, including those committed by agents of the state. ${ }^{46}$

The general contents of the LFP were fleshed-out through transitory article 66 of Colombia's Constitution, which enshrines the right of truth, justice and reparations, along with the establishment of a truth commission. Moreover, it allows for the prioritization of serious criminal cases. The final piece of the transitional justice structure relevant to this study is Law 1592 (2012). Under the Justice and Peace Law, the Fiscalia is to prosecute all of the individuals that are on the list of serious criminal offenders, regardless of the perpetrator's rank or crime. Consequently, Law 975 was not in sync with the newly-

\footnotetext{
${ }^{45}$ Ministry of Justice \& other government official, interviews, March 8, 2016, Bogota, Colombia.

${ }^{46}$ According to Colombia's Ministry of Justice, prioritization within this context is understood as the focus on prosecuting those senior paramilitary leaders most responsible for serious crimes, taking into account the macro-criminal environment at the time. (MOJ 2015, 13-17)
} 
established Legal Framework for Peace, and its mandate to prioritize cases based on rank, severity of the crime and how that offense fits into the overall macro-criminal enterprises of these illegally-armed groups. In December of 2012, Congress remedied this inconsistency through passage of Law 1592, which established the legal foundation for the prioritization of paramilitary cases.

To review, Colombia's first serious attempt at establishing truth, justice and reparations are encapsulated within the Justice and Peace Law. Law 975 is seminal because it merged DDR with transitional justice, thereby bringing the victims into an otherwise security-centric process. (Laplante and Theidon 2006-07, 76) Moreover, this law departed from the prior decade's reliance upon general amnesties and pardons, and instead opted to try and prosecute thousands of demobilized paramilitaries and guerillas for committing egregious crimes. It also offered aspects of truth-telling through the Historical Memory Group and promised to provide thousands of victims judicial reparations. Over time, weaknesses were realized, and attempts were made to try and alleviate some of these deficiencies through prioritizing criminal cases and expanding the scope of reparations. After the passage of Law 1448, the Legal Framework for Peace and Law 1592, Colombia now has a comprehensive transitional justice strategy, and it had or is utilizing four of the five transitional justice processes identified in Chapter One, including domestic trials, truth-telling initiatives, amnesties and reparations.

While it is clear that this early wave did not include international proceedings, such as sending defendants to an international criminal court, transitional justice by the turn of the twentieth century had reached a steady-state globally and had become part of the package of Western-backed democratic liberal reforms for post-conflict states. (Nagy 
2008, 275-76 and Teitel 2003, 89) Consequently, outside influence and pressure could have been responsible for the content of this early wave. Since it is theorized that the manner of design and implementation are important determinants for transitional justice's success, it is necessary to briefly highlight important markers that demonstrate that this first wave was designed, chosen and implemented by the Colombian government and people. Theoretically, this should have set Colombia on the path to transitional justice success.

\section{The Design of Truth, Justice \& Reparations}

An important lesson provided by the Justice and Peace Law is that in these situations, process matters. That is, while new rules are surely necessary, it is in fact the process through which they are vetted, debated, adopted, interpreted, and implemented that defines the degree to which they can be truly effective. [italics in original] (Carrillo 2009, 155)

At the start of negotiations in 2003, President Uribe enunciated his government's position, namely there will be no impunity, but instead of trying the demobilized, the AUC was to be subject to an alternative justice formula that would have placed the onus on the AUC to provide reparations to its victims. (LatinNews, August 12, 2003) Reflecting this stance, the government sent the Alternative Criminal Sanctions Law (85/03) to Congress in 2003, which outlined a process of demobilization that included modest punishments for the paramilitaries, such as not being able to possess weapons or hold office for ten years, along with requirements for providing reparations. (Carrillo 2009, 135-37)

The Uribe Administration appears to have initially chosen a retributive-light model of transitional justice for several reasons. Some argue that the government's initial bill reflected prior DDR agreements because these processes were relatively successful. 
(Ibid, 138-39) Other possible explanations include that this was what the paramilitaries wanted, and/or the President himself was somewhat sympathetic to their anti-guerilla campaign. (Laplante and Theidon 2006-07, 62) While elements of all of these explanations have merit, the clearest public articulation of why retribution was not initially introduced centered around the need for demobilization. After some segments of society demanded criminal penalties, the government's chief negotiator and Peace Commissioner Luis Restrepo came out against trying the paramilitaries because it might disrupt the delicate demobilization process. (LatinNews, February 22, 2005)

Despite this concern, 85/03 drew widespread criticism throughout Colombia and the international community for its failure to fully address victim suffering and for its weak approach to punishing the AUC. In 2004, the Uribe Administration offered to add a truth tribunal, but following congressional dissatisfaction with these anemic revisions, a rival bill was put forward in early-2005 by a group of congressional parties that introduced prison sentences of one to 10 years for non-pardonable crimes. (LatinNews, February 1, 2005) The same month this alternative bill was put forward, the government again revised its legislative proposal, introducing its own alternative criminal penalties ranging from five to eight years. Colombia's Interior Minister noted that the government had been persuaded to adopt criminal sanctions because of congressional and international pressure. (LatinNews, February 22, 2005)

This new draft was openly debated in Congress with civil society participation, and by June of 2005 the Justice and Peace Law was passed by Congress. Describing this process, Carrillo notes, 
To its credit, the Uribe administration did not press its initial legislative proposal, opting instead to engage in the extended public debates that followed. Political allies and opponents, international and domestic civil society organizations, foreign governments and intergovernmental bodies-all had their say, and all, in their various ways contributed to shaping the final Justice and Peace Law and its implementing norms. $(2009,152)$

Although there was more transparency and public input into Law 975 not everyone was satisfied with the result. Following its promulgation, 105 human rights and victims' organizations jointly filed a lawsuit against parts of the law, primarily in objection to the sections that allowed reduced criminal sentences and excluded victims from judicial proceedings. Following this challenge, Colombia's Constitutional Court upheld the law in general but required modifications to allow greater victim participation in judicial proceedings and enlarged the reparations program. (Laplante \& Theidon 2006$07,81-89$ and 104-05)

While these events speak directly to governmental and societal interests, it is useful to also take note of the position of the other party to these negotiations, the AUC. Like the Uribe Administration, the paramilitaries' positions modified during this multiyear process, but despite being numerically strong, the AUC was weakened politically at the start of these negotiations by international criminal indictments, a new global war on terror and declining Colombian support. Although no AUC leaders or negotiators were interviewed as part of this study, particularly since many are either dead, in jail or were extradited to the United States, it is fair to state that the AUC's interests, particularly that of its leadership, was to cut the best possible deal it could with a government it perceived to be somewhat sympathetic to their cause. ${ }^{47}$ While staying out of prison was a priority

\footnotetext{
${ }^{47}$ Interview, supra n 39.
} 
for this entity, their negotiators were more preoccupied with getting the government's agreement not to extradite its leadership to the United States on drug trafficking charges. This focus on extradition, along with a new post-9/11 environment and domestic disgust with the paramilitaries' behavior, limited the AUC's room to maneuver during these negotiations, thereby making it easier for the government and society to change the initial transitional framework without jeopardizing the overall demobilization process.

For instance, in September 2002, the United States issued its first extradition requests for AUC leaders, including its head Carlos Castaño, and by 2004, four of the AUC's seven negotiators to the peace talks were wanted in the United States. Furthermore, in 2002, Interpol issued red notices (arrest warrants) for three AUC leaders for terrorist acts, and by the time the AUC agreed to negotiate with the $\mathrm{GoC}$, the United States and European Union had already both designated the AUC a terrorist organization, a label that after September 11, 2001, further tarnished its reputation, limited its operating space and helped shape its negotiating positions.

Domestically, any remaining societal support for the paramilitaries' anti-guerilla activities was declining, and tougher sanctions against the paramilitaries were demanded by Colombian society. According to one Colombian scholar and policymaker, the paramilitaries involvement in criminal activity and responsibility for dozens of civilian massacres shifted public attitudes away from forgiveness and political reintegration. (Guaqueta 2007, 437) This unfavorable view of the paramilitaries is reflected in a 2006 International Center for Transitional Justice (ICTJ) survey that found 63\% of Colombians favored prosecutions of the AUC. Moreover, 90\% of survey participants favored reparations for the victims, and 79\% called for a recording of the truth. (ICTJ 2006) 
Interestingly, the public's desire for accountability grew over time. In a separate 2008 poll, 88\% of Colombians supported paramilitary trials. (Lyons and Reed-Hurtado 2010, 6)

In response to the introduction of the idea of criminal trials during the negotiations, the AUC initially threatened to halt demobilizations. As alternative criminal sanctions began to gain traction, the weakness of the AUC at the negotiating table was apparent. In a public communique of March 15, 2005, the AUC noted it would now accept some prison time as long as the possibility of parole was included. The communique goes on to reject the need to confess all of their crimes in order to receive reduced sentences, provide full reparations and issue public apologies. (LatinNews, March 22, 2005) As has already been shown, the AUC's opposition to all of these policies was rejected, although initially extraditions were stayed. ${ }^{48}$

Reflecting on the development of Law 975, it is clear that procedurally, the drafting and ratification of these laws were more democratic than prior peace agreements. During the 1990s, the amnesties given were agreed to behind closed doors between the President and rebel groups. Civil society, congressional and judicial input was minimal at best. A decade later, however, the manner in which the mechanisms were designed and selected was more open to input from various sectors of society and other branches of government through such activities as public and congressional hearings, congressional approval and finally judicial review. Yet, while the process was clearly domestically-

\footnotetext{
${ }^{48}$ In May 2008, President Uribe extradited 14 AUC leaders to the United States because they failed to comply with the terms of the Justice and Peace Law. The extradition of paramilitary leaders has been controversial as some critics believe this was an attempt by the government to silence the paramilitaries about their ties with the government.
} 
managed, are there indicators that demonstrate that the desire for the selection of these mechanisms was domestically-based?

Yes, opinion polling and congressional and civil society activity at that time reflects a much stronger demand for accountability, truth and reparations. This enhanced societal demand was subsequently channeled through a strengthened civil society, as reflected by the number of organizations that joined the lawsuit against Law 975, and these demands were supported by a more evolved criminal code. For example, after the 1998 Rome Conference on the ICC, war crimes became a part of the country's criminal code, and in 2002, the list of pardonable offenses under Colombian law was reduced. Therefore, while civil society was more organized to confront impunity in 2005, it was also able to argue, along with congressional supporters, for changes based upon Colombia's criminal code and international commitments.

This demand for truth, justice and reparations produced results. Recall that a rival bill was introduced in Congress calling for alternative criminal sanctions, which with the support of victims' organizations and the international community, led to changes in the government's position. Moreover, victims' demands for changes to the Justice and Peace Law were reflected in the pursuant Constitutional Court's decision. ${ }^{49}$ Similarly, a strong domestic impetus helped secure passage of the Victims' Law. Beginning in 2007, at least nine public hearings were held by the government soliciting victims' input, and by 2011 , Colombia had a comprehensive reparations law that reflected the victims' demands for the return of their land and psychosocial support. ${ }^{50}$

\footnotetext{
${ }^{49}$ Please see the Constitutional Court's decision of May 18, 2006, in Gustavo Gallón Giraldo y Otros v. Colombia, C-370/06.
} 
Unfortunately, when it comes to the Legal Framework for Peace and Law 1592, victim demands have not always been fully reflected in these decisions, but the impulse for these changes did come from inside of Colombia. According to officials in the Executive Branch, the Santos Administration began a review in 2010 of Law 975 and transitional justice in general. The major finding from this process was that transitional justice in Colombia relied too heavily upon the courts; more specifically, they concluded that the courts should not be the central mechanism to deliver truth, justice and reparations. Furthermore, the government recognized that the prioritization of cases involving serious crimes needs to be the prosecutorial strategy moving forward. The Santos Administration discovered that within a post-conflict environment, case prioritization is essential because there are too many perpetrators and too few resources to prosecute them all. ${ }^{51}$

Subsequently, the Legal Framework for Peace was assembled to unite the previous disparate elements of transitional justice within one comprehensive policy that promotes prioritization, while recognizing the need for other mechanisms, such as a truth commission. Law 1592 was also a natural outgrowth of this overall strategy since Justice and Peace was not in accordance with the over-arching LFP. Although the GoC pushed these reforms, namely prioritization, it should be noted that not all elements of Colombian society agree with this shift in policy. One government lawyer charged with representing the interests of the victims referred to Law 1592 as the "beginning of

\footnotetext{
${ }^{50}$ Subdirector of the Victims Unit, phone interview, April 13, 2016, Bucaramanga, Colombia.

${ }^{51}$ Interview, supra $\mathrm{n} 45$.
} 
impunity," and this official noted that many victims left the Justice and Peace process after prioritization due to their disappointment with the change. ${ }^{52}$

How this shift affected the implementation of Law 975 will be discussed later, but while internal disagreements persist, Colombian society and government were the primary forces behind shaping the substance of this overall wave of transitional justice. After more than three decades of paramilitary activity and the hundreds of thousands of victims that had been killed, tortured, raped or displaced, Colombians generally recognized something more was needed than the usual disarmament, demobilization and reintegration agreement. Yet, while domestic forces were primarily responsible for setting the overall framework of Law 975 and its pursuant policies, international actors played an important, yet supporting role.

During the drafting of Law 975, pressure from the international community provided critical support for domestic non-governmental organizations demanding a more robust law. For instance, in 2005, Secretary of State Condoleezza Rice told the U.S. Congress that as part of the ongoing peace process, Colombia should not offer immunity to those "with blood on their hands." (LatinNews, January 25, 2005) The U.S. Under Secretary of State Marc Grossman visited Colombia in 2005, and his public remarks during his trip reiterated the need for a robust reparations program and punishment of criminals. (LatinNews, February 22, 2005) The views of U.S. officials were, and remain, important. Following the multi-billion dollar launch of Plan Colombia in 1999/2000, President Uribe relied upon U.S. security assistance to combat the guerillas and further

\footnotetext{
${ }^{52}$ Procuraduria, interview, February 26, 2016, Bogota, Colombia.
} 
his Democratic Security Policy. Upsetting Colombia's largest bilateral donor was likely something the GoC could not afford to do. But, the U.S. was not the only outside party encouraging Colombia to do more.

In addition to the importance of U.S. views, the ICC should also be recognized as another international entity that helped shape this first wave. In 1998, Colombia became a party to the Rome Statute, and the ICC opened a preliminary examination of the situation in Colombia in June of 2004. Reflecting on the importance of having the ICC monitoring Colombia, the Colombian Ministry of Justice concluded,

Besides the assessments of whether Justice and Peace satisfies the principle of complementarity -which continues to be the object of OTP examination- the truth is that this constant international supervision places strict responsibility upon the Colombian authorities and it obligates them to deliver results that comply with the state's international obligations in terms of prosecution and access to justice. $(2015,49)$

The influence of this international court is also reflected in the Legal Framework for Peace and Law 1592. More specifically, the ICC and the ad-hoc international criminal tribunals that came before it, operated on the principle of prosecuting only the most senior government and military officials responsible for the most serious crimes. After evaluating Colombia's LFP and overall shift to prioritization, the ICC's Office of the Prosecutor signaled its support for this change so long as it does not shield perpetrators of serious crimes from prosecution. (ICC 2012, 63)

Returning to this section's original question, there is strong evidence to support the notion that the impulse to adopt a policy of truth, justice and reparations emanated from Colombian society and government. Clearly, as reflected in public opinion polling, Colombians demanded more than just demobilization with amnesty. A desire for those 
perpetrators of civilian massacres, displacements and rape to stand trial was a strong current within society. Moreover, the victims' demands for comprehensive truth, justice and reparations is reflected in their ceaseless pursuit to first improve Law 975 and then seek the Victims' Law. Moreover, the GoC's decision to change some policies, namely to allow prosecutorial prioritization, was based upon a clear domestic reality of being unable to adjudicate the full list of paramilitary defendants due to limitations in resources.

Obviously, these processes did not occur in a vacuum. International pressure was applied, and international norms were taken into account. Yet, these ideas and mechanisms were not foisted upon Colombian society or government; domestic actors retained the political space to adapt certain policies to Colombian realities. Furthermore, since the 1990s, a more vibrant civil society has emerged, and this energized element was able to capitalize on changes in domestic law, as well as Colombia's international commitments, to advance their interests.

In addition to being domestically designed, the implementation of Law 975 has been domestically-based, although there has been some financial support from donors, particularly the United States. The special tribunals established under the law are fully staffed by Colombian magistrates, and the Fiscalia's specialized unit is comprised of Colombian investigators and prosecutors. Moreover, the Historical Memory Group was comprised of Colombians, and reparations are funded by the demobilized and state. In light of these facts, Colombia's first serious wave of transitional justice represents a fully domestic model, utilizing domestic trials, truth-telling, reparations and amnesties. The ability of Colombia to choose and implement its own mechanisms of transitional justice should have set the stage for Colombia's success in using this process to help improve its 
rule of law. Yet, due to implementing challenges and the persistence of rule of law inhibiters, any positive effects from domestic design and implementation were minimized.

Implementation of Law 975 \& Its Effects

Chapter One introduced Kleinfeld's work on the five common end goals of rule of law reform. Instead of focusing solely on passing the right types of laws and establishing institutions, Kleinfeld encourages rule of law reformers to focus on achieving important ends as a measure of success. Simply having the right legal code or adequate number of lawyers and judges is not enough in order to evaluate whether a society is truly governed by the law. (Kleinfeld 2006) Consequently, in this and the following chapter, each of these five end goals will be broken down in order to assess where transitional justice did or did not impact the rule of law, thereby helping develop a theory of change for mechanisms such as trials and reparations. The five ends include having a government subordinate to the law; ensuring the equality of all before the law; maintaining law and order; having a predictable and efficient judicial system; and upholding human rights. Within this study, ends number one and two will be considered together since they are closely related.

\section{Government Subordinate to the Law \& Equality of All Before the Law}

Colombia's first wave of transitional justice struggled to subject the government to the law. The structure of Justice and Peace, and the pervasiveness of paramilitary influence within all levels of the government impeded these mechanisms from making any major inroads in establishing the equality of all before the law. Moreover, the emergence of the military's involvement in "false positives," i.e., civilians were killed by 
the military and later presented as guerillas, only further eroded any notion that government impunity is being seriously addressed.

According to Law 975, only the crimes of illegal armed groups are subject to the terms of this law. (Articles $1 \& 2$ ) Any state collusion with the paramilitaries or illegal conduct by agents of the state are not subject to the criminal, truth-telling or reparative proceedings of Justice and Peace. Moreover, the Executive Branch determined which paramilitaries or guerillas warranted inclusion on the list of serious offenders. Therefore, those cases put on the list for the Fiscalia and Special Tribunals to adjudicate were based on political decisions and not as the result of criminal investigations. When an official in the Fiscalia was asked about this process, the interviewee noted that there were some demobilized not included on the list that the Fiscalia believed warranted inclusion. ${ }^{53}$

While the optics of politicians and bureaucrats selecting who would be subject to criminal proceedings is questionable at best, it is the government's collusion with the paramilitaries over several decades that raises red flags about these decisions. In a special report entitled, "Colombia Elites and Organized Crime," a non-partisan investigative organization, InSight Crime, reported that three years after Law 975 was passed, onethird of Colombia's Senate was under investigation for ties to the paramilitaries. Furthermore, by 2014, 61 members of Congress had been convicted of illegal ties to the AUC, and another 60 were under investigation. Overall, throughout the country, more than 11,000 individuals have been investigated in what has become known as the "para-

\footnotetext{
${ }^{53}$ Fiscalia, interview, February 26, 2016, Bogota, Colombia.
} 
political scandal," which included 900 politicians, 800 members of the military and 300 other government officials. $(2016,19)$

Additionally, there remain serious questions about the extent of the reach of the paramilitaries, including whether it permeated the Presidency of Alvaro Uribe. Following the testimony of several demobilized paramilitaries, a judge ordered a congressional investigation of former President Uribe's ties to the paramilitaries. According to testimony given within the Special Tribunals, multiple paramilitaries claimed Uribe collaborated with them while he was governor of Antioquia during the 1990s. (Parkinson, 2013) Whether these allegations are true have not yet been proven, but the arrest and indictment of the President's brother and cousin for para-politics only heightens questions about the political influence of the paramilitaries.

Although Colombia should be applauded for the work it has done to weed-out this stain on its political system, the effects of para-politics continues to be felt. For instance, in 2015, Colombia's prison service was forced to address disparities in the treatment of para-political prisoners. Within Bogota's La Picota prison, those convicted of ties to the paramilitaries have been able to remodel their cells, which included installing showers and televisions, they placed their own locks on their cell doors, were found with refrigerators stocked with liquor, had a separate section for a hairdresser and massage parlor and one former politician recently celebrated his birthday in prison by welcoming 34 guests into the jail over a two-day period. (Bargent 2015) Equally disturbing were the results from the 2014 national congressional elections. Following this plebiscite, 69 candidates were elected that are believed to have had ties with the paramilitaries or are linked to politicians that did. (Cawley 2014) 
Furthermore, in 2012, the ICC's Office of the Prosecutor noted that it is reasonable to assume that the state is responsible for crimes against humanity and war crimes since its jurisdiction began in Colombia in 2002. (ICC 2012,4) Despite these accusations, the state has not been subjected to any type of transitional court or truthtelling process, although the Legal Framework for Peace does finally accept some state culpability. While this change is welcomed, to date, agents of the state have still not had to subject themselves to these types of mechanisms, although under the terms of the GoC/FARC peace agreement they will have to do so.

Yet, while the Santos government recognized the need to subject the state to mechanisms of transitional justice, this positive step has been tainted by the emergence of the military's involvement in false-positives. According to a November 2013 letter from the Fiscalia to the online news source Colombia Reports, this country's Attorney General's Office identified more than 3,800 victims as a result of this behavior. The Fiscalia noted that these actions began in earnest (more than 100 victims a year) in 2002, and they reached their zenith in 2007 when 1,119 civilians were killed at the hands of the military.

Fortunately, the Fiscalia's records indicate that these actions began to abate in 2008, and four years later there had only been 15 reported false-positive deaths. Unfortunately, while the number of victims subsided, impunity has also been a pattern as it relates to these crimes. As of September 2013, only two senior army officers had been convicted for their involvement in false-positives, one of which was also convicted for collaborating with the paramilitaries between 2002-2004. (Parkinson 2013) The effects of the failure to deal swiftly and comprehensively with these crimes is reflected in a 2012 
poll for Colombia's National Center for Historical Memory. When asked why justice has not followed the human rights crimes committed during the conflict $39 \%$ of the conflict's victims identified impunity as the culprit; the second highest category chosen, at $27 \%$, was the continuing violence. (Center for Historical Memory 2012, 38)

In addition to impunity, the state's absence in the Justice and Peace processes has been felt in other ways. Two members of the Historical Memory Group recalled that some victims were skeptical of this truth-telling initiative because the state's activities were not part of this group's mandate. (Alcala and Uribe 2016, 19) Another individual involved in official memory projects in Colombia, noted that when the culminating report of the NCRR was released, which is entitled "BASTA YA!," the military criticized it as ideologically biased since the armed forces claim the report portrays them as the victimizers. Looking ahead to the upcoming truth commission, this individual opined that the military remains concerned about their portrayal in any future reports, and identifying a balanced truth will be difficult. ${ }^{54}$

Clearly, there is evidence that indicates that this first wave of transitional justice struggled to counteract decades of government impunity. In fact, scandals such as parapolitics and false-positives were more likely to negatively affect the rule of law. For example, the Institute for Management and Development's World Competitiveness Yearbook, which is part of the WGI, includes a yearly measure on whether justice is fairly administered in a country. According to these findings, the fairness in the applicability of justice in Colombia has deteriorated. Before 2005, Colombia averaged a

\footnotetext{
${ }^{54}$ Individual involved in memory projects, interview, March 7, 2016, Bogota, Colombia.
} 
2.5 out of 10, with 10 being the best. While this score improved slight to a 3-4 from 2005-2011, it has since declined dramatically, reaching a 1.9 in 2015. (WGI)

Slightly more positive, the Bertelsmann Transformation Index, which includes a measure of the prosecution of those who abuse their positions of power, shows slight improvement from 2006 to 2016. From 2006 to 2012, Colombia received a rating of five, which indicates abusers of government office are not adequately prosecuted. Only in 2014 did this score rise to a six out of ten. (BTI) One possible explanation for the BTI's change in score could be explained by the judicial response to para-politics, but it is unclear why these two indicators are moving in different directions, although differing expert opinions could explain these contradictions.

While these sources do not discuss why there are changes, it is reasonable to assume that the absence of the state from the proceedings of Law 975, coupled with the toll of para-politics and false-positives, interfered with any possible positive effects emanating from the limited paramilitary trials. It is also reasonable that the fallout from these scandals, which involved violations of international law, continues to erode confidence in the fairness of Colombia's judicial system. Even if politicians are convicted of supporting the paramilitaries, the treatment they receive in prison is a clear indication that a double-standard exists.

\section{Law \& Order}

While transitional justice had little effect subordinating the government to the law, Law 975 and its accompanying demobilization procedures helped improve law and order in Colombia. This initial wave of DDR, tied closely to amnesties for the majority of demobilized, removed more than 50,000 paramilitaries and guerillas from the conflict. 
The absence of these actors has led to a noticeable decline in overall political violence, kidnappings and civilian deaths. Yet, while there are improvements, non-conflict related crimes have gone up, and the general lack of an enduring governing presence in former conflict regions continues to allow criminality and violence to persist.

Since the tumultuous 1990s-early 2000s, the number of civilian deaths caused by the conflict has declined, along with the number of kidnappings. At the turn of the century, kidnappings were commonplace; in 2003 alone, 2,200 individuals were abducted. Yet, following implementation of this first wave of transitional justice and demobilizations, kidnappings declined precipitously and continue to subside. For instance, only 111 individuals were kidnapped during the first seven months of 2015. (U.S. Department of State Human Rights Report)

Moreover, according to the Historical Memory Group's final report, the number of civilians killed as a result of the conflict has also decreased in keeping with the emergence of DDR and transitional justice. In 2001, approximately 14,000 noncombatants were killed, yet by 2005, the number had fallen to around 6,500. By 2011, it was estimated that only 1,500 civilians were killed. (Historical Memory Group) Figure 3.2 below outlines the overall trends in both kidnappings and civilian deaths since 2004 . 
Figure 3.2: Number of Yearly Kidnappings and Civilian Conflict Deaths

\section{Conflict-Related Crimes}

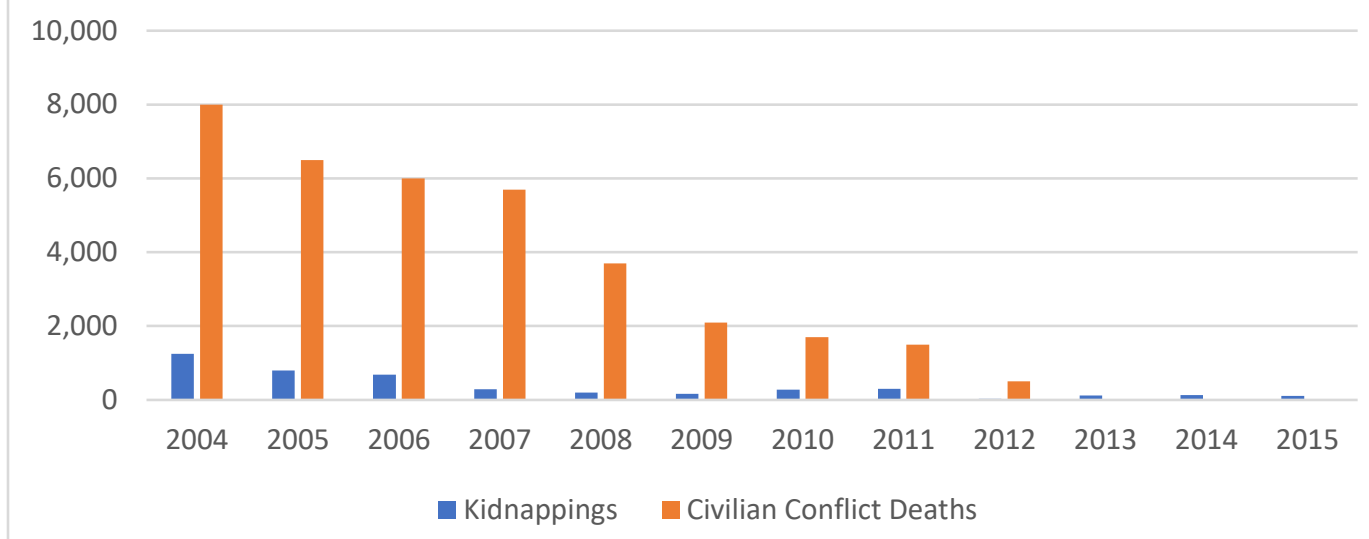

*The numbers of kidnappings come from the U.S. Department of State Human Rights Reports and the numbers of civilian deaths is taken from BASTA YA!.

**Civilian deaths for 2013-15 were not reported in BASTA YA!.

***The 2007 kidnapping figure covers January-August; the 2013-14 kidnapping figures cover JanuaryJune; the kidnapping figure for 2015 covers January-July.

Digging deeper into overall criminal trends, the impact of transitional justice appears to be weaker or a non-factor in disrupting things like theft or other non-conflict related offenses. As part of their ongoing survey of publics throughout Latin America, Latinobarometro, which is also part of the WGI Rule of Law score, found that in Colombia crime victimization has been on the rise. Colombian respondents have been asked whether they or a family member have been a victim of a crime in the last 12 months. In 2004, 24\% answered yes, 37\% said the same a year later, and by 2010, 32\% reported a crime in their family. By 2015, however, $43 \%$ of respondents reported either personal or family victimization. (Latinobarometro)

Unfortunately, these polling figures are supported by actual crime statistics. According to the UN Office on Drugs and Crime (UNODC), thefts have increased dramatically since 2005. For instance, the year the Justice and Peace Law came into effect, there were 159 thefts per 100,000 people in Colombia. By 2010, this figure had 
grown to 200, and most recently it was a little more than 286 thefts per 100,000. In relation to assaults, this crime is also on the rise. While there were only 70 assaults per 100,000 individuals in 2005 , this rate has more than doubled, reaching 172 per 100,000 in 2014. Consequently, the effect of transitional justice to help deter and/or reduce nonconflict related crimes does not appear to occur, as least not in Colombia. It could be that the types of crimes addressed by transitional trials and truth-telling, such as war crimes and crimes against humanity, do little to deter everyday criminals more concerned with economic gain.

While the indicators show a positive trend in reducing conflict-related violations, some of which can be attributed to the transitional policies implemented since 2005 , i.e., amnesty for most of the demobilized, the lack of the state's presence in conflict-affected regions has hindered further progress in solidifying law and order. One year after passage of Law 975, the MAPP in its sixth quarterly report of February 2006, drew attention to the development of new criminal actors comprised in part of demobilized AUC members. This international mission reported that these groups were emerging in areas where a security vacuum was created following the demobilization of the AUC. (10) According to this organization's reports, these bandas criminales (BACRIM) are criminal elements primarily involved in drug trafficking and extortion. While they consist of demobilized AUC members, the BACRIM are not the reemergence of paramilitarism in Colombia. (MAPP $12^{\text {th }}$ report) To support these claims, the MAPP reported in its $16^{\text {th }}$ report that of the 11,524 BACRIM arrested by Colombian security services, only 1,680 were demobilized AUC. (10) 
Nevertheless, the failure of the state to fill the security vacuum in remote areas has allowed criminality to persist. According to Senator Navarro Wolff, he, along with other congressional members, proposed to the Santos Administration a plan to enhance the presence of the state in 172 municipalities over the next 10 years. He reported that government representatives were generally open to the idea, but they noted that the state could not afford the 57.3-billion-peso price tag (\$20 million). Emblematic of the absence of the state, one government official who works with the victims of the conflict, recounted a recent trip he had taken to a village in the northern Andes Mountains after 2005. He reported that when he entered the village, he was informed that he was the first government official to visit. Both he and Senator Wolff believe that in addition to inadequate resources, some elites lack a general concern for the well-being of those regions outside of the major cities.$^{55}$ If these hindrances to move beyond the cities persist, criminality will continue to thrive in areas affected by the conflict.

\section{Predictable \& Efficient Justice}

Overall, the administration of justice and reparations, which is also administered through the courts under Law 975, has been anything but predictable and efficient. Judicial proceedings have been tragically slow, and policies designed to improve reparations are confusing. Moreover, initial promises made by the government have not been met, thereby dashing victims' expectations for truth, justice and reparations. The cause of these inefficiencies does not appear willful; like most conflict and post-conflict states, resources and institutional capacity are scarce commodities in Colombia.

${ }^{55}$ Interviews, supra n $39 \& 52$. 
Colombia's judicial system has been particularly prone to these institutional deficiencies, but fortunately, this reality is beginning to improve, largely due to case prioritization and administrative reparations, both of which carry their own challenges.

Based upon an examination of several WGI rule of law indicators relating to this end-goal, Colombia's judiciary receives mixed marks. According to the BTI measurement on the independence of the judiciary, the situation is improving. Between 2006 to 2008, Colombia's judiciary was relatively impaired by political interference and corruption, scoring a five out of 10. By 2016, Colombia improved to a seven, signifying a largely independent judiciary. This rating, which is based on expert analysis, is questionable. Clearly, Colombia's judicial system has struggled to respond to parapolitics and false-positives, although it has not been entirely silent. Moreover, as will be discussed later, corruption permeates all levels and branches of government. Whether Colombia deserves a seven from the BTI on this metric can be debated, and any BTI claims of progress here should not be overstated. Another indicator of progress, which is closely tied to Law 1448 and is less controversial, is the rating of the protection of property rights.

The Heritage Foundation Index of Economic Freedoms noted that property rights were low in 2004 with a rating of 30 out of 100, but after implementation of the Victims' Law in 2011, Colombia has maintained a property rating of 50. (WGI) Although far from perfect, Colombia's improvement can be traced directly to this law's attempt to return dispossessed land. Colombia's efforts to restore illegally appropriated property to their rightful owners through transitional mechanisms has had a positive impact of the development of the rule of law. While still in its early stages, more than 81,050 land 
restitution claims have been submitted, of which 2,450 have been adjudicated. These decisions have returned more than 100,000 hectares of land to more than 15,000 victims. (Correa 2015, 22-23 and MAPP $21^{\text {st }}$ report, 5) While there remain many more claims to process, restitution proceedings are underway, and are moving more rapidly than the judicial and reparation processes under Law 975.

Yet, while some metrics are improving, others are not as reflected in Table 3.1. According to Latinobarometro, public trust in the judiciary is declining since the introduction of transitional justice. For instance, in 2004, 55\% of respondents had little to no trust in the judiciary; by 2015, this level had grown to $75 \%$. Although not quite as dramatic, distrust in the police is growing as well, moving from 51\% in 2004 to $56 \%$ in 2015.

Table 3.1: Colombians' Trust in the Judiciary and Police

\begin{tabular}{|c|c|c|c|}
\hline & $\mathbf{2 0 0 4}$ & $\mathbf{2 0 1 0}$ & $\mathbf{2 0 1 5}$ \\
\hline $\begin{array}{c}\text { Little to No Trust in } \\
\text { the Judiciary }\end{array}$ & $55 \%$ & $59 \%$ & $75 \%$ \\
\hline $\begin{array}{c}\text { A lot to Some Trust } \\
\text { in the Judiciary }\end{array}$ & $41 \%$ & $34 \%$ & $23 \%$ \\
\hline $\begin{array}{c}\text { Little to No Trust in } \\
\text { the Police }\end{array}$ & $51 \%$ & $53 \%$ & $56 \%$ \\
\hline $\begin{array}{c}\text { A lot to Some Trust } \\
\text { in the Police }\end{array}$ & $48 \%$ & $47 \%$ & $44 \%$ \\
\hline
\end{tabular}

*Data is from Latinobarometro.

Results from a similar question in Latinobarometro, which asks respondents to rate the performance of the judiciary, is equally troubling, although perceptions of trust are much lower. For instance, the percentage of respondents that rated the judiciary as either bad or very bad began at $37 \%$ in 2006 , slightly rose to $38 \%$ in 2008 , and then jumped almost 20 points by $2015(56 \%)$. While various factors have contributed to this deterioration, such as persistent corruption, the failure to adequately implement the judicial components of 
Law 975 has had negative repercussions on perceptions of trust and performance of Colombia's judiciary.

For instance, from June of 2005 until March of 2014, the Fiscalia had 5,025 individuals on its list of serious criminal offenders from the demobilization process. Yet, as of May 2015, only 2,053 had been charged or were awaiting charges, and of these individuals, only 47 have been sentenced by the end of $2016 .{ }^{56}$ Moreover, the pace of terminating judicial proceedings did not accelerate until after the prioritization strategy began. From 2005 through 2013, only fourteen demobilized paramilitaries were sentenced, averaging only 1 and a half sentences per year. Fortunately, since 2014, Colombia has averaged 11 sentences per year due in part to the prioritization plan. (Fiscalia a and b) While this is a positive trend, credibility was already lost as a result of delays, which were only compounded by a change in prosecutorial strategy. Assessing the impact of these judicial delays, the MAPP reported that the painstakingly slow pace has "affected the credibility of the process." $\left(16^{\text {th }}\right.$ report, 2$)$

As part of the Justice and Peace process, the Fiscalia recorded 370,954 crimes covering 487,634 victims. (MOJ 2015, 3) The sentences handed-down have covered more than 22,000 of these approximate half-million victims and accounted for more than 4,600 crimes. (Fiscalia a) While this is significant and has certainly brought justice to several thousand individuals, it only represents less than $5 \%$ of the overall total number of victims and only around $2 \%$ of the overall number of crimes reported.${ }^{57}$ Compound

\footnotetext{
${ }^{56}$ According to the Ministry of Justice, 2,147 of the more than 5,000 initially put on the list have either died or renounced their participation in the Justice and Peace process.

${ }^{57}$ It needs to be noted that as part of the Justice and Peace proceedings, 6,712 versiones libres were held, more than 15,000 cases were transferred to the regular courts involving third parties and 6,729 bodies have
} 
this with the implementation of a prioritization strategy, which removed more than 600 demobilized from the list of serious criminals, and the GoC clearly failed to fulfill its promises.

The effects of the slow pace of judicial proceedings and switching prosecutorial strategies mid-stream have been deleterious. Officials in both the Procuraduria and other government agencies that have mandates to represent Justice and Peace victims, reported that after Law 1592 many victims abandoned the Justice and Peace process altogether because they were disillusioned with the process and had lost faith in the justice system. ${ }^{58}$ These sentiments were confirmed by the MAPP in its twenty-first report. Evaluating the effects of the changes caused by prioritization, this mission informed its Secretariat that victims were now more frustrated and surprised by this policy change, and that the government did a poor job of explaining it. (9) The repercussions of initially promising hundreds of thousands of victims an opportunity to confront their perpetrators in a court of law only to reverse that promise is particularly damaging in a transitional setting like Colombia. Many of the more than 400,000 Justice and Peace victims live in remote regions of the country where the state is usually absent. Yet, when they experience the state for the first time through transitional justice, the government fails to deliver on its stated promises.

The problems with administering justice are not only felt by the victims. The delays in adjudicating the criminal cases has also caused problems with the detainees.

\footnotetext{
been discovered, of which 3,330 have been returned. (MOJ/Fiscalia) Note: Versiones libres are the deposition-like sessions conducted by the Fiscalia where the demobilize confess to all of their crimes.

${ }^{58}$ Supra n 52 and other government official, interviews, March 3, 2016, Bogota, Colombia.
} 
Under Law 975, the demobilized could serve no more than eight years in jail; now, in 2017, more than a decade after the process began, dozens of detained prisoners are being released on parole without a judicial decision because their time in prison has exceeded the legal limit. The Colombian Ministry of Justice believes there are least 40 individuals detained under Justice and Peace that are now free, and an additional 30 have petitioned for release. (MOJ 2015, 34, MAPP $20^{\text {th }}$ report, 7) While these prisoners have already admitted to some degree of guilt by agreeing to be part of Justice and Peace, these prisoners have the right to come before the court in a timely manner and to serve no more than the legal maximum sentence. Developing the rule of law requires that not only are the needs of the victims satisfied, but justice for the perpetrators must also be timely and fair.

In addition to failing to deliver timely verdicts, the justice system was also not prepared to deliver reparations. According to Article 37.3 of the Justice and Peace Law, victims are entitled to "prompt and comprehensive" reparations from their perpetrators. Under this law, the Special Tribunals' magistrates are the ones that determine the level of financial reparations based on an individual valuation of harm. But, much like the sentencing of the demobilized, significant delays and policy changes have also disrupted any possible positive effects from these reparation proceedings. Since reparations under the Justice and Peace Law are determined at the end of a judicial process, which can last anywhere from five to seven years, determinations of who receives reparations and how much must wait until this lengthy process concludes with a sentencing verdict. Consequently, the first judicial award was not given until six years after the passage of Law 975. Moreover, out of the more than 400,000 victims, only 3,270 have received any 
type of judicial reparations as part of the sentences handed-down. ${ }^{59}$ When polled seven years after the passage of 975 only $7 \%$ of conflict victims had received any type of monetary remuneration. (Center for Historical Memory 2012, 79) While the failure to recognize the majority of victims is being reconciled through the Victims' Law, which provides administrative reparations, using two simultaneous procedures is not without its problems.

In fact, since 2005, Colombia has experimented with four different reparation schemes. (MOJ 2015, 29-30) Paramilitary victims were initially promised judicial reparations, but with Law 1592, all victims were placed under an administrative allocation. The Constitutional Court ruled this provision of 1592 unconstitutional, and power was returned to the magistrates to determine reparations within the Special Tribunals. Now, victims under Law 975 receive reparations under a mixed formula that may draw from either judicial or administrative accounts. Subsequently, while paramilitary victims may still petition for judicial reparations, other conflict victims must go through the Victims' Unit. Here, a decision regarding eligibility is normally given within 90 days of application, but the amount is much less. ${ }^{60}$ For example, if a family petitions for reparations based upon the murder of a loved-one, under the judicial proceedings, victims of homicides typically receive 823 million pesos $(\$ 280,000)$, while for the same crime, a victim under the administrative track will only receive 24 million $(\$ 8,168)$. (Ibid, 29) While the Santos government decided to provide reparations for the

\footnotetext{
${ }^{59}$ Supra n 50.

${ }^{60}$ The Victims' Unit has provided administrative reparations to more than 590,000 victims. (Interview, supra n 50)
} 
majority of conflict victims through a more efficient and cheaper administrative process due to implementing challenges with the judicial system, it created a double-standard. Whether one suffered victimization under the hands of the paramilitaries, guerillas, or state, reparations for the same crime should be equal for all.

Moreover, while trying to track which victim is covered by which reparation process is hard enough for any researcher, imagine the difficulty victims in remote regions without regular access to public defenders and the internet have in trying to determine their eligibility. The frustration these changes brought has been noticed by the MAPP. In its $11^{\text {th }}$ report to the OAS Secretariat, the mission reported, “...that despite the fact that the reparation stage has not yet begun, great expectations have been generated among victims regarding money and property they may receive from postulados, [demobilized paramilitaries] through the victim Reparations Fund..." [italics in original] (13) By its $21^{\text {st }}$ report of May 2016, the mission identified a more somber reality reporting, "... during the hearing held in March 2015 on monitoring the implementation of the Justice and Peace Law, social organizations stated that very little has been achieved on truth, justice, and redress, and that there is a serious lack of victim participation as well as delays in the proceedings envisioned in the law. They also felt that the state lacks a plan to fix this situation." (9)

Colombia's problems in ensuring that its transitional justice processes are predictable and efficient are due in large part to its institutional weakness and lack of state capacity. In 2007, the Fiscalia reported that in addition to the 23 prosecutors and 150 investigators it had in its Justice and Peace Unit, it still needed 1,235 more if it was to adequately handle the caseload. Three years later, this unit had 159 prosecutors and 
1,000 investigators, but it was still not enough as each prosecutor had 240 incidents to investigate. (MAPP $10^{\text {th }}$ and $14^{\text {th }}$ reports, 8 and 7) By 2016, this unit was down to only 500 prosecutors and investigators throughout Colombia. ${ }^{61}$ Generating sufficient legal support for the victims was equally problematic. Despite almost half a million victims, the Defensoria del Pueblo was only able to muster one defender for every 400 victims. (MAPP $13^{\text {th }}$ report, 4)

Financially, the realities of more than half a century of violence has strained the ability of the government to meet its reparation commitments. According to the Subdirector of the Victims' Unit, the government initially appropriated 55 billion pesos (\$18.7 million) for the implementation of Law 1448; yet midway through its mandate, this unit had already handed-out more than half of this allotment due to the fact that $40 \%$ more victims registered since the law was put into place. This official noted that the government now needs to do a recount to determine how much more money and time is needed to complete the administrative reparation process. ${ }^{62}$ In terms of the Reparations Fund for 975, this too will likely be unable to meet its financial demands. Of the 63 billion pesos (\$21.4 million) within this account, the demobilized have only contributed six percent with the government providing the rest. (MOJ 2015, 31) If required to meet the reparation needs of all the conflict victims, the $\mathrm{GoC}$ is going to be hard pressed to fully fund both accounts, particularly if the magistrates continue to award reparation amounts at higher levels and the demobilized continue to refuse to turnover their assets.

\footnotetext{
${ }^{61}$ Supra n 53.

${ }^{62}$ Supra n 50.
} 
Although some may counter that these results are due to a lack of political will, the evidence does not seem to support this explanation. In 2012, the ICC opined that delays in Justice and Peace were not due to a lack of political will. In fact, this international court was pleased with the more than 200 FARC, ELN and paramilitary trials that had taken place in Colombian courts. Moreover, the ICC's prosecutor explained that the pace of proceedings was due in large part to the complexity of these cases, and in order to help, a prioritization plan should be implemented immediately. (ICC 2012, 5 and 62) When interviewed, a magistrate in one of the Special Tribunals agreed with the ICC's assessment, and encouraged skeptics to compare the pace of Colombia's transitional courts to those used in other countries.

When I compared the pace of the Justice and Peace tribunals to that of the ICTY, Colombia appears to be in good standing, at least since 2014. Since the inception of the ICTY in 1993, it has indicted 161 individuals, and after 22 years it closed 149 cases, which averages 7 cases a year. (ICTY) Since 2014, Colombia averaged 11 sentences per year, although from 2005 to 2013 its turnover rate of 1 and a half cases a year is far below the ICTY's average. In relation to other local war crimes tribunals, Colombia does not fare as well. For instance, BiH's War Crimes Chamber has averaged 23 cases a year since 2013, and in this Balkan state, 361 war crimes cases have been adjudicated since 2004, which included more than 500 defendants. (OSCE 2015, 1) Moreover, Bosnian courts are much more efficient. According to the Organization for Security and 
Cooperation in Europe, the average length of time for a war crimes case is one to two years in $\mathrm{BiH}^{63}(\mathrm{OSCE} 2011,56)$

Consequently, why are Colombia's courts less efficient, when compared to $\mathrm{BiH}$, as it relates to war crimes cases? Here, the utility of a mixed model of transitional justice becomes apparent. Although discussed more fully in the next chapter, $\mathrm{BiH}$ has benefited from almost two decades of international assistance and training, which has included a hybrid war crimes tribunal. While donors have provided some financial and technical assistance to Colombia's Justice and Peace process, an already fragile domestic judicial system strained by more than 50 years of violence has relied upon Colombian investigators, prosecutors and judges. According to the MAPP, throughout all of its 21 reports, this organization consistently explained implementation delays as a result of a lack of institutional capacity. Restrepo agrees, writing, "It seems harsh but fair to conclude that the Justice and Peace Law created more expectations than it could hope to fulfill. Limitations of capacity were forgotten, recent international experiences of transition disregarded.” (2012, 163-64) Subsequently, although pure speculation at this point, one may question whether Colombia would had benefited from a hybrid tribunal, particularly considering that it initially sought to prosecute 5,000 individuals.

As mentioned before, this first wave of transitional justice did not entirely fail to help improve the predictability and efficiency of Colombia's judiciary. In fact, transitional mechanisms contained in Law 1448 related to the return of illegallyappropriated land are having a positive effect on the rule of law. Yet, despite

\footnotetext{
${ }^{63}$ Kosovo's hybrid war crimes court is more in-line with Colombia in terms of performance having only tried 47 cases from 1999-2013. (OSCE 2010, 8, EULEX 2013) An explanation for Kosovo's lack of efficiency is discussed in Chapter Four.
} 
improvement in protecting property rights, delays in implementing components of Law 975 , along with radical changes to the transitional policies, can be clearly traced to indices that show a decline in public trust and satisfaction with the courts.

While adjudicating complex war crimes cases are certainly not easy, resolving only 14 cases in eight years is disappointing within any transitional context. The government had promised through Law 975 that it would put approximately 5,000 individuals before the courts. The fact that only 47 of these individuals have completed the process while hundreds of others were removed from the list due to prioritization is bound to damage the integrity of the justice system. In 2010, two years before prioritization, only 59\% of Colombians had little to no trust in their judiciary. While dismal, after prioritization, this level of dissatisfaction increased to $75 \%$. While these surveys measure general attitudes and not only those of the victims, these findings are supported by the MAPP/OEA's and public officials' accounts of victims' reactions.

Apparently, within a conflict environment, promising more than a government can deliver appears not only futile, but may have retarded some of the positive effects coming from the limited implementation of these policies. Upon reflecting on the implementation of Justice and Peace, Colombia's Ministry of Justice warns, "In the context of political transition, the promises made by the state must be fulfilled in order to guarantee the transition's stability, legitimacy, and durability. Justice and Peace has demonstrated that a failure to keep those promises has a high cost in terms of regaining both the victims' and the ex-combatants' trust in the administration of justice and in the state in general." $(2015,41)$ 


\section{Upholding Human Rights}

Theoretically, transitional justice has the ability to help instantiate new norms within a society and change behavior. (Sikkink 2011) Two key indicators that can tell us whether there has been a change in behavior are the level of political violence and protection of the victims following implementation of these transitional mechanisms. Within Colombia, the ability of transitional justice to instantiate new norms is suspect, largely because prior and new victims continue to be displaced and murdered. While the transitional policies are not to blame for this continued violence, the absence of the state in former conflict regions and the persistence of criminality prohibit transitional policies from delivering radical change as it relates to human rights.

According to the Political Terror Scale, which rates the level of political violence in a country on a scale of 1 (the best) to 5 (the worst), political violence has subsided some in accordance to the overall decline of the general conflict. From 1996 to 2004, Colombia was a five, i.e., political terror was prevalent throughout the entire country. With the demobilization of more than 31,000 paramilitaries and around 20,000 guerillas after 2003, Colombia improved slightly to a four from 2005-2010. Since 2011, Colombia has graduated to a three, except for 2013 when it jumped back to a four, and within the current environment, political violence may now only be common. (Gibney et al. 2016)

In 2015, Vanderbilt University’s Latin American Public Opinion Project (LAPOP) asked respondents in Colombian consolidation zones, i.e., areas previously prone to conflict but recently re-taken by the state, to gauge the performance of the government since 2005 in preventing mass violations of human rights. Fifty-seven percent noted that the state's response was very inefficient or inefficient. (2015, 61-62) A 
similar question, this time gauging citizen perceptions throughout all of Colombia, asked respondents if they strongly agreed that basic rights are protected by the political system. Before transitional justice began, $40 \%$ agreed with this statement, but after 2010 when there was 45\% support, a significant decline occurred. In 2013 and 2014 only $28 \%$ had confidence in the political system to protect their basic rights. (Ibid, 59-60) These findings are generally supported by a 2013 Latinobarometro poll that found 53\% of Colombians believe their government's performance on human rights is poor/very poor, whereas 39\% responded it was good and only 5\% very good.

Unfortunately, these public perceptions are tied to reality. Each year, dozens of victims and their leaders are targeted and killed. Moreover, the bandas criminales have created a dangerous environment for the most vulnerable. As early as 2006, the MAPP warned of the regrouping of demobilized paramilitaries in areas where former AUC units left. $\left(6^{\text {th }}\right.$ report, 10) One year later, the OAS mission to Colombia reported that residents in departments such as Narino, Choco and Putamayo, traditional zones of conflict, perceived no improvements in security because of the persistence of illegally-armed actors. The effect of these groups, according to international observers, is that victims are reluctant to participate in Justice and Peace proceedings for fear of retaliation. $\left(9^{\text {th }}\right.$ report, 12) For example, although the MAPP and GoC do not consider the BACRIM the reemergence of paramilitarism in Colombia, these new criminal groups consist of former demobilized paramilitaries. Thus, if victims are to participate in truth-telling initiatives or testify against paramilitary leaders in court, there is a real chance the BACRIM will retaliate. 
As the security situation in former and ongoing conflict regions continued to deteriorate, the MAPP reported in 2011, “...threats, intimidation, and murder have been an almost permanent fixture over the past six years. As the trials and restitution of lands have moved forward, some victims and leaders have become the target of threats, intimidation, and murder." (15 ${ }^{\text {th }}$ report, 2$)$ In fact, as new transitional justice initiatives were being introduced, principally the restitution of land, threats and assassinations of those seeking to return to their homes increased. (MAPP, $17^{\text {th }}$ report, 2) The GoC has enhanced its security program for the victims, but it has not been enough. From 2005 to 2011, 50 leaders for internally-displaced persons were killed, and in 2015 alone, 54 human rights and land defenders were murdered. (Lopez-Vidal 2012, 12 and MAPP $20^{\text {th }}$ report, 7) Moreover, within the last two years, the BACRIM have become powerful enough to begin mediating conflicts and controlling community affairs in some regions. (MAPP $20^{\text {th }}$ report, 23) Not only have the victims been targets, but a large number of demobilized have also not been protected. While some demobilized deaths are due to their continued involvement in illegal activities, others were threatened or killed for failing to join the BACRIM. As of 2015, 3,820 demobilized, more than $10 \%$ of the initial 31,000, have been killed. (Ibid, 23)

Fortunately, the prevalence of political violence related to Colombia's military appears to be declining. Colombians have reported to the MAPP that their military's behavior in following international humanitarian law is improving, and the MAPP has seen a steady increase in the state's attempt to reinsert itself into ungoverned spaces. $\left(20^{\text {th }}\right.$ report, 25-26) This attempt has, however, been insufficient. Programs offered by officials such as Senator Wolff to expand the state have not been adopted due to limited resources 
and a neglect for those outside of the cities. Even with a further de-escalation of the conflict as a result of the GoC/FARC peace agreement, the OAS observer mission wrote in its most recent report,

...communities located in the areas that have experienced the most intense armed conflict have not seen significant transformation in their realities following the implementation of measures that both the Colombian government and FARC - EP have approved to de-escalate confrontation as part of the dialogue process between the parties. The presence of elements that continue to affect the security of communities serves to deepen their pessimism about the real impact that these de-escalation measures have on their daily lives. For example, extortion remains a daily reality, even having increased over this period... (21 $1^{\text {st }}$ report, 22$)$

Subsequently, any quantitative measurement indicating improvements in human rights should be qualified. Yes, the overall level of political violence has subsided since 2005, but based upon the evidence and expert opinions, this is largely due to the removal of one of the main protagonists in the conflict, the AUC. Demobilizing more than 50,000 illegal combatants since the conflict began is sure to help reduce violence. Yet, the fact that victims continue to be targeted indicates that a widespread shift in norms and behaviors has yet to occur. This can be explained in part by the government's inability to fully reinsert its authority in former conflict zones, as well as the pull of lucrative criminal activities, namely drug trafficking. Throughout a range of interviews with GoC and international officials in Colombia, the overall sense is that Colombia is not prepared for the demobilization of the FARC and the ELN either. The state remains weak in remote areas where coca cultivation thrives, and some experts expect a significant number of demobilized guerillas to form their own BACRIM organizations. If this occurs, victims will continue to be vulnerable, and human rights will remain an aspiration. 


\section{Concluding Thoughts \& Recommendations}

The impact of transitional justice on the development of the rule of law in Colombia has been uneven. General amnesties used during the early 1990s for several guerilla groups were politically successful, but they did little to improve law and order and human rights. Although these early amnesties were domestically generated and implemented, the intensity of the conflict coupled with general lawlessness prevented any type of positive trickle-down effects to be realized. However, since 2002, Colombia's rule of law has been on a generally modest but steady rise. In accordance with Moller and Skanning (2014), as well as the statistical results presented in Chapter Two, part of the explanation for this increase involves changes in Colombia's economic and religious environments.

From the qualitative analysis, it was shown that the implementation of Law 1448, particularly its provisions for the restitution of dispossessed land has helped improve the protection of property rights. Furthermore, improvements to law and order, as well as a slight increase in the protection of human rights, can be attributed to the overall demobilization and amnesties afforded as part of the Justice and Peace process. Due to the removal and provisions of amnesty for more than 50,000 illegal paramilitary and guerilla combatants, the number of civilian deaths, kidnappings and general political violence have all subsided. While these are welcomed changes and recognizable achievements, this first serious wave of transitional justice should have theoretically done more.

Remembering that the Justice and Peace process, along with its subsequent transitional policies, is transitional justice within an ongoing conflict, it is still fair to 
question why more was not achieved considering the structure and promises of this approach. For instance, Law 975 was a sea change from Colombia's traditional policy of general amnesties and DDR agreements during the 1990s. These general DDR accords were replaced with laws that promised truth, justice, reparations and non-repetition. Additionally, for the first time in Colombia's processes of peace, victims' interests were considered and many of the mechanisms used came as a direct result of their lobbying efforts. Moreover, laws 975, 1448 and 1592, along with the Legal Framework for Peace, were all domestically generated and implemented. According to the theoretical expectations of the literature outlined in Chapter One, the domestic origination and execution of transitional justice should have set Colombia on the path to success. Additionally, Colombia utilized a "justice balance," namely it coupled retributive trials with restorative mechanisms, which according to earlier findings helped improve democracy and human rights. (Olsen, Payne and Reiter 2010) Yet, despite all of these advantages, the effect of transitional justice on the rule of law was minimal. Deep changes in the substantive domain were not found, such as normative or behavioral changes, and Justice and Peace did not produce widespread institutional efficiency and growth.

Two major phenomena help explain why radical reform did not follow Justice and Peace. First, problems with implementation left many promises of truth, justice, reparations and non-repetition unfulfilled. After five years, only two sentences had been handed-down, and the first judicial reparations were not awarded until 2011, six years after passage of Law 975. Even today, only a little more than 3,000 of the more than half a million Justice and Peace victims have received reparations through the courts, and only 
approximately one percent of the initial 5,000 demobilized that were to come before the courts were ever judicially processed. Moreover, half-way through implementation of 975, the government changed the framework of transitional justice, against the wishes of many, and put into place a new prosecutorial strategy that further limited criminal convictions, while also initially trying to limit reparations for many. As reflected in Latinobarometro and LAPOP opinion polling, these changes helped erode trust and the perceived performance of Colombia's judiciary.

Encapsulated within this challenge of implementation, this initial wave also excluded the state. Law 975 is not applicable to state crimes nor did it require truthtelling initiatives to take into account state crimes. The failure to include the state as part of this wave was a mistake that damaged the legitimacy of the process. The culpability of the state in war crimes and crimes against humanity came out in the false-positive and para-political scandals, as well as by the ICC. While thousands of brave and honorable Colombian soldiers and police have lost their lives during this five-decade long conflict, the sheer size and reach of both the army's killing of civilians and hundreds of government officials' ties to the paramilitaries indicates that these illegal behaviors were not isolated incidents. Fortunately, some steps have been taken to prosecute individuals responsible for these crimes, and as part of the implementation of the next wave of transitional justice agents of the state will have to account for their crimes within a special judicial tribunal and truth commission.

The second major impediment has been the existence of rule of law inhibiters. Many of these inhibiters are common during a conflict and post-conflict setting, and even with the best efforts, transitional justice is likely unable to penetrate the wall created by 
these obstacles. One of the primary inhibiters is the persistence of the general conflict itself. The Justice and Peace process began within a conflict environment; in 2005, the FARC and ELN both remained engaged in challenging the state militarily. In addition to military conflict, the failure of the state to fully reinsert its presence and govern former conflict regions has allowed criminality, drug trafficking and overall violence to persist.

The reporting from the international observer mission in Colombia has captured the emergence of the BACRIM, and the ability of these criminal gangs to kill, intimidate and prevent victims from taking part in all aspects of the Justice and Peace process. The failure to provide security is a clear violation of the government's pledge of nonrepetition. The third inhibiter identified helps explain why implementation and revictimization occurs. The lack of resources, both financial and institutional, inhibits a quicker resolution of judicial cases, threatens the solvency of both judicial and administrative reparations, and prevents the state from governing in all former conflict regions. In fact, despite having observed the BACRIM establish control over former AUC strongholds, Colombia's Attorney General warned the country that in the Department of Antioquia, the BACRIM group, El Clan del Golfo, is already offering financial incentives to demobilizing FARC to join their criminal ranks. This illegal group is also seeking to establish a presence in areas abandoned by the FARC as a result of their ongoing demobilization. (Vanguardia Liberal 2017, 8A)

The final rule of law inhibiter in Colombia is corruption. Along with their rule of law indicator, the WGI also produces a yearly measurement of corruption, which they define as the perception that public power is used for private gain. Unlike the positive trend in the rule of law, corruption is getting worse in Colombia. Despite improving at 
the turn of the century, corruption reached its pinnacle during 2010-13, as illustrated in Figure 3.3.

Figure 3.3: Perceived Level of Corruption in Colombia: 1996-2015

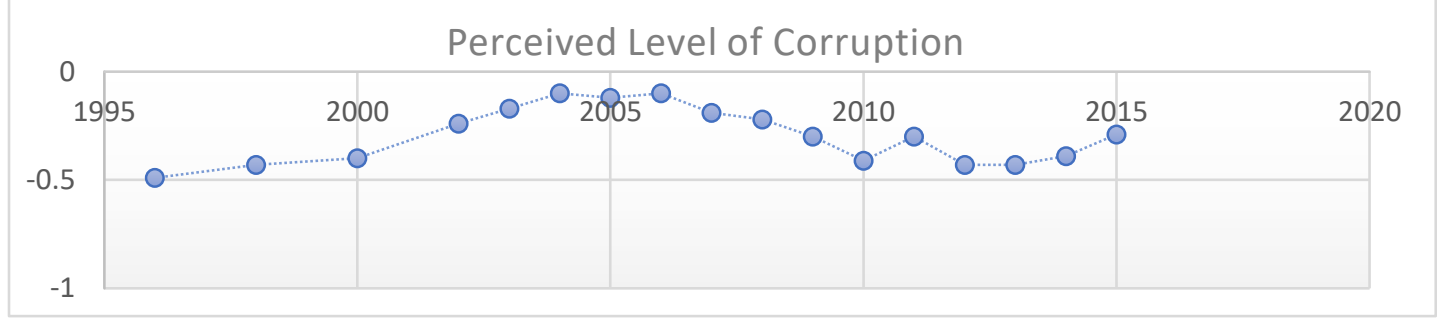

* Scores range from 2.5 (little corruption) to -2.5 (widespread corruption).

**Data is from the WGI measurement on corruption.

LAPOP surveys have captured a similar attitude. In 2005, 36\% of Colombians believed corruption to be widespread, yet by 2010 the number had risen to $54 \%$ and most recently to $60 \%(2014)$. $(2015,52)$ These public perceptions are being borne-out by current events. In January 2017, several Senators, Congressmen and President Uribe's former Vice Transport Minister were arrested for allegedly taking bribes to help the Brazilian engineering firm Odebrecht receive lucrative construction contracts in Colombia. (Maas 2017) The pervasiveness of state graft has reached a level that according to the country's Inspector General costs the government $\$ 7.5$ billion a year or roughly $10 \%$ of the government's 2017 budget. (Alsema 2016) In a conflict-affected state, the loss of almost $\$ 8$ billion a year is significant, particularly as it strains to meet its transitional justice demands and increase the capacity of its institutions.

In light of these inhibiters, Colombia needs to take action if this upcoming wave of transitional justice is to help promote the rule of law. Like its 975 cousin, this newer wave is comprehensive in that it includes elements of truth, justice and reparations. There will be a special tribunal to try guerillas and agents of the state, a truth commission and the administrative reparations under Law 1448 will continue. Yet, as has been shown, the 
democratic design and implementation of these mechanisms will not be enough to meet transitional justice's long-term aspirational goals. For this process to help develop the rule of law, the government must find a way to use both transitional justice and its ongoing development programs to expand the reach of the state. Getting paramilitaries and guerillas to demobilize is not enough; the security vacuum created by these demobilized groups allows existing criminal organizations, many of which are composed of former demobilized combatants, to use these areas for illegal enrichment and continued exploitation of the victims. Not only must the security forces remain in these regions, but other branches of government must follow. During an interview with one international diplomat in Colombia, this individual shared his assessment that in rural areas, institutions that promote the rule of law are generally absent. These institutions, such as the Fiscalia and courts, do not attempt to educate and include the indigenous and local communities in their organizations, and service in remote areas for those already in these agencies is a "career-killer." ${ }^{64}$ Whether this attitude and incentives will change is unclear, but if the state does not take-over these zones, criminality and violence will persist.

Although Colombia has a tradition of ignoring its rural areas, some efforts were undertaken recently to address this problem. First, under President Uribe, the GoC initiated a National Consolidation Plan in Uribe's second term that was to promote security, reduce the illegal drug trade, establish government services and jump-start economic development in rural regions. Initially, this plan aimed to reach 15 different

\footnotetext{
${ }^{64}$ International official in Colombia, interview, March 2, 2016, Bogota, Colombia.
} 
zones covering 100 municipalities. (Isaacson 2012) After President Uribe, President Santos, continued with consolidation, albeit at reduced levels. Under President Santos, the initial plan was reformulated and re-launched in November 2011 as the National Plan for Territorial Consolidation.

But, under Santos' initiative, the number of targeted municipalities was reduced from 100 to 58, and the consolidation budget was cut from 320 billion pesos in 2010 to 125 billion pesos in 2011 (from $\$ 108$ million to $\$ 42.5$ million). (Ibid) Since consolidation began while President Santos was Defense Minister, and one of the original architects of this policy, Sergillo Jaramillo now serves as Peace Commissioner, it is perplexing why this government significantly reduced this program. While I was unable to speak directly with officials that could answer this question, the reason may be tied to the ongoing peace talks. For instance, consolidation programs typically target areas where illegally-armed actors once served as the governing authority. Reducing the FARC's and ELN's influence in areas they hope will serve as their base of future political support was likely opposed by the guerillas before peace talks began.

Regardless of the reasoning for the reduction, a range of Colombian officials realize the $\mathrm{GoC}$ must enhance and renew consolidation efforts if these potential peace accords are to have a long-term effect. And, if transitional justice is to do more than merely determine guilt or innocence, the government must muster the political determination and dedicate the necessary resources to establish an enduring presence in areas traditionally neglected. Without this, the rule of law will not be experienced by those victimized, their reparations will be spent without prospects for sustainable subsistence and other powerful actors will fill the governing vacuum, potentially 
perpetuating the cycle of violence and victimization. Fortunately, for BiH and Kosovo, which are discussed in the next chapter, the absence of the state has not been an inhibiter to transitional justice and the rule of law, but rather, an equally powerful one, ethnicity, has prevented transitional mechanisms from playing a meaningful role in these Balkan states. 


\section{Introduction}

\section{Chapter 4 \\ BiH \& Kosovo: The Challenges of Ethnicity}

The relationship between transitional justice and the rule of law in Bosnia and Herzegovina $(\mathrm{BiH})$ and Kosovo is complicated. According to the results of Chapter Two, both countries' mean rule of law scores noticeably increased after these countries transitioned from an international to a mixed model of transitional justice, as illustrated in Figures 4.1 and 4.2. ${ }^{65}$ In addition to the differences in their mean rule of law scores before and after the introduction of a mixed model, the differences in means are statistically significant. In Chapter Two, the results were presented from the Independent Samples T-Tests for each set of means, which reported statistically significant differences at the .05 level. Yet, despite this apparent relationship, the regression analysis produced no statistically significant results for the rule of law in either model after controlling for alternative factors.

\section{Figure 4.1: The Rule of Law in Bosnia \& Herzegovina}

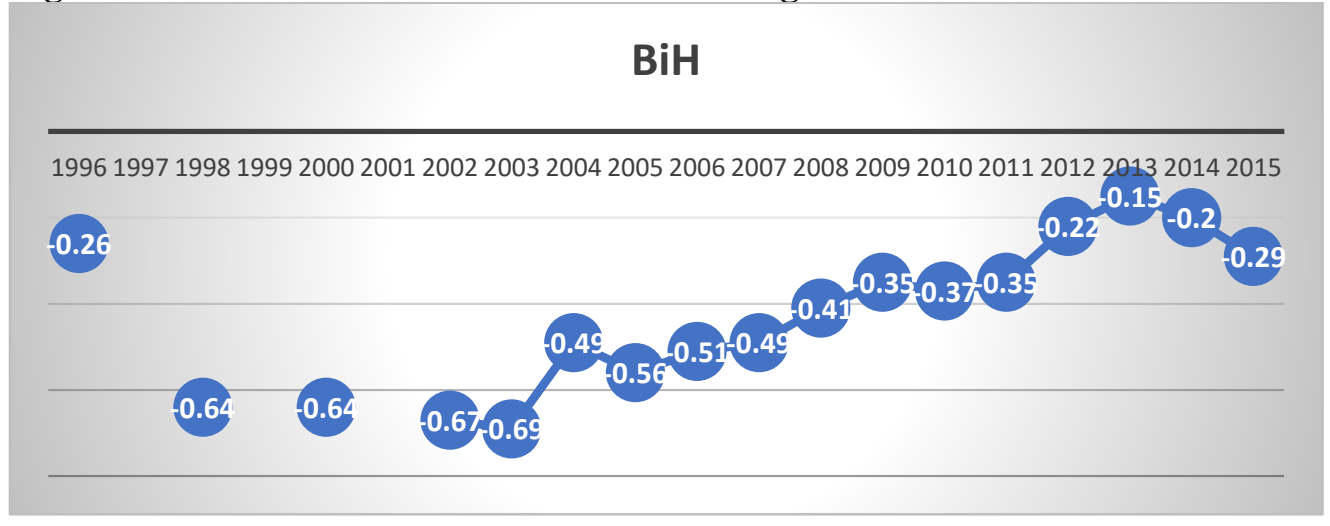

*Bosnia began using a mixed model in 2005.

\footnotetext{
${ }^{65}$ An international model of transitional justice occurs when the international community entirely develops and implements the mechanisms of transitional justice. A mixed model involves both international and domestic actors, and it is represented by a balance in the responsibilities to formulate and execute transitional policies.
} 
Figure 4.2: The Rule of Law in Kosovo

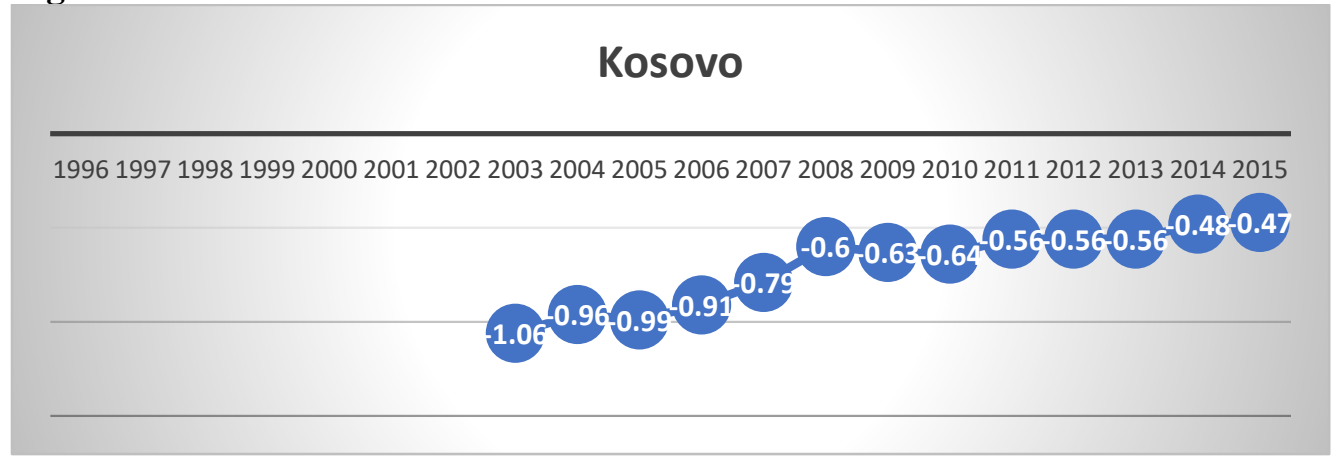

*Kosovo's switch to a mixed model occurred in 2008.

**Data for both figures is from the Worldwide Governance Indicators (WGI).

Subsequently, upon tracing the effects of transitional justice within Kleinfeld's five common ends goals for rule of law reform, the picture becomes clearer. While the international model employed in each country had its own drawbacks, the more detailed qualitative analysis supports the regression results, namely the mixed model has not been any more effective in developing the rule of law than was the international. Powerful rule of law inhibiters exist in both Balkan states, which create thick walls blocking the diffusion of many of the positive effects of transitional justice. The main inhibiter shared by both countries is the prioritization of ethnicity over dealing with the crimes of the past. Moreover, international and local emphasis on trials failed to provide a justice balance, and the growth of corruption also inhibited the diffusion of many potentially positive effects.

In order to help understand this complicated dynamic, 25 interviews were conducted in $\mathrm{BiH}$ and Kosovo during June of 2016. These interviews were held with international and local government officials, members of civil society and relevant incountry scholars. (See Appendix F for a list of general questions.) To help supplement these interviews, a series of reports from international institutions in both $\mathrm{BiH}$ and 
Kosovo were carefully studied. For $\mathrm{BiH}$, all 48 reports from the High Representative in BiH to the UN Secretary General (UNSYG) covering 1996-2015, along with all European Commission (EC) Progress Reports from 2005-2015, were reviewed. In relation to Kosovo, 51 of the UN Secretary General's quarterly Kosovo reports to the UN Security Council from 1999-2015 were examined, which since 2009 also include the European Union's assessment of the rule of law in Kosovo ${ }^{66}$ Other relevant international reports such as from the Organization for Security and Cooperation in Europe (OSCE) and the International Criminal Tribunal for the Former Yugoslavia (ICTY) were also reviewed as needed. All of these reports served as useful sources of information, and they enhanced the number of observations on both the rule of law and transitional justice variables.

To help the reader understand the powerful effects of ethnicity within these cases, this chapter is organized accordingly: the following section explains the various models of transitional justice used; section three describes how these models were designed and executed, including outlining how bias and a focus on trials influenced model design; next, the implementation of these models will be evaluated against the five end goals of the rule of law, pointing out in each where the aforementioned inhibiters emerged; and finally, the chapter concludes with some final observations.

\section{The Transitional Justice Framework}

Since the dissolution of the Socialist Federal Republic of Yugoslavia (SFRY) in 1991, a plethora of scholarly literature and crisis reports have emerged explaining the

\footnotetext{
${ }^{66}$ For citation purposes, reports from the High Representative are designated as OHR; these OHR reports were reviewed online and do not contain page numbers. European Commission reports are labeled EC, and UN reports on Kosovo are identified as UNSYG.
} 
reasons for its breakup, the tragedy of the conflicts that ensued and the organization and governance of the post-conflict periods ${ }^{67}$ Consequently, this analysis does not seek to replicate what has already been exhaustively covered, but it is useful to highlight the factors that precipitated the need for transitional justice. For instance, in $\mathrm{BiH} 150,000$ people were killed and another 170,000 injured during the fighting that ensued between Bosnia’s Croat, Serb and Bosniak communities from 1992-1995. ${ }^{68}$ Moreover, as a result of the conflict, more than two million people had been displaced, 25,000 women were raped, $60 \%-70 \%$ of homes and 1,600 religious sites were destroyed or damaged and 30,000 people were missing. ${ }^{69}$ (Kiza 2012, $249 \& 259$ ) The conflict in $\mathrm{BiH}$ is also notorious for the genocide that occurred in the town of Srebrenica during July of 1995 that took the lives of 8,000 Bosniak men and boys. Following this atrocity, the North Atlantic Treaty Organization (NATO) intervened and by November of that year Croatia, $\mathrm{BiH}$ and the Federal Republic of Yugoslavia (FRY) had signed the Dayton Peace Accords thereby ending approximately four years of fighting.

In addition to terminating the conflict, the Dayton Accords also established an internationally-led Office of the High Representative (OHR) charged with ensuring implementation of the peace agreement, which included the use of executive powers ("Bonn Powers") if local officials were not abiding by the terms of the accord. ${ }^{70}$

\footnotetext{
${ }^{67}$ The International Crisis Group has a series of reports detailing the wars in the Balkans, which can be found at https://www.crisisgroup.org/europe-central-asia/balkans.

68 The Bosniak community is predominantly Muslim, whereas the Croat and Serb populations are Christian/Orthodox.

69 The Association of Women Victims of the War, interview, June 9, 2016, Sarajevo, BiH.

${ }^{70} \mathrm{OHR}$ is funded primarily by the EU and United States, and its political support and guidance comes from the Peace Implementation Council Steering Board, which includes the United States, Russia and several
} 
Moreover, Dayton created a federated Bosnian state dividing the country into two entities, the predominantly Serbian Republika Srpska (RS) and the largely Muslim and Croat Federation of Bosnia and Herzegovina (hereafter the Federation). Within the Federation, there are 10 separate cantons, and in additions to these divisions, the district of Brcko also enjoys significant governing autonomy outside of either the Federation or the RS. Subsequently, implementation of transitional justice has been challenging, particularly since there is a state court, 10 cantonal courts in the Federation, five district courts in the RS and a court in Brcko all with jurisdiction for war crimes.

Kosovo's internal conflict, which lasted from 1998-99, centered around the onetime Serbian province's desire to be independent after the heavy-handed rule of Slobodan Milosevic. While part of the SFRY, Kosovo enjoyed a high degree of autonomy, but once Serbia revoked much of that autonomy in 1989, the impulse for independence grew within the dominant ethnic Albanian community. By 1998, the Kosovo Liberation Army (KLA) was engaged in a conflict with forces from the FRY and Serbia. As a result of this violence, approximately 13,000 people were killed, and more than half of Kosovo’s 1.7 million people were displaced. ${ }^{71}$ (Di Lellio and McCurn 2012, 133)

In order to prevent the same level of destruction in Kosovo as had taken place in $\mathrm{BiH}$, the international community intervened more quickly, primarily through NATO bombardment of Serb forces, and by June of 1999 governing authority for Kosovo had been transferred to the United Nations (UN) under UN Security Council Resolution 1244

Western European nations. Although now smaller and more limited in its activities, OHR still operates in $\mathrm{BiH}$.

${ }^{71}$ The UN estimated that 800,000 Kosovars were refugees and another 500,000 were internally displaced during the 1998-1999 period. (UNSYG July 12, 1999, 3) 
(1999). UN Security Council Resolution (UNSCR) 1244 (hereafter 1244) established an interim, UN-led administration designed to govern Kosovo until its future status was decided, which after several years of fruitless negotiations between Serbia and Kosovo resulted in Kosovo unilaterally declaring independence in 2008 with the support of the United States and key European nations. ${ }^{72}$ As part of their declaration of independence, Kosovo agreed to limited, continued international oversight, which included the deployment of the European Union Rule of Law Mission to Kosovo (EULEX), whose current mandate expires in June of 2018.

In light of the widespread human rights abuses that were occurring as part of the dissolution of the SFRY, the UN Security Council established the International Criminal Tribunal for the Former Yugoslavia through UN Security Council Resolution 827 (1993) in order to prosecute serious violations of international criminal law occurring in this region of the world. As part of the terms of both Dayton and 1244, $\mathrm{BiH}$ and Kosovo are obligated to cooperate with this tribunal. Throughout the former Yugoslavia, the ICTY operates under the principle of concurrent jurisdiction with domestic courts, although the ICTY statute does allow it to take-over any case in the pursuit of international justice. ${ }^{73}$ While not created only for $\mathrm{BiH}$, approximately $80 \%$ of the 161 indictments it issued were related to the conflict in this Balkan state. (Kiza, 252) In fact, the ICTY's first indictments and trials involved two Bosnian Serbs in 1994 and 1996 respectively, and its last trial, which is currently ongoing, involves former Bosnian Serb leader Ratko Mladic.

\footnotetext{
72 As of March 29, 2017, 113 countries had recognized the Republic of Kosovo, although Serbia has still not formally recognized Kosovo’s independence. (Republic of Kosovo, Ministry of Foreign Affairs)

${ }^{73}$ Concurrent jurisdiction technically provides both the ICTY and local courts jurisdiction in war crime cases, although in practice, the ICTY was the preeminent institution for many years.
} 
Since it first started its investigations in Kosovo in 1999, the ICTY has completed all of its cases against the 15 individuals, both Serbian and Kosovar, indicted for Kosovo related war crimes, which included issuing indictments against a sitting president (Slobodan Milosevic) and prime minister (Ramush Haradinaj). The current international transitional justice structure in Kosovo centers around the recently-established Specialist Chambers in The Hague, Netherlands. This international tribunal has the authority to investigate and prosecute post-1999 crimes committed by the KLA, which includes allegations of harvesting the organs of some of its prisoners. ${ }^{74}$ (UNSYG August 1, 2014, 20)

While the ICTY has been operating since 1993, both Kosovo and BiH have also employed domestic trials. For instance, during the conflict, some Bosnian courts conducted trials for war crimes, although these were generally dismissed for being ethnically biased. (Orentlicher 2010, 109) Despite Kosovo not having much of a judiciary during its conflict, seven war crimes cases were carried out locally from 1999-2000, but here too, four of these convictions were later overturned by international panels of judges. To help mitigate local bias, the international community required Bosnian prosecutors to first obtain ICTY approval for any war crimes arrests. This policy, which was labeled Rules of the Road, was in effect from 1996 until 2004; of the 4,985 names submitted to the ICTY, approval was given for 848 arrests. (Ibid, 110-11)

In Kosovo, bias was addressed differently. As part of its executive authorities, the UNMIK Special Representative of the Secretary General in Kosovo (the SRSG) began

\footnotetext{
${ }^{74}$ According to the EU's former special prosecutor, the Specialist Chambers' jurisdiction begins in Kosovo when the ICTY's mandate ends, i.e., June of 1999. (UNSYG August 1, 2014, 21)
} 
appointing international judges and prosecutors in 2000 to adjudicate war crimes cases within local courts. These cases were heard by mixed panels of judges, with the majority being international, and by 2002, there were 27 international judges and prosecutors working throughout Kosovo. (UNSYG July 17, 2002, 5) This initial hybrid system, whereby international judges and prosecutors worked within local courts, was, however, not the UN's or Kosovo's original choice. In his report to the Security Council of March 3, 2000, the Secretary General asked member states to provide financial and personnel support for a hybrid Kosovo War and Ethnic Crimes Court. (25) This court did not however enjoy enough international support, and as a result, UNMIK continued to rely on international judges, prosecutors and investigators to handle war crimes cases within the existing court structure. In December 2008, as part of the post-independence arrangements, authority for all war crimes cases was transferred to EULEX, which has also opted to use a hybrid system.

Despite the fact that a dedicated war crimes tribunal was not adopted in Kosovo, this idea was embraced in BiH. In 2005, following the urgings of OHR and the ICTY, the War Crimes Chamber (WCC) was established within BiH's State Court. The WCC operated as a hybrid tribunal from its inception until the end of 2012, and it has the charge of handling the most complex war crimes cases. Less serious ones are being adjudicated by local courts, in accordance with BiH's War Crime Strategy of 2008, which set the target dates of 2015 and 2023 to complete all complex cases first and all 
remaining cases last. ${ }^{75}$ As will be discussed, $\mathrm{BiH}$ failed to meet its 2015 deadline, but it has finished adjudicating all 10 cases transferred to the WCC from the ICTY.

Examining this panoply of retributive mechanisms, $\mathrm{BiH}$ and Kosovo have utilized a range of international, hybrid and domestic trials. ${ }^{76}$ The ICTY remains active in prosecuting Bosnian-related cases, but beginning in 2013, this country's WCC transformed into a fully domestic court, which is complemented by a range of war crimes trials at the local level. Despite its independence, Kosovo is still using international (Specialist Chambers) and hybrid trials for its remaining cases. The "judicial training wheels" have yet to come off for Kosovo, and substantial authority for accountability proceedings still rests with EULEX. Yet, despite the emphasis on trials, several other mechanisms have been used, albeit in limited ways.

Although there is some local civil society and international support for a regional truth commission for the former Yugoslavia (known by its acronym RECOM - Regional Commission on Establishing the Facts on War Crimes and Grave Violations of Human Rights in the Former Yugoslavia), neither BiH nor Kosovo have officially signed-on, nor have they utilized their own truth commissions. For reasons that will be discussed later, Kosovo has generally avoided any attempts at establishing an historical record of events, and while $\mathrm{BiH}$ has attempted two separate truth-telling initiatives, these were limited in scope and effect. For instance, a mixed international/RS Commission on Srebrenica did release a report on events in this $\mathrm{BiH}$ town in June 2004, but attempts to produce a

\footnotetext{
${ }^{75}$ This strategy is a prosecutorial and not a comprehensive transitional justice strategy.

${ }^{76} \mathrm{BiH}$ also filed suit against Serbia in the International Court of Justice, which ruled in 2007 that Serbia was not directly responsible for genocide in $\mathrm{BiH}$, only Bosnian Serbs. This verdict angered many Bosniaks.
} 
similar product covering the siege of Sarajevo did not bear fruit. ${ }^{77}$ In addition to these bodies, there were two efforts for a Bosnian-wide truth commission, but neither attempt made it past a draft law owing to the lack of international and local political support. (Dragovic-Soso 2016, 8-10)

Out of the remaining three mechanisms that are part of this analysis, amnesty has not been used, which is not surprising considering the emphasis on accountability. Lustration, which in these cases more closely resembles vetting, has been done. The first round of judicial vetting in Kosovo was conducted by UNMIK in 2001; seven years later, the vetting was more formal. In 2008, UNMIK established the Independent Judicial and Prosecutorial Commission, which was an autonomous, temporary body within the Kosovo Judicial Council created specifically to oversee the vetting of all judges and prosecutors. With the financial support of the European Commission and United States, 334 judges and prosecutors were either reappointed or newly hired as part of this 2008 review. (UNSYG March 13, 2001, 9, UNDP 2012, 36) Later, under its mandate, EULEX conducted its own round of judicial vetting in 2010. (UNSYG July 29, 2010, 16) A similar program was utilized by OHR in 2004 when after its vetting $20 \%$ of judges and prosecutors were removed and replaced. (EC 2005, 17)

While victims in both countries deserve and need a comprehensive reparations program, efforts at restorative justice have been limited to property restitution. In 2000, the Housing and Property Directorate (HPD) was established in Kosovo under the authority of UNMIK to resolve residential property claims, and a similar commission

\footnotetext{
${ }^{77}$ Although a Sarajevo-focused truth commission was established under the Ministry of Human Rights and Refugees in 2006, this body dissolved in only a year without producing a report due to ethnic disagreements. (Subotic 2009, 149-50)
} 
(Commission on Real Property Claims for Displaced Persons and Refugees) was created in $\mathrm{BiH}$. In terms of providing monetary compensation to victims, little has been done. While there are laws on the missing in both $\mathrm{BiH}$ and Kosovo, which for instance requires the Kosovo government to pay for things like burial costs once the missing are identified, neither state has a comprehensive reparations program for the majority of its victims, i.e., there has been no tangible acknowledgement of harm or efforts to restore victims to their pre-war state. Moreover, if the governments do dispense with some type of financial remuneration, it is usually packaged as pensions or other forms of social assistance.

To review, both $\mathrm{BiH}$ and Kosovo have pursued a trial-heavy approach to transitional justice, although much of it has been dictated by the international community. Initial domestic trials were replete with bias, but varying hybrid systems have been and are being utilized to some effect. This focus on retributive justice has unfortunately prevented other mechanisms from being fully realized. There has been no serious effort at establishing truth, although ICTY trials have helped, and financial reparations for hundreds of thousands of victims have generally been forgotten or are too costly. The willingness to forgive and forget through any type of amnesty program has also been conspicuously absent. Restitution of property has been emphasized, as was the vetting of judicial personnel, but here too, the international community was the initiator and implementer of these reforms.

In light of these shortcomings and despite the length of time that has transpired since the termination of the conflicts, both states are now working on their own comprehensive transitional justice strategy, albeit haltingly. As part of these strategies, programs are envisioned that would reform institutions, establish truth and provide 
comprehensive reparations. Unfortunately, these strategies have been discussed for several years, and the lack of domestic political support for them is delaying their adoption. Yet, as part of both countries EU accession processes, proponents of these policies are hopeful international pressure will persuade local leaders to adopt comprehensive transitional justice policies. ${ }^{78}$

Since these strategies are only in the development stage, they will not be part of this analysis. But, for $\mathrm{BiH}$ what is included is its use of a full range of trials, limited truthtelling, reparations and lustration, whereas Kosovo's transitional justice will be measured based upon international and hybrid trials along with lustration and reparations. Categorizing these mechanisms by year and model, as found in Annex B, was challenging. Due to the mix of international governance and developing domestic institutions, labeling these formulas according to this study's international, mixed or domestic schema was difficult. However, based upon the definitions provided for these three models in Chapter Two, it is important to recall that the basis for determining a mixed model is the balance between the international community's and local government's responsibilities in the design and execution of the various mechanisms. $\mathrm{BiH}$ was able to move to a mixed model in 2005 following the creation of its War Crimes Chamber, and although hybrid judicial panels began in Kosovo as early as 2000, a true shared commitment to transitional justice was not in place until after its independence in 2008. How the international community and each country arrived at their respective formulas is explained next.

\footnotetext{
${ }^{78}$ Bosnian Ministry of Human Rights and Refugees, interview, June 10, 2016, Sarajevo, BiH. Bekim Blakaj, Humanitarian Law Center Pristina, interview, June 20, 2016, Pristina, Kosovo.
} 


\section{Model Design: International Imposition to a Balanced Approach}

Within the transitional justice literature, it is theorized that those transitional processes domestically designed and implemented will be more effective in ushering-in meaningful changes as opposed to those internationally imposed. (Lambourne 2009, 31, 33, Stromseth, Wippman, and Brooks 2006, chap. 7, Turner 2008) As was already mentioned in the introduction to this chapter, while the descriptive statistics indicate a difference in models, the regression and qualitative analyses do not. Yet, understanding how the various mechanisms of transitional justice were developed and executed remains important, particularly since it describes why a justice balance was never used. Moreover, the imposition of the international models helps illustrate the problems of ethnic bias in both $\mathrm{BiH}$ and Kosovo.

In order to understand the initial ICTY-centered approach, it is helpful to take note of the moment, both domestically and internationally, during which time this tribunal emerged. According to Sikkink, the ICTY was an important component within the emerging Justice Cascade, which is the culmination of international and domestic political forces that have established the global norm of individual criminal accountability for violations of international humanitarian law. (2011) Moreover, as Fletcher, Weinstein and Rowen note, when the international community intervenes in a weak state it will typically dictate which transitional mechanisms are used, which usually involves some type of accountability proceeding. $(2009,201,209)$ In addition to the presence and spread of the accountability norm, an international court was imposed because the international community was not convinced the local courts could try war crimes cases fairly. 
For example, Kerr contends, “...the intention was not to preclude the exercise of jurisdiction by national courts. Rather, it was to ensure that the Tribunal had the power to command deferral of cases in national courts, if it saw fit, and to permit those cases to go ahead in national courts, where appropriate." $(2004,66)$ Under the ICTY's Rules of the Road, which oversaw Bosnian war crimes prosecutions for almost a decade, the ICTY had final say on who could be prosecuted locally from 1996 until 2004. The genesis for this program, according to OHR, was to help stop arbitrary arrests based on ethnicity in both of the entities. (OHR July 10, 1996)

While the ICTY did not officially have a Rules of the Road policy with Kosovo, domestic war crimes prosecutions were also tightly controlled by the international community. The practice of UNMIK placing international judicial officials at the center of war crimes cases began in 2000. Early on however, UNMIK appointed local judges and prosecutors to temporary courts in 1999, but after bias emerged, the SRSG used internationally-led judicial panels consisting of two international judges alongside one local counterpart. Moreover, prosecutions were done by international attorneys. UNMIK's control over war crimes cases continued throughout its rule of law mandate (1999-2008). For instance, although the UN reported in April 2002 that most of the international police units in Kosovo had been integrated with local police, the war crimes unit had not; additionally, the first local war crimes indictment against the KLA was issued by an international prosecutor. (UNSYG April 22, 2002, 6, UNSYG January 29, 2003, 9) When oversight of the Kosovo Police Service was transferred to local control in 2006, UNMIK did not include the war crimes unit or witness protection, and when the Kosovo Special Prosecutor's Office was established a year later, war crimes was 
conspicuously absent from its charge. (UNSYG June 5, 2006, 13, UNSYG June 29, 2007, 12)

In addition to the aforementioned factors supporting international control of trials, there were also practical realities that favored an initially heavy-handed international approach. In his first Kosovo report, the UN Secretary General explained that there was an institutional void in Kosovo's judiciary. Following the war, all Kosovo Serb judges and prosecutors fled the province over fears of retribution, and most of the legally-trained Kosovo Albanians had either not yet returned from being displaced or were not qualified to take-on complicated war crimes cases. (UNSYG July 12, 1999, 4, UNSYG September $18,2000,9)$ In $\mathrm{BiH}$, a similar reality was faced; in 1995, $\mathrm{BiH}$ and $\mathrm{OHR}$ had to rebuild the judiciary from scratch as many of the former judges and prosecutors had either been killed during the conflict or left the country altogether. (Kiza, 250)

The international monopolization of transitional justice was not only in the judicial realm. Part of the reason a truth commission was never established in $\mathrm{BiH}$ involved ICTY concerns that this body would be a competitor for international resources and local witnesses. (Subotic 2009, 146-48) Yet, despite the absence of a truth commission, both OHR and UNMIK carried-out a series of vettings and returned residential property due to a lack of local political will to undertake either of these initiatives. Consequently, the model that emerged early on, many times out of necessity, was imposition of justice, lustration and the return of property by the international community. There was little to no domestic input into the design of these mechanisms, and local officials did not have shared responsibility for implementing these programs. 
Without international action, it is likely little would have been done on transitional justice, or at the very least, it would not have been done well.

However, after approximately 10 years of international imposition, responsibilities in transitional justice began to be slowly devolved to local institutions. In $\mathrm{BiH}$, the need to establish a local successor to the ICTY spurred OHR and the tribunal to create a Bosnian-based war crimes court as part of the ICTY's completion strategy. According to its original plan, this international tribunal was designed only to try the most serious cases involving senior officials; the ICTY's temporary nature precluded this court from trying every individual responsible for war crimes from the former Yugoslavia. In $\mathrm{BiH}$ alone, there have been approximately 1,500 local convictions or indictments for war crimes, a judicial burden no ad-hoc international court is prepared to assume. (EC 2016, 27) Consequently, in 2002, after consultations with relevant local and international stakeholders, OHR recommended and the Peace Implementation Council (PIC) approved the creation of the War Crimes Chamber within the Bosnian State Court, which became operational in 2005. (OHR March 5, 2002 and OHR October 13, 2003)

Although the idea for the WCC came from the international community largely out of necessity, since its inception Bosnian officials have taken greater ownership of it. In the beginning, the court was a hybrid; in 2005, panels of two international judges worked alongside one local. By 2008, the balance had shifted to 2 local judges alongside one international. (International Center for Transitional Justice 2009, 4) In fact, when the original mandate for the international judges and prosecutors expired in 2010, many local Bosnian judicial officials requested extensions for the international judicial officials, which led to the High Representative extending their mandates through 2012. Presently, 
there are no international judges or prosecutors within the WCC or Special Prosecutor's Office.

While EULEX has continued to use hybrid judicial panels, it has also slowly shifted more operational responsibilities for war crimes cases to local institutions following Kosovo's independence. In 2009, UN reports make their first mention of the Kosovo police beginning to assist in war crimes investigations, and by 2013, EULEX had reported that local and international prosecutors were investigating 100 war crimes cases. (EULEX 2013) The fact that local authorities have assumed some responsibilities for sensitive criminal cases does not mean the balance has completely shifted to local control, as in $\mathrm{BiH}$. For instance, after the Council of Europe published in 2010 a report on KLA war crimes, EULEX and an international prosecutor investigated these allegations, eventually leading to the international Specialist Chambers. When international and Kosovar officials were asked about the Specialist Chambers, all interlocutors agreed that its creation was imposed by the EU and United States, and its location in The Hague is due to the high level of local political influence within the courts, concerns over witness protection and a lack of local capacity to prosecute these cases. ${ }^{79}$

Additionally, according to both EULEX and the OSCE, more Kosovar involvement in local war crimes cases has not occurred because local judicial officials fear for their safety and undergo intense social pressure not to prosecute former KLA members. (OSCE 2010, 26) In fact, in one EULEX report, one local judge asked to have his name removed from the minutes of the court records in a sensitive war crimes case.

\footnotetext{
${ }^{79}$ International official, interview, June 14, 2016, Pristina, Kosovo.

Transitional Justice consultant to the Government of Kosovo, interview, June 20, 2016, Pristina, Kosovo.
} 
When this request was denied, the judge went on television to disassociate himself from the verdict. $(2010,31)$ Yet, while EULEX may still retain a great amount of authority in these types of cases, there is more of a balance than before independence. Moreover, like BiH, Kosovo’s government, along with civil society, are responsible for drafting their own comprehensive transitional justice strategy, and both countries now have their own prosecutorial and judicial councils that appoint and conduct disciplinary proceedings for all local judges and prosecutors.

It would be incomplete, however, to end this discussion on the why and how of mechanism selection without also highlighting the role ethnic politics played in these choices. Although initial ICTY resistance to a Bosnian truth commission has been noted, a Bosnian official also admitted that any type of fact-finding remains too difficult considering the lingering ethnic polarization among the various communities. ${ }^{80} \mathrm{~A}$ representative in the Ombudsman's office added that local support for a truth commission has subsided because many Bosnians fear this will lead to amnesties, and they also do not want a commission to produce a report that may equate victim suffering. ${ }^{81}$ Similar attitudes are found in Kosovo where due to Serbia's failure to apologize for its part in the conflict, many Kosovars are hesitant to support any regional truth initiative that includes officials from Serbia or would equate the suffering of Kosovo's Albanian and Serbian communities. (Di Lellio and McCurn, 132, 140)

In Kosovo, independence and ethnicity have also mixed to hinder the rate of Kosovo's assumption of judicial responsibilities and activities in northern Kosovo.

\footnotetext{
${ }^{80}$ Interview, supra n 78.

${ }^{81}$ Bosnian Human Rights Ombudsman's Office, Interview, June 4, 2016, Sarajevo, BiH.
} 
Before Kosovo's unilateral declaration of independence, EULEX was preparing for a less robust mission, but in light of some EU members' refusal to recognize Kosovo, along with Serbia's rejection of the declaration, EULEX was required to change its mandate from monitoring, mentoring and advising to one with more executive authorities. (HylkeDijkstra 2011, 197-99) Status sensitivities have also kept Kosovar officials from adjudicating war crimes cases in the ethnically-divided and contested region of northern Kosovo. Here, international judges and prosecutors remain the only judicial personnel carrying out sensitive cases because of the Kosovo Serbs' refusal to accept Pristina's authority in these matters. (UNSYG April 27, 2015, 12)

Consequently, the processes of mechanism design and implementation are complicated. International imposition of the ICTY by the Security Council was a result of international factors, but also based on the reality of biased and initially weak judiciaries. International hegemony in accountability proceedings persisted for many years, and the transfer of responsibilities did not begin until the need arose. A more balanced approach, i.e., utilizing a truth commission alongside trials or offering amnesties, was never seriously considered, largely due to deep ethnic divides and the international preoccupation with justice. While understanding the influence of international and domestic factors helps explain the why and how of mechanism design and implementation, it is also important to ask whether these models reflect the wants and needs of the people of $\mathrm{BiH}$ and Kosovo.

Interestingly, opinion polling shows that citizens in both states prioritize accountability over other mechanisms. In Kosovo, 90\% of respondents in 2007 believed punishing war crimes perpetrators was important; prioritization of trials was also evident 
in a 2014 Kosovo survey where when asked what is the best way to reveal the truth regarding the conflict, $30 \%$ (the highest category chosen) stated that trials/courts were the best option, whereas an international truth commission came in second with only $13 \%$. (UNDP 2007, 21, UNDP 2014, 20) Similar levels of support for trials were also found in BiH. According to a 2010 United Nations Development Program (UNDP) poll, justice for the victims was the number one choice of mechanisms for inclusion in any transitional justice strategy according to Bosnian respondents. $(2011,21)$ Although it is clear that many in $\mathrm{BiH}$ and Kosovo support trials, it is not clear whether this is due to a deep desire for retribution, or many are not educated about alternative choices. For example, in the same Bosnian poll, $61 \%$ admitted they did not know what a truth commission was. (Ibid, 25)

In regards to support for the ICTY, this depends almost entirely upon ethnicity. Overall, general support for the international tribunal is high within Kosovo, typically the highest of any country in the region. In 2004, 66\% of Kosovars supported the statement that the ICTY is the proper jurisdiction for war crimes cases; by 2006, $86 \%$ of Kosovars supported extraditions to the ICTY to further peace and by $201193 \%$ believed the same. (Ivkovich and Hagan 2009, 48 and Gallup Balkan Monitor) But, while there is support for the Tribunal in Kosovo, it is not uniform. When asked in 2012 if the ICTY meets international standards, only $1 \%$ of Kosovo Serbs agreed, which is a steep decline from the $30 \%$ of support Kosovo Serbs had given the court in 2007. (UNDP 2012, 15-17) Bosnian Serbs also do not believe in the impartiality of the ICTY. When asked if they had confidence in the tribunal, out of the $23 \%$ that did in $\mathrm{BiH}$, only $7 \%$ were Bosnian Serbs. (UN Resident Coordinator's Office in Bosnia and Herzegovina 2013, 46) 
Clearly, Serb support for the ICTY, whether in Serbia, BiH or Kosovo, is weak, particularly since it is viewed as a tool of victor's justice by many Serb people. For instance, this belief is fueled by the facts that two-thirds of the ICTY-indictees are of Serb origin, and only two Kosovar Albanians were ever convicted by this ad-hoc tribunal. ${ }^{82}$ Yet, while there was initially strong Bosniak endorsement for the ICTY, this too is declining due to judicial decisions this community views as unfair. In $2000,78 \%$ of the residents of Sarajevo agreed that the ICTY was the proper jurisdiction for war crimes, but only three years later, this level of support declined to 44\%. (Ivkovich and Hagan, 48) During a series of interviews, representatives of Bosniak-based victims' organizations acknowledged that the court was helpful, namely it prosecuted individuals that might not have otherwise stood trial, but recent court actions have eroded trust. One victim and now leader of an organization that represents victims from Srebrenica stated that the ICTY's acquittal of Serbian leader Vojislav Seselj was "outrageous," and she noted that the International Court of Justice's failure to convict Serbia of genocide was even more upsetting. ${ }^{83}$

In terms of support for others mechanisms of transitional justice, there are clearly strong desires within societies for their governments to do more. Eighty-eight percent of Bosnians believe their government should develop a strategy for confronting the past and providing the truth, and $81 \%$ note that the conflict's victims have been abandoned or

\footnotetext{
${ }^{82}$ Haradin Bala and Lahi Brahimaj are the two Kosovo Albanians convicted and sentenced to prison by the ICTY. Four other Kosovo Albanians stood trial at the ICTY but were acquitted.

${ }^{83}$ Many Bosniaks blame the ICTY for the ICJ's verdict. The ICTY refused to share some FRY government documents with the ICJ due to this ad-hoc tribunal's desire to protect the national security of Serbia. Munira Subasic, Head of the Movement of Mothers of Srbrenica and Zepa, interview, June 10, 2016, Sarajevo, BiH.
} 
current attempts to remedy their situations have been insufficient. (UNDP 2011, 21, 29) In Kosovo, $95 \%$ support finding the truth, $81 \%$ believe all victims should receive material compensation and 73\% endorse removing or barring from public office politicians involved in former abusive behaviors. (UNDP 2012, 22, 26 and 29)

Considering these opinions, it is important to note that in transitional environments courts can only do so much. The ICTY indicted only 161 individuals, and Bosnian judicial proceedings, while laudable, led to the indictment of approximately 1,500 people out of a country where close to 200,000 died, 170,000 were injured and millions were displaced. Due to its nature, trials in post-conflict states have difficulty reaching everyone. When asked whether they or their family had direct experience with the ICTY or local war crimes cases, $96 \%$ of Bosnians replied that they have had no involvement with these courts. (UN Resident Coordinator's Office in Bosnia and Herzegovina, 29) Subsequently, while Bosnians and Kosovars support justice, they also want and need more.

For Olsen, Payne and Reiter (2010) these desires for a justice balance are not surprising. Recall that in relation to democracy and human rights, the aforementioned scholars find that in order for transitional justice to have a positive effect on these two areas, there must be a justice balance. For instance, trials or a truth commission alone will not promote democracy or human rights; trials need to be accompanied by a restorative element, such as amnesties. (Ibid) The international models used in BiH and Kosovo did not couple trials with amnesties or a truth commission, and attempts at reparations were limited. While a justice balance for the rule of law was not part of the Olsen, et al.'s, study, it is logically consistent to expect the same for this other area as well. 
Putting aside the absence of a justice balance for now, theoretically, the enhanced responsibilities for the design and execution of their respective transitional mechanisms should have helped transitional justice play a more meaningful role in both $\mathrm{BiH}$ and Kosovo. Bosnia has had more control over its transitional policies since 2005 , and after independence in 2008, the international community has slowly given Kosovars more responsibilities. Based on a statistical comparison of means, these assumptions appear valid. Unfortunately, the permeation of a radicalized ethnic ideology, coupled with an over-reliance on trials, continue to impede potentially positive effects of transitional justice, whether under an international or mixed model.

\section{Transitional Justice \& Its Effects}

Before launching an assessment of the effects of transitional justice in $\mathrm{BiH}$ and Kosovo against Klienfeld's five end goals of rule of law reform, it is important to first establish a baseline of the rule of law before the start of transitional justice. Since the WGI does not provide a measurement for either of these two countries before transitional mechanisms began, data on the state of the rule of law is taken from OHR and UN reports. Overall, during each country's respective conflicts, the rule of law was generally absent. Approximately 200,000 people were killed, at least another 200,000 injured, millions were displaced and the destruction of personal and religious property was commonplace. Moreover, in $\mathrm{BiH}$ genocide occurred. In addition to the violence, institutions that protect the rule of law crumpled. In its first report on Kosovo, the UNSYG noted that there were no local police, the judiciary was not functioning and in some areas there was "lawlessness." (July 12, 1999, 2, 4) Although the institutional void was not as deep in $\mathrm{BiH}$, this country's first post-conflict year included both entities 
refusing to release their prisoners of war, arbitrary arrests based on ethnicity were being made, property rights were ignored and there were regular police beatings and torture of prisoners. (OHR, July 10, 1996, October 1, 1996 and December 10, 1996)

While it is difficult to assign a numerical score for each country's rule of law during and immediately following their conflicts, it is helpful to recall that three years after the cessation of violence in Kosovo, the WGI assessed the rule of law to be extremely poor (-1.06); Bosnia’s first representative score, a -0.64 in 1998 also signifies a country struggling to establish a nation governed by the law. Subsequently, against this backdrop, transitional justice was introduced.

\section{Government Subordinate to the Law \& Equality of All Before the Law}

Theoretically, these two end goals of rule of law reform should have improved dramatically in the trial-rich transitional environments of $\mathrm{BiH}$ and Kosovo. Many of the architects of the war crimes, including presidents, prime ministers and generals, were sent to the ICTY, and those that carried-out the orders have also been prosecuted in hundreds of local war crimes trials throughout $\mathrm{BiH}$ and Kosovo. Therefore, what much of the transitional justice literature expects from trials, primarily that they will reinforce the equality of all before the law, should be found in these two Balkan states. (Olsen, Payne and Reiter 2010, 133) Unfortunately, contrary to expectations, the widespread use of trials did little to promote these two end goals. The focus on ethnicity and ethnic politics diluted the effects of the trials, at least for now.

The data, both quantitative and qualitative, is in overwhelming agreement regarding the absence of governments subordinate to the law and that promote the equality of all before it. According to the Bertelsmann Transformation Index (BTI), both 
$\mathrm{BiH}$ and Kosovo struggle to prosecute abuse of public office. Bosnia's initial score in this area in 2006 was a six, which is where it remains today, and Kosovo has stayed at a five (out of 10). ${ }^{84}$ The second BTI indicator helpful in evaluating these end goals is the independence of the judiciary ${ }^{85} \mathrm{In} \mathrm{BiH}$, the independence of its judiciary is deteriorating after more than two decades of transitional trials and international oversight. In 2006, its judiciary was relatively independent, receiving a seven out of 10, but from 2008-2012 it dropped to a six and from 2014-2016 it declined even further to a five, i.e., a judiciary that is heavily impaired by political authority and corruption. Likewise, Kosovo is also weak in this domain, having received a five since 2010.

These results are troubling considering the enormous investment the international community and some local officials have spent on trials over the last two decades. Furthermore, the EU, UN, OSCE, ICTY and other international organizations have spent millions of dollars and countless hours on judicial reform in both states. While there are several factors that contributed to the failure of transitional justice to help improve these areas, the most significant is the prioritization of ethnicity over dealing with the crimes of the past. ${ }^{86}$ In both of these countries, impunity is tolerated as long as the accused or convicted is part of one's ethnic community. For instance, when asked who was responsible for the Bosnian war, Bosniaks and Bosnian Croats identify Serbia (62\% and

\footnotetext{
${ }^{84}$ According to the BTI, a seven is equated to a country where these abuses are generally prosecuted and a four signifies there is not adequate prosecution; hence, both countries fall somewhere in-between.

${ }^{85}$ Within the last chapter, this indicator was used to evaluate whether a predictable and efficient judicial system emerged. But, because it is unlikely there will be a government subordinate to the law without an independent judiciary, this indicator can also be used to measure this end goal as well.

${ }^{86}$ Here, one could also add the failure of international missions to consistently model accountability. But since this analysis focuses on transitional justice, this issue is not discussed.
} 
$61 \%$ respectively), while Bosnian Serbs blame the international community (62\%). (UN Resident Coordinator's Office in Bosnia and Herzegovina, 21) In Kosovo, an overwhelming majority of Kosovo Albanians also believe their ethnic community was not responsible for war crimes (70\%), whereas $49 \%$ of Kosovo's Serbian community also claim innocence. (UNDP 2014, 21)

The war-time narratives that dominate in these countries either portray one ethnic group as entirely the victims or liberators, or claim trials are simply victor's justice. Consequently, in countries where hundreds of thousands of civilians were killed, raped, injured or displaced, there remains vehement disagreements over who is responsible for these crimes. From an outsider's perspective, enough evidence has already been presented in the ICTY, ICJ and other legal forums that demonstrate crimes were committed by all sides, yet the politicization of ethnicity has prevented many from accepting fact. Subsequently, unlike Colombia where there is a relative degree of consensus that all sides share in the blame, in these two Balkan states agreement on a common narrative is not found, and therefore, the investigations and verdicts rendered in war crimes cases are seen by many through an ethnic-colored lens. Evidence of this commitment to ethnicity over justice is found in the lack of cooperation with the ICTY, reactions to local war crimes cases, the failure of society to purge itself and its political leadership of an extreme ethnic ideology and limited regional cooperation on dealing with the past.

In relation to the lack of ICTY compliance and local reactions to war crimes cases, from 1995-96 OHR noted that neither entity was abiding by the Rules of the Road, which meant that both sides were still making arbitrary arrests of war criminals based on 
ethnicity. (October 1, 1996) The bias that had seeped into the local judiciary furthermore forced OHR to begin recruiting international judges and prosecutors. (October 13, 2003) In regards to its international obligations to cooperate with the ICTY, seven years after the termination of hostilities, RS officials had still failed to arrest or even facilitate the arrest of one ICTY-indictee. (May 14, 2002) Furthermore, although the tribunal issued indictments against the two most senior Bosnian Serb leaders in 1995, Ratko Mladic and Radovan Karadzic, the latter would not be apprehended until 2008 and the former not until $2011 .^{87}$

Yet, even after these apprehensions, RS behavior has clearly sought to undermine any foreign trials against Bosnian Serbs. For instance, following Karadzic's apprehension, the RS pledged to support him and his family; by 2016, officials in this entity committed to using public funds to pay the personal expenses of Karadzic, Mladic and two other Bosnian Serbs in The Hague. This pledge consists of a combined monthly stipend of more than 20,000 euros for things such as clothes, telephone bills and food. (Obradovic 2016) Official support has not stopped at monetary contributions. In 2010, the RS Serbian Democratic Party awarded Karadzic its highest honor, and three years later, RS President Dodik testified as a defense witness for Karadzic, stating during his testimony that the defendant, “...never insisted on the commission of any crimes..." 88 (OHR November 8, 2010 and May 8, 2013)

\footnotetext{
${ }^{87}$ Bosniak and Bosnian Croat cooperation with the tribunal was better. (OHR April 9, 1998 and May 14, 2002)

${ }^{88}$ Radovan Karadzic was found guilty and sentenced by the ICTY to 40 years' imprisonment on March 24, 2016. He was found guilty of genocide, crimes against humanity and violations of the laws of war. His verdict is currently under appeal.
} 
Helping to explain this behavior, Subotic argues that war crime trials in $\mathrm{BiH}$ are not about delivering justice; rather, accountability proceedings have been "hijacked" by local elites for political purposes. In the RS, its limited "cooperation" is attributed to pressure from OHR and the EU, as well as its desire to gain legitimacy within the international community. Bosniaks on the other hand have been more supportive because they view it as an opportunity to weaken the RS, and thereby promote greater state unity. $(2009,151-52,159-63)$ While some may argue that motivations for compliance are not as important as convicting the wrongdoers, in this case the elites' behavior, i.e., minimal outward cooperation with the courts while taking action to undermine their results, does not support development of the rule of law. Moreover, recent denials by RS officials that genocide even occurred in Srebrenica despite this having been legally established in the International Court of Justice and ICTY decisions, further erodes confidence that justice is being served, as well as negates any potentially restorative effects from the report issued by the Srebrenica Commission more than a decade ago. ${ }^{89}$ (OHR November 8 , 2010) Unfortunately, this same type of behavior is also found in Kosovo.

Here, compliance by the majority Kosovo Albanian community has on the surface been better. Following the first ICTY indictments against the KLA in 2003, UNMIK reported that the arrests went without incident, although there were approximately twodozen non-violent demonstrations. (UNSYG April 14, 2003, 4) Two years later when the second round of ICTY indictments against the KLA were issued, which involved then Prime Minister Ramush Haradinaj, he immediately resigned, went to The Hague and

${ }^{89}$ See ICTY March 24, 2016 verdict against Randovan Karadizic and ICJ decision of February 26, 2007. 
called upon his fellow Kosovars to respect the rule of law. (UNSYG May 23, 2005, 9) While laudable, the Kosovars' compliance with the ICTY was likely motivated by political interests, namely achieving independence. For instance, in the same report where it discusses the Prime Minister's indictment, the UN requests approval from the Security Council for a comprehensive standards review that summer, which when subsequently completed led to the initiation of status talks. ${ }^{90}$ (Ibid, 6) If the Kosovo government would have ignored the ICTY's indictments, or if the Prime Minister had fled Kosovo, a positive assessment on standards would likely not have been given and a decision on status delayed.

Support for this argument is found in the Kosovo Albanian leadership's behavior behind the scenes. For instance, although Prime Minister Haradinaj went immediately to The Hague, this court's Office of the Prosecutor complained of the difficulty in trying this case because of witness intimidation. (ICTY 2007, 20) Moreover, following the UNMIK arrest of several former KLA members for war crimes in 2002, Kosovo's provisional government issued a resolution condemning the arrest of KLA "political prisoners." (UNSYG October 9, 2002, 5) Furthermore, the UN believes that a March 2004 protest against the arrest of four former KLA was part of the spark that ignited several days of ethnic riots later that same month. These riots, which were led by Kosovo Albanians and largely targeted minority communities, resulted in 19 deaths, 954 injuries and the damage or destruction of 730 homes and 36 Serbian Orthodox sites. (UNSYG April 30, 2004, 1-2) While several Kosovo officials initially blamed the riots on Serbia

\footnotetext{
${ }^{90}$ During its mandate, UNMIK outlined a handful of Standards for Kosovo, which included good governance, the rule of law and protection of ethnic rights as benchmarks that would be periodically measured to assess Kosovo's readiness for a status outcome.
} 
and UNMIK's presence in the province, the true tell of the tolerance for impunity is the lack of prosecutions that followed. Four years after these deadly events, the OSCE assessed the judicial response to these ethnically-based crimes as poor. Overall, witnesses did not come forward, sentences were too lenient, ethnicity was not considered a motivating factor in the trials and many local police who were summoned as witnesses refused to testify. (OSCE 2008, 3, 21) Moreover, of the more than 50,000 people estimated to have participated in the riots and from the 1,400 criminal complaints filed, only 301 people were convicted of riot-related crimes. (Ibid, 3)

Although the aforementioned incidents are from more than a decade ago, many Kosovo Albanians remain unwilling to acknowledge atrocities its forces committed during the war. During one war crimes trial in 2010, then Prime Minister Hashim Thaci referred to one defendant, who was also a member of his government, as a freedom fighter and innocent of the accused crimes. (EULEX 2010, 31) In April 2011, a mayor was sentenced to 30 days in jail for refusing to testify in a war crimes case. (UNSYG May 3, 2011, 7) Most recently, the continuation of impunity precipitated the international community to establish the Specialist Chambers outside of Kosovo. Describing why this court was needed in The Hague, Kosovo Prime Minister Mustafa told his parliament, "Unfortunately, the failure of the rule of law, in many cases, has influenced the international community's loss of trust that we can develop this process in our country." (Collak 2015)

In addition to the overt and more subtle obfuscation of ICTY and local war crime proceedings, there has been a general lack of political lustration and societal rejection of the war-time parties and the goals they espouse. Under UNMIK, EULEX and OHR, 
vetting of judges and prosecutors was done. But, in general, there has not been any comprehensive lustration of the parties and officials responsible for waging these wars. Subsequently, many of those involved in the war remain politically active, and as one Bosnian official observed, while the physical violence stopped, the war has never ended..$^{91}$

For example, in Kosovo, three of its post-war prime ministers were senior KLA commanders, one of which was tried in the ICTY for war crimes. ${ }^{92}$ Additionally, two of the three largest political parties in Kosovo, the Democratic Party of Kosovo and Alliance for the Future of Kosovo, formed as a result of the demobilization of the KLA, and still embody many of this entity's aspirations. Kosovo has also elected an indicted war criminal to its Assembly (Fatmir Limaj). In BiH, current members of the government were also in positions of authority before the war, such as RS President Dodik. Equally troubling and possibly more corrosive to the rule of law has been the persistence of war criminals within the ranks of the RS police. In 1997, OHR warned of the existence of war crime indictees in the local police, and ten years later the High Representative still had to take executive action, seizing the passports and suspending 35 police officers in the RS because they were under investigations for war crimes. (OHR July 11, 1997 and November 15, 2007) According to Subotic, an estimated 1,000 alleged perpetrators of crimes in Srebrenica were still in the RS police force. $(2009,157)$

Certainly, it is reasonable that war-time leaders will seek to retain positions of power once the conflict ends, and it is acceptable that those war-time leaders or soldiers

\footnotetext{
${ }^{91}$ Interview, supra n 78.

92 These are Ramush Haradinaj, Agim Ceku and Hashim Thaci.
} 
not responsible for war crimes be able to serve their country once they have laid-down their arms. As was illustrated in Chapter Three, several former guerillas in Colombia have made the successful transition to politics, and have become respected members of the government after completing officially-sanctioned amnesty processes. What differs in $\mathrm{BiH}$ and Kosovo, where there has been no amnesty and accountability has been prioritized, is that when there is a public policy of accountability yet individuals with criminal and questionable pasts are allowed to remain in positions of power, a doublestandard emerges and impunity is allowed to fester. Additionally, allowing these politicians and police to remain in office also makes it easier for them to manipulate the justice system.

One common theme that emerged in the one-on-one interviews, and which is borne-out by the BTI, is that the courts in both $\mathrm{BiH}$ and Kosovo are heavily influenced by political forces. One international official in Sarajevo noted that judicial decisions are often based on politics and not the law. ${ }^{93}$ And since politics are driven by ethnicity in these two countries, ethnicity can dictate court decisions. The OSCE noted in a recent report that at the state level in $\mathrm{BiH}$, the WCC and State Prosecutor's Office are constantly being attacked politically in order to influence war crimes cases; consequently, the barrage of attacks is eroding public trust in these trials. $(2011,85-86)$ This same level of political interference has also been noted by the UN in Kosovo. In his July 2010 report, the UN SYG warned of political interference in the judiciary at all levels, and three years later, the UN noted that during the war crimes trial of a Kosovo Assembly member,

${ }^{93}$ International official, interview, June 7, 2016, Sarajevo, BiH. 
Kosovo Albanian officials attempted to intervene in the proceedings. (UNSYG February

4, 2013, 15) Judicial interference has risen to such a level in Kosovo that the OSCE warns that this behavior is negatively impacting the rule of law. $(2012,4)$

While it is clear that lustration did not go far enough, one must accept that many of these government officials have been democratically elected, often in elections monitored by the international community. President Dodik, Ramush Haradinaj and others were all chosen by their people. Moreover, while the international missions in both states had the authority to sanction and remove politicians, it was not easy to do. Both OHR and UNMIK were sent to establish and strengthen indigenous institutions of local government. Those locals capable of governing and capable of soliciting enough public and political support to win elections were also likely involved in war-time politics. In order to effect change, the international community was sometimes required to work with officials it probably preferred not to engage. Yet, while some responsibility falls at the feet of the international missions for not encouraging a wider lustration policy, in the end, the people of $\mathrm{BiH}$ and Kosovo are ultimately responsible for who they elect.

One well-known scholar of Southeastern European politics contends that one of the missing pillars in transitional justice is the failure of society to come to terms with its responsibilities for the atrocities that were committed. The emphasis that trials place on individual accountability allows societies to ignore their direct or indirect complicity in the crimes that occurred. (Subotic 2011, 158-59) Describing society's role, she reminds readers, "They [the war-time governments] built their policies on a societal receptivity to violent claims that were broadly accepted, normalized, and routinized in society and gave criminal policies a patina of legitimacy." (Ibid, 160) Therefore, what should accompany 
trials are things that require larger societal participation, such as apologies, reparations, public commemorations and truth commissions. (Ibid, 159-61) Unfortunately, there has not been a balanced approach to transitional justice in either Balkan state, and the various ethnic communities continue to resist accepting culpability for the crimes that transpired. This obstinacy to deal truthfully with the past is also clearly found in the lack of regional cooperation in prosecuting war crimes, working together to identify the missing, establishing a record of truth or providing reparations. While the Kosovo and Bosnian governments clearly have responsibilities to lead their transitional processes, the conflicts in both $\mathrm{BiH}$ and Kosovo involved other countries as well, particularly Serbia. The ethnic tensions that persist between these states continues to feed ethnic extremists while inhibiting the development of comprehensive transitional justice strategies. For instance, while Kosovo's Albanian-led government has certain responsibilities for executing transitional justice, any program will be incomplete without Serbia's involvement and resources. Serbia was the other actor in this bloody history, yet because Serbia has not had to govern Kosovo since 1999, it does not have any internal pressure or desire to make amends.

When asked about the state of regional cooperation, an ICTY official replied that it is still insufficient, and that the realities of dual-citizenship and unwillingness of these countries to extradite war criminals provides sanctuary for many perpetrators. Absent an agreement on extradition, most of the countries in the region now rely upon agreements 
that require convicted war criminals to serve their time in the country where they reside. But, even here, the ICTY acknowledged that these requests are sometimes ignored. ${ }^{94}$

Outside of trials, cooperation on other mechanisms is equally poor and driven by ethnic animosities. Reference has already been made to the unwillingness of any country to participate in a regional truth commission over fears of equating levels of victimization and lack of trust. In Kosovo, one civil society activist lamented the failure of Kosovars to file reparation claims in Serbian courts before independence, and she believes at the very least, Serbia should offer an apology for the crimes its forces committed in Kosovo. ${ }^{95}$ The head of Kosovo's Commission on Missing Persons agreed that at a minimum an apology should be offered, but he explained that Serbia also needs to be more forthcoming in providing information on the whereabouts of the remaining 1,665 missing from Kosovo. Mr. Gjetaj noted that Serbia's actions in Kosovo during the war were coordinated, and when they withdrew, he believes these forces took the dead bodies with them and reburied or incinerated many of them in Serbia. Without resolution of the missing, reconciliation will be harder and accountability incomplete. ${ }^{96}$

The lack of regional cooperation, the failure of these societies to truly purge themselves of a toxic ethnic ideology and those politicians that support it, as well as efforts to undermine war crimes trials all point to how ethnicity is being prioritized over justice. This ethnic inhibiter has prevented the multiple levels of trials from developing

\footnotetext{
${ }^{94}$ ICTY official, interview, June 3, 2016, Sarajevo, BiH.

${ }^{95}$ Nora Ahmetaj, Consultant on Transitional Justice, Centre for Research, Documentation and Publication, interview, June 13, 2016, Pristina, Kosovo.

${ }^{96}$ Prenk Gjetaj, Government of Kosovo Commission on Missing Persons, interview, June 17, 2016, Pristina, Kosovo.
} 
within these countries the accountability of all before the law. However, the hope is that over time, the reification of ethnicity will be weakened as these countries move closer to the EU, and with a new vision for the future, these trials will be viewed more positively.

\section{Law \& Order}

Another aim of transitional justice, particularly trials, is to deter future bad behavior. (Sikkink 2011, 169-71) Subsequently, much like the last two end goals, the extensive use of trials should have led to a significant reduction in the number of serious crimes, especially those targeting ethnic communities. While there has fortunately been a reduction in the numbers of murders and assaults in both countries since the termination of their conflicts, the reductions were not immediate, and it is not clear that trials were the cause. In addition to examining rates of serious crimes, adherence to law and order should also be manifested in the protection of property rights. Both countries emphasized policies to restore property to the displaced, but like much of what has already been discussed, the promotion of property rights has also been inhibited by ethnic tensions as well as a lack of resources.

In their immediate post-conflict environments, ethnic attacks continued in both $\mathrm{BiH}$ and Kosovo despite the ongoing operations of the ICTY. In both states, violent retributive actions against other ethnicities were commonplace; for three years (1996-98), OHR reported regular police beatings and torture of prisoners in both entities, along with an increase in attacks against religious heritage and the vacant properties of the displaced.

(October 1, 1996, October 16, 1997, and July 14, 1998) In Kosovo, the situation was equally appalling. The UN reports from 1999-2001 highlight regular episodes of lawlessness, retribution and the absence of law and order. The killings of Kosovo Serbs, 
looting their homes and setting ablaze Serbian patrimony was all too common in 1999. (UNSYG July 12, 1999, 2) Fortunately, with the deployment of international and local police, by 2002 serious crimes against minorities had decreased from "systematic to random," but in March 2004, ethnic animosities boiled-over once again. (UNSYG January $15,2002,6)$

Although there has not been a major outbreak of ethnic violence in either Kosovo or Bosnia since 2004, ethnic relations are contentious. For instance, in its 2011 and 2012 reports, the UN noted that ethnic crimes had increased in Kosovo 24\% during the summer-fall period of 2011 when compared to the same time in 2010. (UNSYG October 31, 2011, 5) Moreover, in 2012, ethnic crimes continued to rise. (April 27, 2012, 5) In $\mathrm{BiH}$, many are still concerned that there will be another Mladic, and RS threats to hold a referendum next year on independence only exacerbates existing ethnic tensions. (OHR October 21, 2016)

The persistence of ethnic animosities also appears to be reflected in crime statistics for both countries. ${ }^{97}$ For instance, the number of assaults recorded by the police in $\mathrm{BiH}$ was more than 1,300 in 2005 ; this figure rose to close to 1,600 in 2007 , but by 2010 it had fallen to 505. In Kosovo, more than 3,300 assaults were committed in 2008, and the number did not drop below 3,000 per-year until 2013 when there were only 653 . (United Nations Office on Drugs and Crime) Figures on the number of murders per 100,000 people also reflects a stubbornly slow decline in serious crimes. For example,

\footnotetext{
${ }^{97}$ Local crime statistics for both $\mathrm{BiH}$ and Kosovo are difficult to find. Neither UNMIK nor OHR provide regular crime statistics, and the national statistical agency for BiH did not begin producing public reports until 2011. Kosovo's statistics agency did not publish its reports until 2005, and its section on crime only counts the number of cases before local courts. Moreover, UNODC's statistics on murders and assaults only begins in 2005 .
} 
according to UNODC, there were approximately 1,900 murders throughout Kosovo in 2008; by 2011 the number had declined to only slightly more than 1,000. Table 4.1 provides statistics on the murder rates in both countries.

Table 4.1: Murder Rates in BiH and Kosovo (per 100,000 people)

\begin{tabular}{|c|c|c|}
\hline Year & BiH & Kosovo \\
\hline 2009 & 71 & 73 \\
\hline 2010 & 56 & 106 \\
\hline 2011 & 51 & 62 \\
\hline 2012 & 63 & 90 \\
\hline 2013 & 46 & 41 \\
\hline 2014 & 50 & 41 \\
\hline
\end{tabular}

*Data is from UNODC.

Since the available data does not provide a breakdown of victims by ethnicity, and because there are no reliable statistics on the numbers of assaults and murders in the immediate post-conflict years, reaching any definitive conclusions regarding the impact of transitional justice on improving law and order viz-a-viz reductions in serious crimes is difficult to achieve. It is possible that it took many years for the deterrent effect to be realized, or it could be that there have been fewer murders and assaults in $\mathrm{BiH}$ due to the federated structure, i.e., the ethnic divide is more tangible and therefore there is less interaction between the ethnic communities. What can be ascertained, however, is that the cessation of the wars and the deployment of international peacekeepers and police stopped any further episodes of genocide and widespread ethnic cleansing.

After the Dayton Accords, NATO deployed 60,000 troops to BiH under the Implementation Force (IFOR), followed by a smaller $(32,000)$ Stabilization Force (SFOR) from 1997 through 2004. From 2005 to today, the EU has military forces there under Operation Althea, which initially numbered 7,000 troops. For Kosovo, the international community provided a NATO-led Kosovo Force (KFOR) of close to 50,000 
troops in 1999; KFOR remains on the ground, today numbering around 4,500 international military personnel. (NATO) In addition to these forces, the UN deployed a 4,500 civilian-member police mission to help UNMIK restore law and order, which was followed by approximately 1,000 European and U.S. police under EULEX command in 2008. (UNSYG December 15, 2000, 5, UNSYG March 17, 2009, 4) Subsequently, some of the stability and reduction in violence can be attributed to these robust international security deployments. In addition to the international community providing security, these countries' international governing missions also played a role in promoting property rights, albeit with mixed results.

Similar to events in Colombia, during the conflicts in $\mathrm{BiH}$ and Kosovo, property rights were not respected. Bosnia's Commission on Real Property Claims for Displaced Persons and Refugees (CRPC) received at least 148,167 claims; in Kosovo, its Housing and Property Directorate (HPD) was required to resolve 42,701 residential property disputes. (OHR February 12, 1999, UNSYG August 1, 2014, 13) How these internationally-led agencies, along with their local implementing partners handled this aspect of restorative justice is a useful yardstick in measuring the state of a country's law and order. Unfortunately, these transitional mechanisms were only effective in adjudicating claims; the lack of political will to enforce these decisions has hindered these processes successful completion.

According to the Heritage Foundation Index of Economic Freedoms, which forms part of the WGI's rule of law score, property rights in $\mathrm{BiH}$ are abysmal. On a scale from 0 (minimum protection) to 100 (optimal property rights), $\mathrm{BiH}$ languished at a 10 from 1998-2009; from 2010-2015, these rights improved slightly to 20. Data for Kosovo is 
only available for 2012, which despite 12 years of HPD-led work, only produced a 30 out of 100. Although both the CRPC and HPD completed the resolution of claims in 2006 and 2015 respectively, implementation of their decisions has been slow. From the more than 19,000 claims adjudicated by HPD as of November 2004, only $46 \%$ of these decisions had been implemented. (UNSYG November 17, 2004, 17) In BiH, six years into its work, only $29 \%$ and $13 \%$ of the CRPC's decisions were implemented in the Federation and RS respectively. (OHR March 12, 2001) Assessing why there has been poor rates of compliance, both OHR and UNMIK cite a lack of political will, particularly at the local/municipal level. Processing thousands of property claims is not easy, particularly in countries where property records might be non-existent or reside in other countries (Serbia). Yet, in these situations, the sheer logistical difficulty was compounded by local resistance or ambivalence to the importance of these rights. In these two countries where hundreds of thousands were displaced, enforcing property rights is not simply about following a judicial decision; ensuring property rights is central to other issues, such as the return of the displaced.

Despite the work that has been done, largely by the international community, Kosovo Albanians continue to loot and vandalize Kosovo Serb homes and cultural patrimony, and the European Commission notes that although the CRPC was terminated in 2009, there remains a lack of political will and resources to finish the remaining cases/appeals, develop a database for unresolved property claims and provide reliable registries. (UNSYG October 31, 2011, 5, EC 2010, 19) Unfortunately, within this rule of law end goal, the impact of transitional justice is minimal. The cessation of the conflicts and deployments of international peacekeepers and police appear to have played greater 
roles in restoring law and order than any potential deterrent effect. Moreover, despite the adjudication of thousands of property claims, which helped slightly improve property rights, the implementation of these decisions was delayed or ignored due to a lack of political will based on lingering ethnic divisions.

\section{Predictable \& Efficient Justice}

Unlike the inefficiency that plagues Colombia's Justice and Peace process, transitional trials in both $\mathrm{BiH}$ and Kosovo are now operating more regularly and efficiently following their own slow starts. Unfortunately, this improved performance in domestic and hybrid war crimes trials has not been transferred into the overall judicial systems. In light of the fact that the international community controlled the initial wave of trials, primarily through the ICTY, as well as OHR's, UNMIK's and EULEX's executive management of the justice systems, the responsibility for the failure to inculcate these qualities more widely rests as much with the international community as with Bosnian and Kosovar authorities. While missteps by the international community are part of the explanation for the lack of diffusion from transitional trials, other postconflict inhibiters are also preventing these systems of justice from fully maturing. In order to assess the predictability and efficiency of the rule of law, the manner in which the ICTY, hybrid and domestic war crimes trials operated, as well as the overall efficiency of the justice system, is examined.

In terms of the ICTY's ability to operate efficiently, the court's record is disappointing. Since its mandate began in 1993, the ICTY has only sentenced $52 \%$ of the 161 individuals it indicted. Twenty indictments were withdrawn, 17 indictees died before a final verdict, 19 were acquitted, 13 cases were sent to local courts and two are currently 
being retried. (ICTY website) While the number of convictions is not a court's full measure of success, the rate at which the Tribunal processed these cases does reflect a court that was not too concerned with efficiency. For instance, the average proceedings ranged anywhere from three to eight years, and in some cases, i.e., Slobodan Milosevic, trials ended without a verdict due to the death of the defendant. Moreover, it took the court 12 years to issue all of its indictments, and although not entirely its fault, the tribunal is still adjudicating cases almost 25 years after its establishment. While the ICTY cited the lack of funding and intermittent international attention as reasons for the slow pace of its work, the tribunal enjoyed an annual budget of $\$ 200-\$ 300$ million for many years, and at its zenith it had more than 1,000 staff, investigators, prosecutors and judges. (ICTY 2005 and 2007, 10, 23) Why the ICTY was not able to indict and sentence more than 161 individuals over two decades is beyond the scope of this analysis, but this output does raise questions about the efficiency of this court.

Locally, the hybrid and domestic courts in $\mathrm{BiH}$ and Kosovo were also initially inefficient, but in recent years, the rate and quality of the verdicts have improved, especially in $\mathrm{BiH}$ with increased donor aid and growing local capacity. For example, from 2005 through 2012, Bosnia's WCC closed on average 12 cases/year; from 20132015, this rate jumped to 23 cases/year. This increased efficiency is also found in the entities; in the Federation for instance, it closed five more cases a year over the 20132015 period compared to 2004-2012. (OSCE 2015, 1) Overall, Bosnia's courts have completed 361 war crime cases between 2004-2015, including 537 defendants, and an 
additional 260 cases were pending or already in the trial phase. ${ }^{98}$ (Ibid) In terms of the length of time it takes to finish a case, the less complex cases are usually done in less than a year and the more complex in $1 \frac{1}{2} 2$ to 2 years. (OSCE 2011, 56)

In Kosovo, UNMIK failed to prioritize war crimes cases during its executive mandate, and by 2009 only 37 war crimes cases had been tried. (OSCE 2010, 8) When it transferred responsibility for war crimes to EULEX, UNMIK gave the EU 1,187 war crimes reports and 50 cases for trial. (UNSYG March 17, 2009, 13) Of the approximately 1,200 cases, EULEX dismissed 500 for lack of evidence, and by June of 2013, EULEX and local judges had issued a verdict or were in the process of hearing 20 cases. (EULEX 2013) Despite this modest improvement in Kosovo, the average length of a war crimes case is still painfully slow, ranging from five to eleven years. (OSCE 2010, 20) How many cases remain in both $\mathrm{BiH}$ and Kosovo is unclear, particularly since both EULEX and Bosnian prosecutors continue to issue new indictments. What is clear, however, is that $\mathrm{BiH}$ missed its initial goal of completing all of the most complex war crimes cases by 2015, and the international bodies following these trials are doubtful that even with more efficient procedures these countries can complete all of the remaining cases before interest and resources are depleted. (Ibid, 21, EC 2016, 27)

Putting aside the rate of processing war crimes cases, transitional justice also posits that capacity-building will take place locally when international and hybrid courts work closely alongside their domestic counterparts. It is theorized that as international judges develop case law or work alongside local judges and prosecutors, local capacity

\footnotetext{
${ }^{98}$ The WCC processed 142 of these cases, the Federation 120, the RS 86 and Brcko 13.
} 
will grow. (Stromseth, Wippman and Brooks 2006, Chapter 7) Yet, according to Stromseth, there can also be a "spaceship effect" if international judicial personnel simply deliver justice but do not leave a lasting imprint. (Stromseth 2011, 172-73) Unfortunately, in Kosovo, the spaceship effect is apparent, although the ICTY and OHR did a better job of building local capacity in $\mathrm{BiH}$.

For instance, in BiH, the ICTY has an established track-record of active engagement. The ICTY helped establish the WCC, it monitored local courts through the Rules of the Road, it transferred 10 cases to the WCC and through Bosnia's law on the transfer of cases it shares evidence and testimony with local courts. Moreover, from 1999-2006, the ICTY's office of Outreach Activities, which coordinated things like regional training, provided 107 events for BiH but only 19 for Kosovo. (ICTY Outreach Activities Archives) Consequently, in 2016, the ICTY assessed local prosecutors' capacity in war crimes to be generally good and even throughout $\mathrm{BiH}$, which includes a cadre of 36 state war crimes prosecutors. ${ }^{99}$ Although there were fewer war crimes in Kosovo, the fact that EULEX still leads most investigations and tries most cases, and that there was only one Kosovo war crimes prosecutor as of June 2016, it is fair to conclude that the ICTY, UNMIK and EULEX have generally failed to build the same level of capacity in Kosovo than the ICTY and OHR did in BiH. In fact, representatives of both the Kosovo Judicial Institute and Kosovo's State Prosecutor's Office acknowledged their country still lacks training in international humanitarian law, and they both welcomed more capacity-building efforts by the international community. ${ }^{100}$

\footnotetext{
${ }^{99}$ Interview, supra n 94.
} 
Although $\mathrm{BiH}$ is showing progress in local war crimes capacity, the overall state of both countries' judiciaries viz-a-viz efficiency and predictability is anemic. In both the civil and criminal courts, hundreds of thousands of cases are languishing, and the backlog is growing. In 2007, the European Commission found two million unresolved cases in BiH, and by 2016, there were a little more than two million. ${ }^{101}$ (EC 2007, 13 and EC 2016, 14) In Kosovo, there were 280,638 un-adjudicated cases in 2008, which by 2016 had grown to approximately 400,000. ${ }^{102}$ (EULEX 2009, 99) Because of these delays, the Kosovo Ombudsperson warned in his $11^{\text {th }}$ report that the biggest complaints his office received regarding the judiciary were the delays in cases and non-enforcement of decisions, which is leading to growing public distrust in the courts. (UNSYG November $8,2012,9)$ In light of these and other problems, which are beyond the scope of this analysis, Bosnia's judiciary was recently assessed to have "some level of preparation" for EU membership, whereas in 2012, the EU graded Kosovo's judiciary as a B, which signified "slow progress/need more impetus." (EC 2015, 12, EULEX 2012, 8)

While these international reports provide one perspective, the inefficiencies of the judicial systems are often a frequent complaint of the people they are created to serve. According to polling data, $48 \%$ of respondents in Kosovo in 2008 stated they had confidence in the judiciary, yet, by 2012 this level dropped to 35\%. (Gallup Balkan Monitor) When asked in 2010 if they were satisfied with their courts and prosecutors, the

\footnotetext{
${ }^{100}$ Valon Jupa, Head of Continuous Training Programs, Kosovo Judicial Institute, interview, June 14, 2016, Pristina Kosovo.

Kujtim Munishi, Kosovo State Prosecutor's Office, interview, June 20, 2016, Pristina, Kosovo.

${ }^{101}$ Out of these two million cases, approximately 1.2 to 1.7 million are unpaid utility bills.

${ }^{102}$ Interview, supra n 100 (Kosovo State Prosecutor's Office).
} 
response was even worse. Only $19 \%$ of Kosovars were satisfied with their courts and only $15 \%$ with their prosecutors. By 2015 , these totals dropped to $14 \%$ and $13 \%$ respectively. (UNDP Public Pulse Report 1, UNDP Public Pulse Report 12) In BiH, the majority of respondents also lack confidence in their judiciary (59\%) whereas only $34 \%$ did. (Gallup Balkan Monitor) While these polls reflect public attitudes and not actual performance, it is reasonable that public attitudes are shaped in part by the courts' performances. If these judiciaries were operating efficiently, it is likely that these ratings would be higher. Explanations for why international efforts and recent local ownership have failed to improve the judiciary are captured by three post-conflict realities.

First, it should be acknowledged that the state of the judiciaries in both countries following their conflicts was poor or non-existent. Conflict destroyed the physical infrastructure, and many judges and prosecutors were killed or fled as a result of the violence. OHR's reports noted that this international mission was focused on institutionbuilding within the judiciary from 1996-2005; in early 2006, OHR finally reported that BiH now had the laws and institutions to "...inculcate and maintain the rule of law." (January 31, 2006) Kosovo's judiciary, which relied upon an emergency, ad-hoc judicial system for much of its first year, is still growing, although by 2003 it was handling 90\% of the criminal and civil cases, and in 2005 ministries of interior and justice were established. (UNSYG January 29, 2003, 8) The fact that both the international community and local officials had to reassemble or assemble a judicial system needs to be taken into account when evaluating the progress in building predictable and efficient institutions. 
Yet, even with significant international oversight and assistance, the lack of physical and financial resources has stymied efforts to build a more complete judiciary. In 2008, the European Commission noted that the material conditions of Bosnia's judiciary were sub-par, and in 2014, $13 \%$ of judgeships in this country still remained vacant due to a lack of funding. (EC 2008, 13, EC 2014, 12) Subsequently, the EU recently provided 15 million euros to help fund the salaries of local prosecutors and judges. ${ }^{103}$ Kosovo too suffers from a lack of personnel caused by a dearth of resources. For instance, EULEX reported in 2009 that the number of judges and prosecutors in this Balkan state were well below regional averages; in 2009, there were only 14 Kosovo judges per 100,000 inhabitants. In BiH, it had 22 judges per 100,000 residents in 2009. As for prosecutors, Kosovo's four per 100,000 was well below the 13 in Montenegro and seven in BiH. (88) Little had improved by 2011 when 127 judgeships remained vacant, and in 2016, representatives in the Kosovo Prosecutor's Office and other judicial bodies highlighted a lack of personnel due to a shortage of government funding. ${ }^{104}$ (EULEX 2011, 36)

Although a lack of infrastructure and resources can be expected in post-conflict states, the international community has also made some mistakes that have exasperated inefficiencies. In BiH's complicated federated structure there are 15 different police forces, 14 different ministries of justice, 14 different judicial budgets and four different criminal codes. When it comes to transitional justice, particularly trials at the entity level,

\footnotetext{
${ }^{103}$ Niko Grubešić, Assistant Minister and Head of the Sector for Strategic Planning, Aid Coordination and European Integrations in the BiH Ministry of Justice, interview, June 6, 2016, Sarajevo, BiH.

${ }^{104}$ Interviews, supra n 100.
} 
the disparity in funding has led to differing levels in the quality of justice. (EC 2005, 17) Moreover, for many years, the WCC used the 2003 state criminal codes retroactively, whereas the entities applied the criminal codes from the SFRY. Subsequently, individuals convicted of the same crimes could have received different sentences. For instance, the SFRY codes did not permit prison terms beyond 20 years, whereas under Bosnia's 2003 criminal codes, an individual could be sentenced to 45 years in prison. (OSCE 2011, 48, 70-71) In light of these challenges, the OSCE contends that the biggest obstacle to addressing war crimes in $\mathrm{BiH}$ is the harmonization of judicial efforts. (Ibid, 94) While it is hard to second guess decisions made in the context of the Dayton Accords, the system that is in place is not conducive to establishing a solidified judicial structure. The fact that the entities could apply different criminal codes and that there is no state court of last instance allows justice throughout $\mathrm{BiH}$ to be uneven. ${ }^{105}$ Unfortunately, until the ethnic tensions preventing a more unified state are resolved, there does not appear to be an easy or quick fix to these problems.

While Kosovo was spared the bifurcated federated structure found in $\mathrm{BiH}$, the unsettled state of Kosovo's judiciary has impeded judicial consolidation. Since 1999, Kosovo's courts and laws have been subject to a never-ending cycle of change. From 1999-2004, FRY and Serbian laws, along with UNMIK regulations, served as the foundation of the criminal justice system. In April of 2004, new criminal codes and procedures, which were more consistent with an adversarial system, were implemented; six years later, this time under EULEX, new criminal codes and procedures were

\footnotetext{
${ }^{105}$ A representative at the BiH Ministry of Justice informed me that efforts are being made to consolidate the four different criminal codes.
} 
developed, which came into effect in 2013. Assessing this flux, the OSCE notes that it has been hard for the rule of law to take hold since Kosovo's judiciary has been in a state of transition for more than a decade. $(2012,6)$ To compound these problems, war crimes cases have sometimes been forced to start over after new judges or prosecutors rotate into Kosovo. The terms of these international judges and prosecutors are not fixed, and with cases taking anywhere from five to eleven years, a judge that began hearing a case is likely not the same judge to render a verdict. (OSCE 2010, 15-20) In light of these factors, along with an inconsistent capacity-building program, war crime trials have had a hard time helping build institutions that are predictable and efficient. And, as will be discussed in the fifth and final end goal, transitional trials have also been limited in developing human rights, especially in light of lingering ethnic animosities.

\section{Upholding Human Rights}

In order to assess whether transitional justice improved human rights, it is useful to evaluate whether trials helped deter political violence and protect civil liberties. According to the Political Terror Scale (PTS), after receiving the worst score (5) during its four years of conflict, politically-orchestrated violence in $\mathrm{BiH}$ fell to a three from 1996-2000, a two from 2001-14, and most recently a one. ${ }^{106}$ Since the PTS did not begin to measure political violence in Kosovo until 2008, trends in this country are hard to discern, although this scale has assigned either a one or two to this Balkan nation since its first measurement. (Gibney et al. 2016) Another WGI-related metric, Freedom House's annual scores of civil liberties, which are found in Table 4.2, mirrors the PTS. During the

\footnotetext{
106 According to the PTS, a five represents a country where political terror is prevalent throughout the entire population; four notes that political violence is common; three signifies that violence may be common; two, violence is exceptional and one violence is rare.
} 
first several post-conflict years, the protection of civil liberties in $\mathrm{BiH}$ and Kosovo was poor; following these early years, civil liberties have consistently improved, although they are still not optimal.

Table 4.2: Protection of Civil Liberties in BiH and Kosovo (1996-2015)

\begin{tabular}{|c|c|c|}
\hline Year & $\mathrm{BiH}$ & Kosovo \\
\hline 1996 & 5 & 7 \\
\hline 1998 & 5 & 6 \\
\hline 2002 & 4 & 5 \\
\hline 2005 & 3 & 5 \\
\hline 2008 & 3 & 5 \\
\hline 2010 & 3 & 4 \\
\hline 2015 & 3 & 4 \\
\hline
\end{tabular}

*Data is from Freedom House. Its scale ranges from 1 (optimal protection of civil liberties) to a 7 (poor protection of civil liberties).

While transitional trials may have helped reduce political violence and promote civil liberties through a deterrent and/or demonstration effect, there were other, potentially more powerful factors, that likely contributed to these changes. For instance, international governing missions with executive authorities, including thousands of international police in Kosovo, have helped to temper the political environment, and when necessary, use their executive authorities to pass laws that protect human rights and civil liberties. Furthermore, there have also been strong political forces at work encouraging civility and human rights. In Kosovo, the international community would have been hard pressed to issue a positive assessment on standards or recognize a declaration of independence if there were widespread violations of human rights. Moreover, While Bosnia did not have to adjust its behavior for independence, OHR's executive authorities and Bosnia's pursuit of EU membership established human rights as a governing priority. 
Other examples that show that transitional justice did not usher-in meaningful human rights reforms are manifested in the previously cited local reactions to war crimes cases, along with the failure to take care of the victims. As was already outlined, while $\mathrm{BiH}$ and Kosovo officials improved cooperation with the ICTY, at least on the surface, their efforts to undercut war crimes cases and their verdicts indicates that ethnicity trumps prosecuting those who violated human rights. For instance, the RS pledging its financial support to indicted and convicted Bosnian Serbs responsible for genocide while failing to provide their victims monetary compensation sends a clear signal that human rights are not being prioritized. Furthermore, RS officials' denials that genocide even occurred in Srebrenica, including statements by RS President Dodik, clearly indicate a true embrace of human rights has not yet occurred. (OHR November 8, 2012) Furthermore, Kosovo officials proclaiming that indicted war criminals are heroes and innocent before verdicts are even rendered also undercuts the potentially powerful message of human rights trials.

In addition to this destructive behavior, the failure of $\mathrm{BiH}$ and Kosovo to develop and execute comprehensive transitional justice strategies leaves many victims still struggling to recover from wars that occurred more than two decades ago. While resources are limited, public officials and members of civil society noted that the lack of political will, not insufficient funding, was the primary reason transitional strategies are still not in place. ${ }^{107}$ Although victims welcomed trials, they and their representatives

\footnotetext{
${ }^{107}$ Interviews, supra n. 78. Interview, supra n. 95.
} 
clearly want state recognition of their suffering through things such as psychosocial assistance and reparations for homes they are unable to return to due to ethnic tensions. ${ }^{108}$ Conclusion

The cases of $\mathrm{BiH}$ and Kosovo should be theory affirming viz-a-viz the relationship between transitional justice, particularly trials, and improving the rule of law. Both countries utilized a wide variety of transitional trials, yet as was shown, these trials had minimal, positive effects in most of the five end goals of rule of law reform. In fact, in areas where the effects of trials should be most apparent, i.e., establishing the equality of all before the law and helping create efficient judicial institutions, $\mathrm{BiH}$ is declining and Kosovo remains relatively weak. Overall, in both countries, impunity for war crimes is tolerated and even sometimes celebrated as long as the perpetrators are part of one's ethnic community.

According to the literature, part of the explanation for this regression and stagnation should be attributed to the international models that were imposed upon both countries. Citizens in both Balkan states did not participate in the development and execution of their respective international models, and therefore, transitional justice should not play a major role in the development of the rule of law. While the improvements in the mean rule of law scores coincide with these countries changes to mixed models, the evidence clearly shows that problems such as impunity and inefficient judicial systems have existed under both forms of transitional justice. Moreover, under a mixed model, the independence of Bosnia's courts is deteriorating, and since 2014, this

\footnotetext{
${ }^{108}$ Interview, supra n 69. Interview, supra n 83.
} 
country's mean rule of law has been declining. Furthermore, the minor improvements in property rights were not as a result of the shift in models; the international community imposed this form of reparations, and it generally managed these processes. When it came time to implement these decisions, local opposition hindered its successful completion.

Furthermore, there is currently not enough data to argue that hybrid and domestic trials served as a deterrent effect, leading to the improvements in law and order and less political violence. These changes could be the result of the deployment of international security forces, the development of more professional police, the solidification of ethnic divisions or the political pressure surrounding these countries' desires for independence and EU membership. The fact that the political leadership and many others continue to promote a dangerous ethnic ideology illustrates that a true change has yet to occur. Consequently, in these two countries, the effects of transitional justice on the development of the rule of law have been minimal at best. This, however, does not mean that in the future the array of trials and convictions will not help future generations deal with this ugly period, but at the present, the prioritization of ethnicity over dealing with the past inhibits transitional justice from playing a more meaningful role.

In addition to ethnicity, two other inhibiters prevented more meaningful change. In line with Olsen, et al.'s justice balance for human rights and democracy, it appears trials also need to be accompanied by restorative mechanisms to help promote the rule of law. As was illustrated in a Bosnian poll, only $4 \%$ of respondents had any interaction with the ICTY or local war crimes trials. (UN Resident Coordinator's Office in Bosnia and Herzegovina, 29) Although property was returned to some, many victims are still not 
able to go home due to lingering ethnic animosities, and the state, including Serbia, has never apologized or attempted to financially restore the victims to their pre-war state.

Moreover, like Colombia, both of these Balkan states suffer from endemic political corruption. According to the WGI measurement on the control of corruption, unlike the more positive trends in their rule of law scores, corruption is growing or remaining problematic. For example, in $\mathrm{BiH}$, its score in 2005 was -0.20 but in 2015 it was -0.37. In Kosovo's first assessment in 2003, corruption was -0.81 , yet in 12 years, it only improved to a $-0.52 \cdot{ }^{109}$ Certainly, the lack of judicial independence previously identified contributes to this pandemic, but there is also a lack of political will to tackle this problem. The European Commission noted in its 2012 and 2016 reports on BiH that corruption is fueled by the failure to enforce anti-corruption laws, weak criminal sanctions for those found guilty and a lack of prosecutorial capacity. $(15,16)$

In the UN's quarterly reports, its discussion of those arrested or on trial for corruption reads like a laundry list of Kosovo's political leadership. Former Assembly Speaker Nexhat Daci was convicted of corruption in 2010, former Minister of Communities and Returns Slavisa Petkovic was on trial in 2012 for the misappropriation of funds and ironically, the Kosovo prosecutor in charge of the anti-corruption task force was arrested for corruption in 2012 as well. (UNSYG October 31, 2011, 16, UNSYG April 27, 2012, 15) Clearly, with the political landscape permeated with such a high level of political corruption, the rule of law cannot become a consolidated feature in either country, yet for corruption to be addressed, the rule of law, particularly its institutions,

\footnotetext{
${ }^{109}$ Like the rule of law, control of corruption is measured each year from -2.5 (poor governance) to 2.5 (optimal governance of corruption).
} 
must become stronger and more independent. While a more meaningful discussion of the rule of law, corruption and transitional justice is beyond the scope of this analysis, this issue is identified to highlight the fact that even with its best efforts, transitional justice implemented in a corrupt environment can only do so much. In light of the disappointing results in $\mathrm{BiH}$ and Kosovo, it is useful to compare the four cases of this analysis against one another. Did these countries experience the same inhibiters, or can we identify common rule of law end goals where transitional justice positively impacted all four? To answer these and other questions, $\mathrm{BiH}, \mathrm{Kosovo}$, Colombia and Peru are presented together in Chapter Five. 


\section{Chapter 5}

\section{Peru \& Final Thoughts}

\section{Introduction}

Unlike the previous two chapters, Chapter Five is formatted differently, mixing a brief country case study (Peru) with the overall concluding analysis. ${ }^{110}$ Although the findings reached for Peru are tentative, this country is an important case since, as will be discussed below, it should be theory-affirming for those championing a domestic approach to transitional justice. Moreover, as outlined in Chapter Two, Peru is the one country in this study that supports the path dependency thesis as it relates to the rule of law in post-conflict states. Therefore, although in-country fieldwork was not done in this Andean country, it is important to address why a country that relied upon domestic design and implementation for its transitional mechanisms, as well as used a justice balance, has struggled to improve its rule of law. Much like the other countries discussed in Chapters Three and Four, transitional justice in Peru was not able to produce change in Kleinfeld's five rule of law reform end goals due to some of the same reasons and inhibiters Colombia, $\mathrm{BiH}$ and Kosovo also experienced.

Upon outlining the design, mechanisms and implementation of transitional justice in Peru, this chapter turns its attention to the wider implications the findings from these four countries provide for understanding the relationship between transitional justice and the rule of law. More specifically, the parameters of a theory of change, i.e., where and how does transitional justice improve the rule of law is sketched, and this chapter revisits

\footnotetext{
${ }^{110}$ Due to financial and timing constraints, fieldwork was not conducted in Peru as part of this analysis. The brief discussion of Peru is based upon the quantitative findings in Chapter Two and insights from the existing literature.
} 
the importance, or lack thereof, of model design (international, mixed or domestic). Finally, the chapter and analysis conclude with some recommendations on how to adjust the implementation of transitional justice in order to avoid common post-conflict inhibiters while also identifying avenues for further research.

Peru

The trajectory of Peru's rule of law differs from the other three cases covered in this study. Unlike Colombia, $\mathrm{BiH}$ and Kosovo, the rule of law in this Andean state regressed during the implementation of transitional justice, and it has only slowly rebounded to a level similar to where it began in 1996. For instance, in 1996, Peru's rule of law was a -0.65 , but by 2007 it had fallen to -0.78 . Since 2008 , this metric has slowly risen, reaching -0.53 in 2015. In comparison, Peru's neighbor Colombia, began its journey at -0.89, yet it has now surpassed Peru with a -0.31. (WGI; see Chapter Two, p.31 for scores for all years) Moreover, unlike Colombia whose mean rule of law score improved following the implementation of transitional justice, Peru's is relatively the same, i.e., a -0.67 (1996-2000) before and a -0.63 after the introduction of transitional justice (2001-15).

The stagnation of Peru's rule of law is theoretically perplexing. Peru designed and executed a full range of transitional mechanisms, including coupling retributive with restorative elements. Local trials were held, a truth commission was convened, amnesties and pardons were given and reparations provided. According to the literature that has been discussed throughout, Peru meets the domestic criteria for having sufficient local ownership over these processes, and the combination of mechanisms meets the needs of a justice balance. (Turner 2008, 138; Lambourne 2009, 31; Olsen, Payne and Reiter 2010) 
While any conclusions offered here are limited, Peru does fit the path dependency thesis outlined by Haggard and Tiede (2014), and its relatively weak rule of law is consistent with the general struggles of post-conflict states. It should also be remembered that although there have been modest improvements in Colombia, $\mathrm{BiH}$ and Kosovo, the ability of transitional justice to effect change within the rule of law is small, and not unlike these other countries, Peru also wrestles with a culture of impunity and corruption. ${ }^{111}$

Peru's internal conflict during the 1980s and early 1990s, much like Colombia's, involved the state, leftist guerillas and government-aligned paramilitaries all engaged in hostilities related to control of the Andean highlands. According to Peru's truth commission, an estimated 61,000 to 77,000 individuals were killed during this struggle, and culpability for these crimes fell at the feet of both the guerillas and state security forces. ${ }^{112}$ (Root 2012, 88-89) In addition to the violence, the government was also highly corrupt and centralized under the leadership of President Alberto Fujimori (1990-2000). Consequently, although hostilities had largely abated by 1992 with the capture of the head of the Shining Path, Fujimori resisted attempts to initiate transitional justice, and it would not be until after Fujimori resigned that transitional proceedings would begin.

At the heart of Peru's transitional justice was the Truth and Reconciliation Commission (CVR by its Spanish acronym), which was established in 2001 with the mandate to assemble a record of events from 1980 through 2000, as well as refer cases

\footnotetext{
${ }^{111}$ According to the WGI, corruption is growing in Peru. In 2000, the ability of the government to control corruption was low (-0.49), but by 2015 it had worsened to $(-0.60)$.

112 The guerillas of the Shining Path committed 215 massacres while the state was responsible for 122 . (Root 2012, 89)
} 
for prosecution and develop recommendations for government reform. At the time of its creation, the CVR enjoyed $83 \%$ of the public's support. (Ibid, 56) This truth commission released its findings two years after its creation, and following this report, Peru turned its attention to criminal proceedings. These trials consisted of 47 cases referred to the courts by the CVR, the re-trial of 1,400 terrorism-related cases adjudicated under the Fujimori era, and most visibly, the 2007-09 trial of former President Fujimori. According to Iglesias, the re-trials were generally successful and fair, but of the 47 cases referred by the CVR, only a "handful" have moved forward due to the unwillingness of the security forces to cooperate. $(2012,232)$ As for Fujimori, his 2009 conviction and 25-year prison sentence for abuse of authority, corruption and human rights violations is generally heralded as a positive development in Peruvian attempts to combat impunity.

In addition to trials and truth-telling, an amnesty law was passed under Fujimori for the military and police, which although it was later overturned, some pardons were issued for once-convicted terrorists after 2003. Peru's reparations, which have included both individual and collective, have been slow in reaching the approximately 285,000 registered victims. (Root 2012,134) Although not without flaws, this transitional framework meets the theoretical criteria for success. Yet, as is demonstrated by the stagnation in its mean rule of law score, transitional justice had little to no effect in Peru.

For example, within the rule of law reform goals of establishing a government subordinate to the law and ensuring the equality of all before it, the Bertelsmann Transformation Index (BTI) reports no changes in Peru despite the truth being told about government involvement in conflict crimes and Fujimori's conviction. According to the BTI, from 2006 to 2016, the independence of Peru's judiciary and ability to prosecute 
abuse of government office has remained at a six, which is in-between having a score representing serious deficiencies (a four) and being generally on the right track (a seven). Why this indicator is "stuck" despite a high-profile trial and a balanced account of events is difficult to explain, although one possible reason could be that the failure to hold many in the security forces accountable for their crimes has contributed to a sense of general impunity. As Root $(2012,94)$ notes, transitional justice in Peru did little to change existing structures of power; those in command during the war remained in positions of authority even after Fujimori resigned.

In terms of law and order, the defeat of the Shining Path, and the subsequent tempering of military operations helped to dramatically reduce civilian casualties. Yet, as the crime statistics illustrate, transitional justice did not deter non-conflict related violent crime. In fact, even with transitional justice, crime in Peru has skyrocketed, which helps explain why the level of the rule of law declined from 2005-2007. For instance, in 2000, there were approximately five homicides per 100,000 people in Peru; by 2005 there were 11 and in 2008 there were 12. As for assaults, in the early years of transitional justice there were 55 per 100,000 (2004), yet by 2007 this number had increased to 192. (UNODC) Table 5.1 illustrates Peru's rise in crime.

Table 5.1: Crime Rates in Peru Since 2000

\begin{tabular}{|c|c|c|}
\hline Year & Homicides (per 100,000) & Assaults (per 100,000) \\
\hline 2000 & 5 & N/A \\
\hline 2004 & 6 & 55 \\
\hline 2005 & 11 & 192 \\
\hline 2007 & 10 & \\
\hline
\end{tabular}




\begin{tabular}{|c|c|c|}
\hline 2009 & 10 & 191 \\
\hline 2011 & 10 & 194 \\
\hline 2014 & 7 & 211 \\
\hline
\end{tabular}

*Data is from UNODC.

While explaining the dramatic rise in violent crime in Peru is beyond the scope of this analysis, what can be observed is that transitional justice, particularly trials, did little to deter individuals from killing and assaulting others. The demonstration effect from events such as the Fujimori trial does not appear to translate into deterring non-conflict crimes, which was also the case in Colombia. While there are likely strong economic and societal factors underlying this rise in crime, the fact that these trials were not predictable nor efficient, i.e., only a handful of security forces stood trial, may have contributed to a weakening of the deterrence effect.

As for transitional justice's influence in promoting a government respectful of human rights, it does not appear that the range of mechanisms used were immediately successful. According to the Political Terror Scale (PTS), political violence, i.e., violence carried out by the state, has persisted despite efforts to bring to light prior crimes. For instance, in 1996, the PTS assessed political violence as widespread (a four); from 19972004 , the level of these types of crimes dropped to a three, which represents extensive political imprisonment and the likelihood of state violence. From 2005-09 this improved to a two, but from 2010-14, it regressed again to a three. Only in 2015 did political violence return to being rare or exceptional (a two). (Gibney et al. 2016)

Although this discussion of transitional justice in Peru is brief, it does shed light on some of the factors that have contributed to a relatively fixed level of the rule of law. 
Surprisingly, a CVR that found culpability for human rights crimes amongst both the state and guerillas, along with a trial of a former president, failed to improve measures of governmental accountability. Although not regressing, Peru's score of a six over a tenyear span on both judicial independence and the ability to prosecute abuses of government office indicates that impunity remains problematic. Moreover, transitional justice did not serve as a deterrent, at least not when it comes to non-conflict related violent crimes, and a government committed to human rights is only slowly emerging. In light of these persistent challenges, why did a justice balance approach to transitional justice fail to promote the rule of law?

Although Peru's CVR initially enjoyed widespread public support, backing for this truth commission waned over time. In 2003, the year it issued its report, public interest in the truth commission's findings and recommendations had subsided as the situation stabilized, politics returned to normal and the military recovered its privileged position within society and the government. (Root, 162) Moreover, while many Peruvians wanted to see former President Fujimori account for his crime of corruption, there is still a strong base of support for the former president because he defeated the guerillas. Assessing the public's attitude toward Fujimori and the conflict in general, Root opines that many Peruvians are willing to tolerate human rights violations as long as they served a greater purpose, i.e., ridding society of the Shining Path. $(2012,125,162)$ This finding is supported by the public's reaction to Peru's Constitutional Court decision of 2003 that called for the re-trial of convicted terrorists under the Fujimori regime. According to one opinion poll, $77 \%$ of Peruvian respondents disagreed with this decision because they feared it would allow terrorists/guerillas to go free. (Ibid, 102-03) 
Overall, transitional justice, at least those parts that seek to hold the state accountable, are still generally viewed as anti-government, pro-rebels. (Iglesias 2012, 237-39) Consequently, although Peruvians may have initially supported the truth, it is not clear which version of the truth they were prepared to accept. Moreover, while Fujimori and some of his lieutenants were held accountable, there was never a purge of those in the military or society that carried-out or condoned state crimes. Subsequently, transitional justice appears to have had little to no effect on the rule of law, and other factors, which are beyond the scope of this analysis, continue to exert a strong negative influence.

\section{Final Thoughts}

It is important to recall that within the literature, scholars and practitioners are only beginning to understand the state-level effects of things such as trials and truth commissions in post-conflict environments. The proceeding four chapters, as well as this chapter's brief discussion on Peru, address one small piece of this larger puzzle, namely to identify the relationship between transitional justice and the rule of law. In keeping with this fundamental question, this analysis tested the hypothesis that domesticallygenerated and implemented mechanisms are better suited in delivering positive change than those processes fully imposed and executed by the international community.

While seeking answers to these important questions, this analysis first found that despite previous assertions (Haggard and Tiede 2014), the rule of law is not always path dependent in post-conflict states. In Colombia, $\mathrm{BiH}$ and Kosovo, the rule of law improved appreciably both during a conflict (Colombia) and after one ( $\mathrm{BiH}$ and Kosovo). Although Haggard and Tiede's path dependency thesis was not entirely discounted, 
namely Peru exhibited this tendency, the rule of law can improve slowly over time. Yet, while improvements were recorded in three of this study's four cases, all four nations still have comparatively low levels of the rule of law, and this element of society is not yet a consolidated feature. For instance, despite consistent improvements from 2005-13, the rule of law is now declining in $\mathrm{BiH}$, moving from a -0.15 in 2013 to a -0.29 in 2015.

Moreover, although Sikkink (2011) and Weiffen (2012) identify a positive relationship between transitional justice and the rule of law, evidence from this analysis indicates that these findings are overstated, and improvements were found in only a few of Kleinfeld's five rule of law reform end goals. ${ }^{113}$ In Colombia, BiH and Kosovo, transitional justice did help develop the rule of law, but the impact was minimal. Overall, transitional justice was found to produce change in three areas. First, transitional mechanisms, namely the restoration of property, improved the protection of property rights. In Colombia, after Law 1448 (2011) was passed, the WGI's metric for property rights went from a 30 to a 50 out of 100 . Although more modest, improvements in Bosnia's property rights, which can be linked to transitional policies, also contributed to higher rule of law scores in this Balkan state.

Additionally, transitional mechanisms, principally amnesties coupled with demobilization, were also factors in improving law and order and human rights in Colombia. The amnesties provided to illegal combatants in accordance to the terms of the Justice and Peace Law removed from the general conflict approximately 50,000 guerillas and paramilitaries. Their absence from the battlefield coincided with reductions in

\footnotetext{
113 The five end goals are a government subordinate to the law, the equality of all before the law, the existence of law and order, predictable and efficient justice and upholding human rights. These five indicators are useful because they cover both the procedural and substantive domains of the rule of law.
} 
conflict-related crimes and human rights violations. The cessation of hostilities also contributed to improvements in these two domains within $\mathrm{BiH}$ and Kosovo, although changes were much slower. Finally, the ICTY's capacity building efforts, along with the use of a hybrid tribunal in Bosnia, aided in this state's ability to adjudicate war crimes cases more predictably and efficiently. In fact, out of the three countries that had improvements to their rule of law scores, Bosnia's war crimes courts have been the most productive, completing over 361 cases, covering more than 530 defendants since 2004. Colombia has only processed 47 cases since 2005 , and although figures are only available through 2013, Kosovo has finished 63 cases.

Obviously, these were not the only changes to the rule of law, but they were the only ones able to be tied to transitional justice. For example, the WGI found that political violence had declined and civil liberties had improved in both $\mathrm{BiH}$ and Kosovo. Yet, following careful investigation, it is apparent that these improvements were due to other factors, such as international oversight missions with executive authorities, robust international military and police deployments and behavioral incentives tied to independence and EU membership. Moreover, in Colombia, its level of state-instigated political violence has also subsided, moving from a five to a three in the Political Terror Scale, but attributing this directly to transitional justice, particularly when agents of the state were not subjected to the Justice and Peace process, is a stretch. Like BiH and Kosovo, the reduction in the general conflict over time, and international pressure, such as the U.S. linking some of its assistance to better performance on human rights, were likely more important factors in producing this decline. 
In addition to identifying the nature of the relationship between transitional justice and the rule of law, this analysis also sought to uncover which model of transitional justice (international, mixed or domestic) was better suited to facilitate these changes. Recall that according to the descriptive statistics presented in Chapter Two, as well as the histogram presented below in Figure 5.1, the domestic and mixed models appear better suited to facilitate improvements in the rule of law when compared to international processes. For example, in Colombia, its mean rule of law score increased noticeably after the introduction of transitional justice, and the differences in means between Bosnia's and Kosovo's international and mixed eras are statistically significant.

Figure 5.1: Models of Transitional Justice and Rule of Law Scores

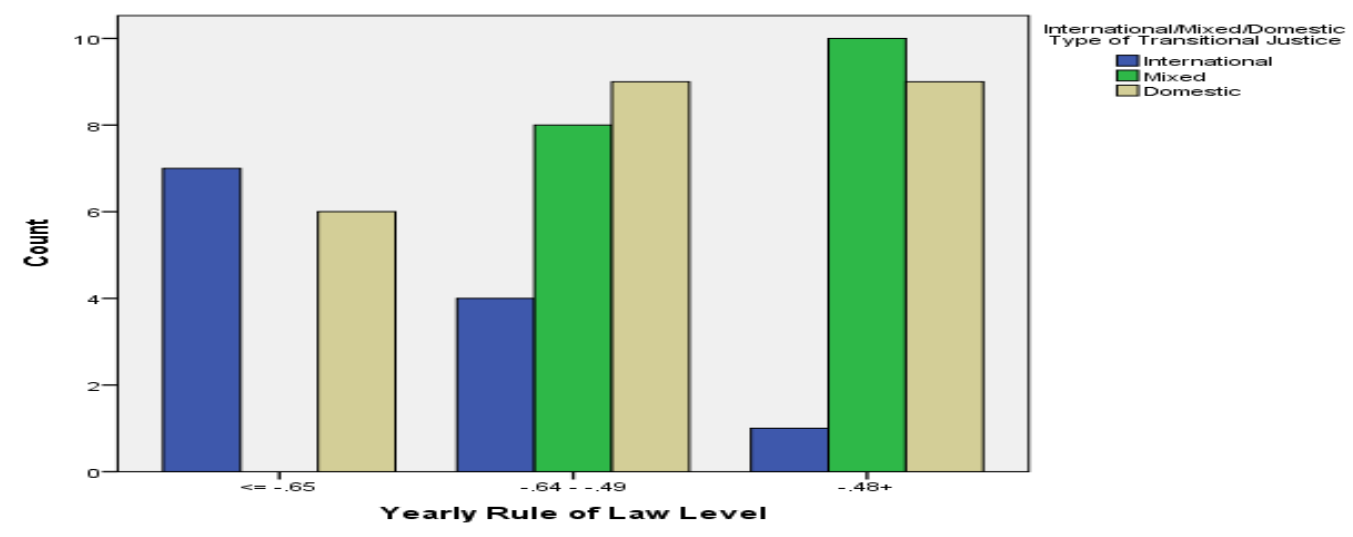

*Data is from the WGI, and the histogram represents all four countries in this study.

Yet, while it appears that processes with at least some domestic design and execution will help lead to improvements in the rule of law, the evidence is inconclusive. For instance, Peru's rule of law actually regressed during its purely domestic processes, and problems identified under Bosnia's and Kosovo's international models persist under the mixed. In fact, in $\mathrm{BiH}$, its judiciary has become more corrupt and politically susceptible after local institutions assumed more responsibilities for transitional justice, and its overall level of the rule of law is declining under a mixed model. In addition to 
these findings, the results from the regression analysis demonstrate that none of the models of transitional justice were statistically significant, although it is acknowledged that the model would benefit with more cases and observations. Furthermore, although the rule of law in $\mathrm{BiH}$ and Kosovo showed little improvement while ICTY trials dominated the transitional justice landscape, this does not support the conclusion that all international models are ineffective viz-a-viz the rule of law.

It could be that only those international models employed by $\mathrm{BiH}$ and Kosovo did not work because of their own structural flaws. According to Garbett, there are two ways local support can emerge from an internationally-led judicial process. First, local legal traditions and culture should be incorporated into the proceedings, and secondly, individuals from the region need to be engaged in all the aspects of the court, beginning with its creation and all the way through to the final verdicts. $(2012,70)$ Unfortunately, the ICTY has been both geographically and culturally distant, and legal personnel from the countries where the defendants originated have not been properly involved.

The international ad-hoc tribunal established for the former Yugoslavia sits in The Hague, Netherlands, and it did not conduct trials in any of the countries where the crimes occurred, although its statute did allow it. Moreover, the lawyers and judges were seconded from UN member states outside of the Balkans, and according to its statute, international law superseded any local law or tradition. Subsequently, it is clear from the start that the ICTY was operating from a disadvantage in terms of developing local partnerships and support.

Furthermore, this court's failure to develop at its inception a comprehensive outreach campaign left the proceedings open to local interpretations, which were plagued 
by ethnic bias. Orentlicher notes that an outreach campaign was not established until six years after the ICTY's creation, which by then individuals had already co-opted the narrative of the Tribunal for their own political purposes. $(2010,14,20)$ This delay, along with the lack of inclusion of local traditions, left many in the region confused with the ICTY's proceedings. According to Subotic, one of the reasons the ICTY was a "great disappointment" in $\mathrm{BiH}$ was due to its inability to explain its cases to those it was created to serve. (2009, 132-34) For example, Bosnians were generally not familiar nor comfortable with legal tools like plea bargains, reduced sentences for cooperation or early release since these were not part of their pre-war legal culture. (Ibid, 51-52)

Following my interviews in $\mathrm{BiH}$ and Kosovo, the general consensus among international and local officials, as well as civil society, is that the greatest contributions of the ICTY are the establishment of an impartial record of events and the prosecution of individuals that might otherwise have escaped justice. ${ }^{114}$ While these are certainly no small feats, this type of international justice did not allow the people in the Balkans to experience the law. One of the reasons Sikkink argues that human rights trials were effective in promoting the rule of law in Latin America was because these proceedings were embedded in local courts; citizens participated in the design and adjudication of the trials, i.e., the people discovered the law together. $(2011,83)$

Although the majority of Bosnians and Kosovars support justice, the trials were clouded by physical and cultural distance, and many ethnic communities became disillusioned with the court's work because of perceived biases. To be fair, a court of this

\footnotetext{
${ }^{114}$ Interview supra $\mathrm{n} 69$.

Interview supra $\mathrm{n} 94$.

Interview supra $\mathrm{n} 78$ (Humanitarian Law Center).
} 
nature will never please everyone; the fact that it tried individuals from all major ethnic communities reflects its efforts to remain impartial in the disputes that plagued and continue to fester in the former Yugoslavia. Yet, it is also reasonable to conclude that the nature of this justice, i.e., distant and culturally different, contributed to its inability to elicit widespread local support and thereby promote major rule of law changes. Furthermore, both of these international models were too reliant upon accountability proceedings, and they did not couple these retributive elements with restorative policies.

As discussed in Chapter Four, the initial responsibility for the failure to employ a justice balance does rest solely at the feet of local government officials or civil society in $\mathrm{BiH}$ and Kosovo. The ICTY was hesitant to support a truth commission in BiH over fears of resource and witness competition, and the $\mathrm{UN}$ mission in Kosovo also failed to use its authority to establish any mechanisms for truth-telling or meaningful victim reparations for reasons that are not clear. Presently, both the ICTY and UN have significantly less influence in these Balkan states, and current international efforts and pressure for these countries to do more on transitional justice is now channeled through the European Union.

As each of these countries take steps towards EU membership, bureaucrats in Brussels are using the accession process to encourage passage of comprehensive transitional justice strategies. Moreover, the EU is also providing tangible financial assistance to Bosnian courts and prosecutors, and in Kosovo, EULEX is acting in a more direct fashion by continuing to adjudicate with Kosovar judges and prosecutors local war crimes cases. Although the international community remains active in each Balkan state, the EU's approach is different from that of its predecessors. Following the immediate 
cessation of hostilities, the international authorities in $\mathrm{BiH}$ and Kosovo each possessed executive mandates they were not afraid to use. Currently, most of these authorities have now been transferred to local institutions, and according to both international and local officials, the EU is hesitant to take a heavy-handed approach in forcing the passage of theses respective transitional justice strategies. Instead, the EU is attempting to foster local initiative and ownership over these processes. ${ }^{115}$

While more local responsibility for transitional justice is sorely needed in $\mathrm{BiH}$ and Kosovo, it is fair to question whether this will be enough in light of the persistence of ethnic politics. But, the hope is that with the carrot of EU membership, ethnicity as the driving force in politics will fade over time. If a more European future is embraced instead of the current ethnic vitriol, there is the possibility that new mechanisms of transitional justice could be successful, but Subotic's findings that local elites throughout the Balkans used the ICTY for their own political purposes should not be forgotten. (2009)

Officials in both $\mathrm{BiH}$ and Kosovo could continue offering just enough cooperation to satisfy Brussels' demands while ignoring meaningful reform. Ultimately, the responsibility for the passage of comprehensive transitional justice strategies lies at the feet of the citizens of both states. Leaders must be elected that are willing to shun the ethnic-centered politics that has dominated the post-war period, and then society must demand that more be done. Unfortunately, whether there is enough momentum and

\footnotetext{
115 Interview supra n 78.

Interview supra n 93.

Interview supra $\mathrm{n} 79$ (GoK consultant on transitional justice).
} 
support within these societies to actively lobby for things such as reparations and truth approximately two decades after these conflicts is unclear.

Returning to the larger transitional justice context, while this analysis did not seek to address issues of mechanism sequencing or timing, it is important to briefly assess whether the sequencing and timing of mechanisms played a role in the development of the rule of law in these four states. Unfortunately, due to the failure of two $(\mathrm{BiH}$ and Kosovo) of this study's four cases to utilize multiple mechanisms, it is difficult to draw any conclusions from this data about the sequencing of mechanisms. For example, Colombia launched its transitional justice mechanisms together, convening trials while also pursuing the truth and distributing reparations. Based upon the statistical and qualitative findings this simultaneous pursuit of truth, justice and reparations appears to have paid-off, at least compared to its Andean neighbor.

In Peru, it initially emphasized truth over accountability. Whether this delay in trials helps explain some of Peru's rule of law problems is not clear due to the limited assessment of this case. What is logical to assume, however, is that some elements of Peruvian society may have felt disillusioned with transitional justice since many of those responsible for human rights violations failed to stand trial for their crimes a decade or more after they were committed. This delay in justice may be responsible for the failure to improve some elements of the rule of law, particularly those that focus on the equality of all before the law. Yet, due to the limitations of this study's cases and available data, any conclusions stemming from the Colombia/Peru comparison regarding sequencing are inconclusive and tentative at best. 
On the surface, these findings may seem disappointing for practitioners and scholars who expect a more robust, positive effect from transitional justice. While admittedly far from optimal, transitional justice can play a greater role in developing the rule of law if implementers are aware and address powerful inhibiters that block more meaningful change. In all of the cases in this study, the lack of institutional capacity and financial resources stymied the implementation of transitional justice. For example, part of the reason Colombia has been unable to sentence more than 47 demobilized criminals, as well as distribute judicial reparations, is due in part to insufficient numbers of investigators, prosecutors and judges. In $\mathrm{BiH}$ and Kosovo, the latter still only had one prosecutor for war crimes in 2016, and while not the primary reason, the lack of funding has hindered the implementation of comprehensive transitional justice strategies in both of these Balkan states.

Along with a lack of institutional capacity and resources, all four countries also share in the persistence of political corruption. Colombia's corruption has reached a level where approximately $10 \%$ of its 2017 national budget is being siphoned-off for illicit purposes. (Alsema 2016) While the connection between political corruption and transitional justice may not be obvious at first, the fact that billions of dollars are being diverted for illegal enrichment while victims continue to suffer, illustrates the negative impact corruption can have on transitional programs.

While both of the aforementioned inhibiters are strong, Colombia also wrestles with two specific ones. The continuation of its conflict and inability of the state to govern former conflict regions has allowed revictimization to occur, discourages victim participation in things like truth-telling and slows down the return of property. For 
example, in 2015 the government's Victims' Unit recorded more than 170,000 people effected by the conflict that year, and despite an agreement with the FARC in 2016, there were more than 69,000 victims last year. (Victims' Unit) Moreover, the failure of the government to control all of its territory allows drug trafficking to grow, which serves as a powerful incentive for illegal combatants not to demobilize. In BiH and Kosovo, transitional justice is being diluted by a prioritization of ethnicity over dealing with the past. Chapter Four highlighted the fact that in both Balkan nations, impunity is tolerated, and sometimes celebrated, and ethnic attacks are ignored as long as these behaviors are targeted against other ethnic communities.

Clearly, some of these inhibiters are to be expected in post-conflict environments, especially the lack of resources. Unfortunately, not much can be done to alleviate this problem unless donors are willing to increase their assistance. Yet, for some of the others, there are solutions. Primarily, post-conflict states should employ a justice balance. Colombia's institutional deficiencies in the judiciary were compounded by this country's reliance upon the courts to deliver truth, justice and reparations. Now, after more than a decade of experience, Colombia has implemented a more efficient and less costly administrative reparations program, modified its prosecutorial strategy and has committed to establishing a truth commission. In BiH and Kosovo, proponents of transitional justice are continuing to advocate the adoption of comprehensive transitional justice strategies that will restore the victims through monetary reparations, establish the truth and reform corrupt institutions. While the need remains, the implementation of these strategies is more difficult now as international attention and assistance wanes, but the fact remains that many victims still want more than simply trials. 
In addition to identifying the need to balance trials with reparation programs that do more than return property, there is also a critical need for more comprehensive lustration. The vetting of judges and prosecutors is important, but in all cases, politicians and members of the security forces involved in state crimes remain in positions of authority. Trials of human rights violators were stymied in Peru because of the lack of the military's cooperation, and in Bosnia and Kosovo, former political and military leaders with at best questionable pasts are being elected for some of the highest offices. While it is recognized that removing and/or precluding popular individuals from political office is sensitive and difficult to do, the permeation of a dangerous ethnic ideology in $\mathrm{BiH}$ and Kosovo are examples of the results of not doing so. In both states, politicians still capitalize on an ethnic narrative to maintain their power while allowing ethnic animosities to fester. Whether the pull of EU membership can dilute this vitriol is unclear.

Yet, with a justice balance, there is a caveat. While countries should strive to mix retributive with restorative elements, governments should not promise to do more than what they can deliver. Colombia's pledge to prosecute more than 5,000 individuals and provide judicial reparations have largely gone unfulfilled, thereby exasperating societal tensions. Promising more than a government can deliver also erodes trust in institutions, an ingredient central to the rule of law, and one that needs to be cultivated in post-conflict societies.

Way Ahead

Conflict and post-conflict environments are by nature unstable. Consolidating the transition from war to peace entails many challenges, one of which is building the rule of 
law. As Haggard's and Tiede's findings illustrate, establishing predictable and efficient institutions, ensuring the equality of all before the law and instilling a new ethos regarding the treatment of others is not easy nor does it naturally follow the termination of a conflict. Yet, the results of this analysis are somewhat more optimistic, and while modest, transitional justice can help. While this study aids in the understanding between transitional mechanisms and the rule of law, it does have its limitations. For instance, the regression analysis includes only four cases, and in each, there are observations missing. Therefore, a more robust statistical analysis of these variables that encompasses more cases and observations could help establish whether one model is more effective.

In addition to expanding this analysis, there are two other important, unanswered questions that emerged during this investigation. Clearly, Colombia's ability to implement transitional justice was and is hindered by the inability of the state to expand its authority to previous conflict zones. Because of this, revictimization continues and criminality thrives. Consequently, scholars and practitioners should be concerned with addressing the sequencing between state-building and transitional justice, along with whether things such as trials, reparations and government reforms can be used to aid in the development of the state.

Since the foundational work done by Snyder and Vinjamuri (2003-2004), little has been done to empirically test these authors' claim that transitional justice done in the absence of state/institutional capacity could be harmful. While many appreciate the need for institutions to carry-out transitional justice, in many post-conflict states these institutions struggle to meet even the most basic governing demands. This therefore, raises several important questions, such as can transitional justice be a tool for building 
state capacity or should transitional justice wait until there is sufficient institutional support?

Moreover, in each of the four cases, corruption served as a serious inhibiter to transitional justice and the rule of law. Resources that are needed to restore the victims and fund costly expenditures such as trials are being wasted. The idea that the scope of transitional justice should expand to include political corruption is being debated. For instance, Andrieu argues that since grievances towards corruption can lead to political transitions, i.e., the Arab Spring, these crimes should be dealt with within the space created by transitions. While logical, Andrieu also cautions that adding new responsibilities to already overloaded courts and truth commissions may redirect the focus away from serious human rights violations. (2012)

Based upon the findings in this analysis, concerns centering around weak institutions have merit. Yet, the political space created by a transition, particularly when there is a change in government, is an attractive opportunity to deal comprehensively with crimes of the previous regime. What is needed now is work that investigates the sequencing and institutional needs to do both. In light of these gaps, along with the remaining work to be done on transitional justice and the rule of law, transitional scholars will remain busy. Yet, the recent empirical work has greatly advanced our understanding of transitional justice, which by the unfortunate events that continue to transpire in places like Syria, will remain an important tool for consolidating peace and addressing the needs of conflict victims. 


\section{REFERENCES}

Alcala, Pilar Riano and Maria Victoria Uribe. 2016. "Constructing Memory Amidst War: The Historical Memory Group of Colombia." International Journal of Transitional Justice, 10: 6-24.

Alsema, Adriaan. 2016. "10\% of Colombia Government budget lost to corruption: Inspector General," Colombia Reports, 24 October 2016. http://colombiareports.com/10colombia-government-budget-lost-corruption-inspector-general/ (January 28, 2017).

Andrieu, Kora. 2012. "Dealing With a 'New' Grievance: Should Anticorruption Be Part of the Transitional Justice Agenda?” Journal of Human Rights 11(4): 537-57.

Arthur, Paige. 2009. "How 'Transitions' Reshaped Human Rights: A Conceptual history of Transitional Justice.” Human Rights Quarterly 31 (May): 321-67.

Aviles, William. 2006. "Paramilitarism and Colombia's Low-Intensity Democracy." Journal of Latin American Studies 38/02 (May): 379-408.

Balasco, Lauren Marie. 2013. "The Transitions of Transitional Justice: Mapping the Waves from Promise to Practice." Journal of Human Rights (12): 198-216.

Bargent, James, "Colombia Raids 'Luxury’ Prison Wing," InSight Crime, 10 July 2015. http://www.insightcrime.org/news-briefs/colombia-raids-prison-luxury-wing (January 27, 2017).

Bedner, Adriaan. 2010. "An Elementary Approach to the Rule of Law." Hague Journal on the Rule of Law 2:1(March): 48-74.

Bergman, Marcelo. 2012. "The Rule, the Law, and the Rule of Law: Improving Measurements and Content Validity.” The Justice System Journal (33:2): 174-93.

Bertelsmann Transformation Index. www.bti-project.org/en/index/ (October 6, 2016).

Binningsbo, Helga Malmin, Cyanne E. Loyle, Scott Gates, and Jon Elster. 2012. "Armed Conflict and Post-Conflict Justice, 1946-2006: A Dataset." Journal of Peace Research 49(5): 731-40.

Cawley, Marguerite, "Election Results Show Persisting Criminal Influence in Colombia," InSight Crime, 11 March 2014. http://www.insightcrime.org/news-briefs/colombiaelection-results-show-persisting-criminal-influence-in-politics (January 27, 2017).

Carothers, Thomas. 1998. "The Rule of Law Revival.” Foreign Affairs 77:2(MarchApril): 95-106. 
Carrillo, Arturo. 2009. "Truth, Justice, and Reparations in Colombia: The Path to Peace and Reconciliation?" In Colombia: Building Peace in a Time of War ed. Virginia Bouvier. Washington, D.C: United States Institute of Peace, 133-58.

Center for Historical Memory. 2012. "Encuesta Nacional: Que Piensan Los Colombianos Despues de Siete Anos de Justicia y Paz?"

http://www.centrodememoriahistorica.gov.co/justicia-y-paz/que-piensan-loscolombianos-despues-de-siete-anos-de-justicia-y-paz (May 9, 2017)

Collak, Petrit. 2015. "Kosovo Parliament Votes for New War Crimes Court," Balkan Insight, 3 August 2015. http://www.balkaninsight.com/en/article/kosovo-parliament-newwar-crimes-court-vote-08-03-2015 (April 4, 2016).

Colombia Ministry of Justice. 2015. "Ten Years Later: An Assessment of the Justice and Peace Special Criminal Process." DRAFT report. (Given to the author by Colombian MOJ, March 2016).

Colombia Victims’ Unit. http://rni.unidadvictimas.gov.co/RUV (May 3, 2017).

Correa, Cristian. 2015. "From Principles to Practice: Challenges of Implementing Reparations for Massive Violations in Colombia." International Center for Transitional Justice. October. https://www.ictj.org/publication/principles-practice-challengesimplementing-reparations-massive-violations-colombia (January 29, 2016).

Dancy, Geoff \& Eric Wiebelhaus-Brahm. 2015. "Timing, Sequencing, and Transitional Justice Impact: A Qualitative Comparative Analysis of Latin America." Human Rights Review (16): 321-42.

Di Lellio, Anna and Caitlin McCurn. 2012. "Engineering Grass Roots Transitional Justice in the Balkans: The Case of Kosovo.” Eastern European Societies \& Politics 27(1): 129-48.

Dragovic-Soso, Jasna. 2016. "History of a Failure: Attempts to Create a National Truth and Reconciliation Commission in Bosnia and Herzegovina, 1997-2006," International Journal of Transitional Justice 0: 1-19.

Dijkstra, Hylke. 2011. "The Planning and Implementation of the Rule of Law Mission of the European Union in Kosovo," Journal of Intervention and Statebuilding 5(2): 193 210.

European Union Rule of Law Mission to Kosovo (EULEX). 2009. "EULEX Programme Report 2009." http://www.eulex-kosovo.eu/docs/accountability/EULEX-

PROGRAMME-REPORT-July-2009-new.pdf (July 23, 2013). 
European Union Rule of Law Mission to Kosovo (EULEX). 2010. "EULEX Programme Report 2010.” http://www.eulex-kosovo.eu/eul/repository/docs/EPR_2010_2.pdf (May 3, 2017).

European Union Rule of Law Mission to Kosovo (EULEX). 2011. "EULEX Programme Report 2011.” http://www.eulex-kosovo.eu/eul/repository/docs/EPR_2011_2.pdf (May 3, 2017).

European Union Rule of Law Mission to Kosovo (EULEX). 2012. "EULEX Programme Report 2012.” http://www.eulex-kosovo.eu/en/pressreleases/0312.php (July 23, 2013).

European Union Rule of Law Mission to Kosovo (EULEX). 2013. "EULEX and War Crimes." http://www.eulex-kosovo.eu/en/news/000427.php (May 3, 2017).

European Commission. Bosnia and Herzegovina Progress Reports (2005-15). http://europa.ba/?page_id=208 (May 2, 2017).

Fiscalia (a). http://www.fiscalia.gov.co/jyp/wp-content/uploads/2016/06/INFORMEGENERAL-2016-MAY-31.pdf (December 17, 2016).

Fiscalia (b). http://www.fiscalia.gov.co/jyp/direccion-de-fiscalia-nacional-especializadade-justicia-transicional/ley_justicia_y_paz/ (January 23, 2017).

Fletcher, Laurel, Harvey Weinstein, and Jamie Rowen. 2009. "Timing and the Dynamics of Transitional Justice: A Historical Perspective." Human Rights Quarterly 31(1): 163220.

Fukuyama, Francis. 2010. "Transitions to the Rule of Law." Journal of Democracy 21:1 (January): 33-44.

Gallup Balkan Monitor. http://www.balkan-monitor.eu/index.php/dashboard (July 20, 2013).

Garbett, Claire. 2012. "Transitional Justice and 'National Ownership': An Assessment of the Institutional Development of the War Crimes Chamber of Bosnia and Herzegovina," Human Rights Review 13: 65-84.

Garcia-Godos, Jemima and Knut Andreas. 2010. "Transitional Justice and Victims' Rights before the End of a Conflict: The Unusual Case of Colombia." Journal of Latin American Studies, 42:3: 487-516.

George, Alexander L. and Andrew Bennett. 2005. Case Studies and Theory Development in the Social Sciences. Cambridge, MA: Harvard University. 
Gibney, Mark, Linda Cornett, Reed Wood, Peter Haschke, and Daniel Arnon. 2016. The Political Terror Scale 1976-2015. Date Retrieved, from the Political Terror Scale website: http://www.politicalterrorscale.org (October 6, 2016).

Gibson, James L., Jeffrey Sonis and Sokhom Hean. 2010. "Cambodians Support for the Rule of Law on the Eve of the Khmer Rouge Trials." International Journal of Transitional Justice (4): 377-96.

Guaqueta, Alexandra. 2007. "The way back in: Reintegrating illegal armed groups in Colombia then and now." Conflict, Security \& Development, 7:3, 417-56.

Haggard, Stephen and Lydia Tiede. 2014. "The Rule of Law in Post-Conflict Settings: The Empirical Record." International Studies Quarterly (58): 405-17.

Historical Memory Group. BASTA YA! Colombia: Memories of War and Dignity, Bogota, CNMH. 2016.

Iglesias, Carlos Basombrio. 2012. "Transitional justice and democratic consolidation: The Peruvian experience, In After Oppression: Transitional Justice in Latin America and Eastern Europe. Vesselin Popovski and Monica Serrano, eds. New York: United Nations University Press, 222-42.

InSight Crime. 2016. "Colombia Elites and Organized Crime." http://www.insightcrime.org/images/PDFs/2016/Colombia_Elites_Organized_Crime (January 27, 2017).

International Center for Transitional Justice. 2006. "ICTJ Report: Colombians Want Genuine Peace with Justice,” December 22, 2006.

https://www.ictj.org/sites/default/files/ICTJ-Colombia-Peace-Justice-2006-English_0.pdf (January 20, 2016).

International Center for Transitional Justice. 2009. "Bosnia and Herzegovina Submission to the Universal Periodic Review of the UN Human Rights Council, Seventh Session: February 2010.” https://www.ictj.org/sites/default/files/ICTJ-FormerYugoslaviaBosnia-Review-2009-English.pdf (May 4, 2016).

International Criminal Court, The Office of the Prosecutor. 2012. "Situation in Colombia: Interim Report." November 2012. https://www.icccpi.int/en_menus/icc/structure\%20of\%20the\%20court/office\%20of\%20the\%20prosecuto r/comm\%20and\%20ref/Pages/Situation-in-Colombia-Interim-Report.aspx (January 22, 2016).

International Criminal Tribunal for the Former Yugoslavia (ICTY). http://www.icty.org/en/cases/key-figures-cases (January 28, 2017). 
International Criminal Tribunal for the Former Yugoslavia (ICTY). 2005. "Twelfth annual report of the International Tribunal for the Prosecution of Persons Responsible for Serious Violations of International Humanitarian Law Committed in the Territory of the Former Yugoslavia since 1991." http://www.icty.org/en/documents/annual-reports (May 3, 2017).

International Criminal Tribunal for the Former Yugoslavia (ICTY). 2007. "Fourteenth annual report of the International Tribunal for the Prosecution of Persons Responsible for Serious Violations of International Humanitarian Law Committed in the Territory of the Former Yugoslavia since 1991." http://www.icty.org/en/documents/annual-reports (May $3,2017)$.

International Criminal Tribunal for the Former Yugoslavia (ICTY) Outreach Activities Archives. http://www.icty.org/sections/outreach/outreachactivitiesArchive (November 17, 2013).

Isacson, Adam. 2012. "Consolidating 'Consolidation',” Washington Office on Latin America. December. https://www.wola.org/files/Consolidating_Consolidation.pdf (January 28, 2017).

Ivkovich, Sanja and John Hagan. 2009. "The ICTY, its Constituency, and the Politics: The Battle for Hearts and Minds," (August 2, 2009). Available at SSRN: https://ssrn.com/abstract=1442907 (May 2, 2017).

Jaramillo, Sergio, Yaneth Giha and Paula Torres. 2009. "Transitional Justice and DDR: the Case of Colombia.” International Center for Transitional Justice. (June) https://www.ictj.org/publication/transitional-justice-and-ddr-case-colombia-case-study (October 13, 2015).

Kerr, Rachel. 2004. The International Criminal Tribunal for the Former Yugoslavia: An Exercise in Law, Politics and Diplomacy. London: University of London.

Keza, Ernesto. 2012. "On the Effectiveness of Judicial Accountability Mechanisms in Bosnia and Herzegovina." In After Oppression: Transitional Justice in Latin America and Eastern Europe. Vesselin Popovski and Monica Serrano, eds. New York: United Nations University Press, 245-72.

King, Gary, Robert O. Keohane, and Sidney Verba. 1994. Designing Social Inquiry: Scientific Inference in Qualitative Research. Princeton: Princeton University.

Kleinfeld, Rachel. 2006. "Competing Definitions of the Rule of Law." In Promoting the Rule of Law Abroad: In Search of Knowledge, ed. Thomas Carothers. Washington, D.C: Carnegie Endowment for International Peace, 31-73. 
Lambourne, Wendy. 2009. "Transitional Justice and Peacebuilding after Mass Violence." The International Journal of Transitional Justice (3): 28-48.

Landman, Todd. 2008. Issues and Methods in Comparative Politics: An Introduction. $3^{\text {rd }}$ ed. New York: Routledge.

Laplante, Lisa J. \& Kimberly Theidon. 2006-2007. "Transitional Justice in Times of Conflict: Colombia's Ley de Justicia y Paz." Michigan Journal of International Law, 28(49): 49-108.

LatinNews. http://www.latinnews.com/latin-american-weekly-report.html (January 16, 2017).

Latin American Public Opinion Project (LAPOP). "Cultura politica de la democracia en Colombia, 2015: Actitudes democraticas en zonas de consolidacion territorial." http://www.vanderbilt.edu/lapop/colombia/Colombia-Informe-Especial-2015-070915W.pdf (January 28, 2017).

Latinobarometro. www.latinobarometro.org/latonline.jsp (December 15, 2016). Law 975, Justice and Peace Law. July 25, 2005. English translation. www.verdadabierta.com/.../352-ley-975-de-justicia-y-paz-version-en-ingles (January 21, 2016).

Leebaw, Bronwyn Anne. 2008. "The Irreconcilable Goals of Transitional Justice.” Human Rights Quarterly 30(1): 95-118.

Lopez-Vidal, Roberto. 2012. "Truth-Telling and Internal Displacement in Colombia." July 2012. https://www.ictj.org/sites/default/files/ICTJ-Brookings-Displacement-TruthTelling-Colombia-CaseStudy-2012-English.pdf (January 20, 2016).

Lyons, Amanda and Michael Reed-Hurtado.2010. "ICTJ briefing: Colombia: Impact of the Rome Statute and the International Criminal Court." June 2010. https://www.ictj.org/sites/default/files/ICTJ-Colombia-Impact-ICC-2010-English.pdf (January 20, 2016).

Macdonald, Anna. 2015. "From the Ground Up: What does the evidence tell us about local experiences of transitional justice?" Transitional Justice Review Vol. 1(3): 72-121.

Maas, David, "Fallout from Odebrecht corruption continues in Colombia," Colombia Reports. 19 January 2017. http://colombiareports.com/fallout-odebrecht-corruptioncontinues-colombia/ (January 28, 2017).

Mendez, Juan E. 1997. “Accountability for Past Abuses.” Human Rights Quarterly (19:2): 255-82. 
Moller, Jorgen and Svend-Erik Skaaning. 2014. The Rule of Law: Definitions, Measures, Patterns and Causes. New York: Palgrave Macmillan.

Munck, Gerardo L. and Richard Snyder. 2007. "Debating the Direction of Comparative Politics: An Analysis of Leading Journals." Comparative Political Studies 40:1(January): $5-31$.

Nagy, Rosemary. 2008. "Transitional Justice as Global Project: critical reflections." Third World Quarterly Vol. 29(2): 275-89.

National Center for Historical Memory. http://www.centrodememoriahistorica.gov.co/ micrositios/informeGeneral/estadisticas.html (April 11, 2016).

North Atlantic Treaty Organization (NATO website). http://www.nato.int/cps/en/natohq/topics_52060.htm? and https://www.shape.nato.int/page39511625 (May 3, 2017).

Obradovic, Goran. 2016. "Bosnian Serbs Pay Karadzic, Mladic Personal Expenses," Balkan Insight, 13 April 2016. http://www.balkaninsight.com/en/article/bosnian-serbspay-karadzic-mladic-personal-expenses-04-13-2016 (May 13, 2016).

O'Donnell, Guillermo. 2004. "Why the Rule of Law Matters." Journal of Democracy 15:4(October): 32-46.

Olsen, Tricia D., Leigh A. Payne, and Andrew G. Reiter. 2010. Transitional Justice in Balance: Comparing Processes, Weighing Efficacy. Washington, D.C.: United States Institute of Peace.

Organization of American States Mission to Support the Peace Process in Colombia (MAPP), quarterly and semi-annual reports. https://www.mapp-oea.org/informessemestrales/ (January 28, 2017).

Orentlicher, Diane F. 2010. That Someone Guilty Be Punished: The Impact of the ICTY in Bosnia. New York: Open Society Institute.

Organization for Security and Co-operation in Europe. 2008. "Four Years Later: Follow up of March 2004 Riot Cases before the Kosovo Criminal Justice System." (July). http://www.osce.org/kosovo/32700 (May 3, 2017).

Organization for Security and Co-operation in Europe. 2010. "Kosovo's War Crimes Trials: An Assessment Ten Years on 1999-2009." http://www.osce.org/kosovo/68569 (May 3, 2017). 
Organization for Security and Co-operation in Europe. 2011. "Delivering Justice in Bosnia and Herzegovina: An Overview of War Crimes Processing from 2005 to 2010." (May). http://www.osce.org/bih/108103?download=true (May 3, 2017).

Organization for Security and Co-operation in Europe. 2012. "Independence of the Judiciary in Kosovo: Institutional and Functional Dimensions." (January). http://www.osce.org/kosovo/87138 (May 3, 2017).

Organization for Security and Co-operation in Europe. 2015. "Statistics on War Crimes Cases in BiH." (Given to author by the OSCE Office in BiH, June 2016).

Pachico, Elyssa, "Colombia on Track for Least Violent Year in 3 Decades," InSight Crime, 8 January 2015. http://www.insightcrime.org/news-analysis/colombia-on-trackfor-least-violent-year-in-3-decades (January 27, 2017).

Parkinson, Charles, "Colombia Colonel Sentenced to 19 Years for Paramilitary Ties," InSight Crime, 10 September 2013. http://www.insightcrime.org/news-briefs/colombiacolonel-sentenced-to-19-years-for-paramilitary-ties (January 27, 2017).

Parkinson, Charles, "Colombian Judge Orders Investigation into Uribe's Paramilitary Ties," InSight Crime, 6 September 2013. http://www.insightcrime.org/newsbriefs/colombia-judge-calls-for-investigation-into-uribe-s-paramilitary-ties (January 27, 2017).

Popovski, Vesselin and Monica Serrano, eds. 2012. After Oppression: Transitional Justice in Latin America and Eastern Europe. New York: United Nations University Press.

Reiter, Andrew, Tricia D. Olsen, and Leigh A. Payne. 2013. "Transitional Justice and Civil War: Exploring New Pathways, Challenging Old Guideposts.” Transitional Justice Review 1(1): 137-69.

Report of the High Representative for Implementation of the Peace Agreement on Bosnia and Herzegovina to the Secretary-General of the United Nations (1996-2015). http://www.ohr.int/ (May 3, 2017).

Report of the Secretary General on the United Nations Interim Administration Mission in Kosovo (1999-2015). https://unmik.unmissions.org/key-documents (May 3, 2017).

Republic of Kosovo, Ministry of Foreign Affairs. http://www.mfa-ks.net/?page=2,224 (March 29, 2017). 
Restrepo, Elvira Maria. 2012. "Transitional justice without a compass: Paramilitary demobilization in Colombia." In After Oppression: Transitional Justice in Latin America and Eastern Europe. Vesselin Popovski and Monica Serrano, eds. New York: United Nations University Press, 143-69.

Rodriguez, Daniel B., Mathew D. McCubbins and Barry Weingast. 2010. "The Rule of Law Unplugged." Emory Law Journal (59): 1455-94.

Root, Rebecca. 2012. Transitional Justice in Peru. New York: Palgrave Macmillan.

Sikkink, Kathryn. 2011. The Justice Cascade: How Human Rights Prosecutions Are Changing World Politics. New York: W.W. Norton \& Co.

Snyder, Jack \& Leslie Vinjamuri. 2003/2004. "Trials and Errors: Principle and Pragmatism in Strategies of International Justice.” International Security (28-3): 5-44.

SPSS. "Linear Mixed-Effects Modeling in SPSS: An Introduction to the MIXED Procedure."

http://www.spss.ch/upload/1126184451_Linear\%20Mixed\%20Effects\%20Modeling\%20i n\%20SPSS.pdf (December 28, 2016).

Stromseth, Jane, David Wippman, and Rosa Brooks. 2006. Can Might Make Rights? Building The Rule of Law After Military Interventions. New York: Cambridge University.

Stromseth, Jane E. 2011. "Justice on the Ground? International Criminal Courts and Domestic Rule of Law Building in Conflict-Affected Societies." In Getting to the Rule of Law (Nomos L), ed. James Fleming. New York: New York University.

Subotic, Jelena. 2009. Hijacked Justice: Dealing with the Past in the Balkans. Ithaca: Cornell University.

Subotic, Jelena. 2011. "Expanding the scope of post-conflict justice: Individual, state and societal responsibility for mass atrocity," Journal of Peace Research 48(2): 157-69.

Summers, Nicole. 2012. “Colombia's Victims' Law: Transitional Justice in a Time of Violent Conflict.” Harvard Human Rights Journal, 25: 219-35.

Tate, Winifred. 2009. "From Greed to Grievance: The Shifting Political Profile of the Colombian Paramilitaries." In Colombia: Building Peace in a Time of War ed. Virginia Bouvier. Washington, D.C: United States Institute of Peace, 111-32.

Teitel, Ruti G. 2003. "Transitional Justice Genealogy.” 16 Harvard Human Rights Journal (69): 69-94.

Teitel, Ruti G. 2000. Transitional Justice. New York: Oxford University. 
Thoms, Oskar N.T., James Ron, and Roland Paris. 2010. "State-Level Effects of Transitional Justice: What Do We Know?" The International Journal of Transitional Justice (4): 329-54.

Transitional Justice Database Project. http://www.tjdbproject.com/ (December 26, 2016).

Turner, Catherine. 2008. "Delivering Lasting Peace, Democracy and Human Rights in Times of Transition: The Role of International Law." International Journal of Transitional Justice (2:2): 126-51.

United Nations Development Programme. 2007. "Public Perceptions on Transitional Justice: Report on Transitional Justice Opinion Polling Survey Conducted in April-May 2007 in Kosovo."

http://www.uboconsulting.com/publications/Transitional\%20Justice.pdf (May 2, 2017).

United Nations Development Programme. 2011. "Facing the Past and Access to Justice from a Public Perspective."

http://www.ba.undp.org/content/bosnia_and_herzegovina/en/home/library/crisis_preventi on_and_recovery/facing-the-past-and-access-to-justice.html (May 2, 2016).

United Nations Development Programme. 2012. "Perceptions on Transitional Justice Kosovo 2012." http://www.undp.org/content/dam/kosovo/docs/TJ/EnglishWeb_965257.pdf (May 2, 2017).

United Nations Development Programme. 2011. "Public Pulse 1.” (March). http://www.ks.undp.org/content/kosovo/en/home/library/democratic_governance/-.html (May 3, 2017).

United Nations Development Programme. 2014. "Public Pulse VII." (June). http://www.ks.undp.org/content/kosovo/en/home/library/democratic_governance/publicpulse-7.html (May 3, 2017).

United Nations Development Programme. 2017. "Public Pulse XII.” (January). http://www.ks.undp.org/content/kosovo/en/home/library/democratic_governance/publicpulse-12.html (May 3, 2017).

United Nations Office on Drugs and Crime (UNODC). https://data.unodc.org/ (May 3, 2017).

United Nations Resident Coordinator's Office in Bosnia and Herzegovina. 2013. "Public Opinion Poll Results." http://ba.one.un.org/content/dam/unct/bih/PDFs/Prism\%20Research\%20for\%20UN\%20 RCO_Statistical\%20report.pdf (May 2, 2017). 
United Nations Secretary General. 2004. "The rule of law and transitional justice in conflict and post-conflict societies." S/2004/616.

United States Department of State Human Rights Reports. https://www.state.gov/j/drl/rls/hrrpt/ (January 28, 2017).

United States Department of State Religious Freedom Reports. www.state.gov/j/drl/rls/irf/ (October 14, 2016).

Vanguardia Liberal. "Clan del Golfo estaria contratando a disidentes de las Farce n Antioquia." 26 January 2017: 8A.

Waldron, Jeremy. 2011. "The Rule of Law and the Importance of Procedure." In Getting to the Rule of Law (Nomos L), ed. James Fleming. New York: New York University.

Weber, Max. [1930] 2002. The Protestant Ethic and the Spirit of Capitalism and Other Writings. Trans. Peter Baehr \& Gordon Wells. New York: Penguin Group.

Weiffen, Brigitte. 2012. "The Forgotten Factor-the Impact of transitional justice on the development of the rule of law in processes of democratization." Zeitsehrift fur Vergleichende Politikwissenschaft 6:2 (November).

World Bank. http://data.worldbank.org/indicator/NY.GDP.PCAP.CD (October 14, 2016).

World Bank. http://data.worldbank.org/indicator/NY.GDP.TOTL.RT.ZS?locations=BA (October 14, 2016).

Worldwide Governance Indicators. http://info.worldbank.org/governance/wgi/index.aspx\#home (October 14, 2016). 


\section{APPENDICES}

\section{Appendix A \\ WGI Rule of Law Sources \& Their Indicators}

Bertelsmann Transformation Index (BiH, Kosovo, Colombia and Peru)

Separation of Powers

Independent Judiciary

Civil Rights

Business Enterprise Environment Survey (BiH and Kosovo)

How often is the following characteristic associated with the court system: fair and honest?

How often is the following characteristic associated with the court system: enforceable?

How often is the following characteristic associated with the court system: quick?

How problematic is crime for the growth of your business?

How problematic is the judiciary for the growth of your business?

Cingranelli Richards Human Rights Database and Political Terror Scale (BiH, Kosovo, Colombia and Peru)

Political Terror Scale (state-led political violence)

Economist Intelligence Unit Riskwire and Democracy Index (BiH, Kosovo, Colombia and Peru)

Violent Crime

Organized Crime

Fairness of judicial process

Enforceability of contracts

Speediness of judicial process

Confiscation/expropriation

Intellectual property rights protection

Private property protection

Freedom House (BiH and Kosovo)

Judicial framework and independence

Freedom House Countries at the Crossroads (Colombia and Peru)

Rule of law

Gallup World Poll (BiH, Kosovo, Colombia and Peru)

Confidence in the police force

Confidence in the judicial system

Have you had money/property stolen from you or another household member?

Have you been assaulted or mugged? 
Global Integrity Index (BiH, Kosovo, Colombia and Peru)

Public management

Rights

Gender

Global Insight Business Conditions and Risk Indicators (BiH, Colombia and Peru)

Expropriation of private businesses

State contract alteration

Contract enforcement

Heritage Foundation Index of Economic Freedom (BiH, Kosovo, Colombia and Peru)

Property Rights

IFAD Rural Sector Performance Assessments (BiH, Colombia and Peru)

Access to land

Access to water for agriculture

Institute for Management and Development World Competitiveness Yearbook (Colombia and Peru)

Tax evasion is a common practice in your country

Justice is not fairly administered in society

Personal security and private property are not adequately protected

Parallel economy impairs economic development in your country

Patent and copyright protection are not adequately enforced in your country

Institutional Profiles Database (BiH, Colombia and Peru)

Degree of security of goods and persons by criminal organizations

Degree of judicial independence vis-à-vis the State

Degree of enforcement of court orders

Timeliness of judicial decisions

Equal treatment of foreigners before the law (compared to nationals)

Practical ability of the administration to limit tax evasion

Efficiency of the legal means to protect property rights in the event of conflict between private stakeholders?

Generally speaking, does the State exercise arbitrary pressure on private property (e.g. red tape...)?

Does the State pay compensation equal to the loss in cases of expropriation (by law or fact) when the expropriation concerns land ownership?

Does the State pay compensation equal to the loss in cases of expropriation (by law or fact) when the expropriation concerns production means?

Degree of observance of contractual terms between national private stakeholders

Degree of observance of contractual terms between national and foreign private stakeholders

In the past 3 years, has the State withdrawn from contracts without paying the corresponding compensation... vis-à-vis national stakeholders? 
In the past 3 years, has the State withdrawn from contracts without paying the corresponding compensation... vis-à-vis foreign stakeholders?

Respect for intellectual property rights relating to... trade secrets and industrial patents Respect for intellectual property rights

Latinobarometro (Colombia and Peru)

Trust in judiciary

Trust in police

Have you been a victim of crime?

Political Risk Services International Country Risk Guide (Colombia and Peru)

Law and order

United States Department of State Trafficking in Persons Report (BiH, Kosovo, Colombia and Peru)

Trafficking in persons

Vanderbilt University Americas Barometer (Colombia and Peru)

Trust in supreme court

Trust in justice system

Trust in police

Have you been a victim of crime?

World Bank Country Policy and Institutional Assessments (BiH, Kosovo, Colombia and Peru)

Property rights and rule-based governance

World Economic Forum Global Competitiveness Report (BiH, Colombia and Peru)

Business cost of crime and violence

Cost of organized crime

Reliability of police services

Judicial independence

Efficiency of legal framework for challenging regulations

Individual property rights protection

Informal sector

World Justice Project Rule of Law Index (BiH, Colombia and Peru)

Order and security

Criminal justice

Civil justice 


\section{Appendix B}

Yearly Categorization of Transitional Justice

\begin{tabular}{|c|c|c|c|c|}
\hline Year & $\mathrm{BiH}$ & Colombia & Kosovo & Peru \\
\hline 1996 & I & - & - & - \\
\hline 1997 & I & - & - & - \\
\hline 1998 & $\mathrm{I}$ & - & - & - \\
\hline 1999 & $\mathrm{I}$ & - & $\mathrm{M}$ & - \\
\hline 2000 & $\mathrm{I}$ & - & $\mathrm{I}$ & - \\
\hline 2001 & I & - & I & $\mathrm{D}$ \\
\hline 2002 & I & - & I & $\mathrm{D}$ \\
\hline 2003 & I & - & I & $\mathrm{D}$ \\
\hline 2004 & I & - & I & $\mathrm{D}$ \\
\hline 2005 & $\mathrm{M}$ & $\mathrm{D}$ & $\mathrm{I}$ & $\mathrm{D}$ \\
\hline 2006 & $\mathrm{M}$ & $\mathrm{D}$ & $\mathrm{I}$ & $\mathrm{D}$ \\
\hline 2007 & $\mathrm{M}$ & $\mathrm{D}$ & $\mathrm{I}$ & $\mathrm{D}$ \\
\hline 2008 & $\mathrm{M}$ & $\mathrm{D}$ & $\mathrm{I}$ & $\mathrm{D}$ \\
\hline 2009 & $\mathrm{M}$ & $\mathrm{D}$ & $\mathrm{M}$ & $\mathrm{D}$ \\
\hline 2010 & $\mathrm{M}$ & $\mathrm{D}$ & $\mathrm{M}$ & $\mathrm{D}$ \\
\hline 2011 & $\mathrm{M}$ & $\mathrm{D}$ & $\mathrm{M}$ & $\mathrm{D}$ \\
\hline 2012 & $\mathrm{M}$ & $\mathrm{D}$ & $\mathrm{M}$ & $\mathrm{D}$ \\
\hline 2013 & $\mathrm{M}$ & $\mathrm{D}$ & $\mathrm{M}$ & $\mathrm{D}$ \\
\hline 2014 & $\mathrm{M}$ & $\mathrm{D}$ & $M$ & $\mathrm{D}$ \\
\hline 2015 & $\mathrm{M}$ & $\mathrm{D}$ & $\mathrm{M}$ & $\mathrm{D}$ \\
\hline
\end{tabular}

$\mathrm{I}=$ International; $\mathrm{M}=$ Mixed; $\mathrm{D}=$ Domestic 


\section{Appendix C \\ Independent Sample T Tests}

\section{Bosnia}

\section{Group Statistics}

\begin{tabular}{|ll|r|r|r|}
\hline & $\begin{array}{l}\text { International/Mixed/Domestic } \\
\text { Type of Transitional Justice }\end{array}$ & \multicolumn{1}{|c|}{$\mathrm{N}$} & \multicolumn{1}{c|}{ Mean } & Std. Deviation \\
\hline Yearly Rule of Law Level & International & 6 & -.5650 & .16526 \\
& Mixed & 11 & -.3545 & .13269 \\
\hline
\end{tabular}

\section{Group Statistics}

\begin{tabular}{|ll|r|}
\hline & $\begin{array}{l}\text { International/Mixed/Domestic Type of } \\
\text { Transitional Justice }\end{array}$ & $\begin{array}{c}\text { Std. Error } \\
\text { Mean }\end{array}$ \\
\hline Yearly Rule of Law Level & International & .06747 \\
& Mixed & .04001 \\
\hline
\end{tabular}

\section{Independent Samples Test}

\begin{tabular}{|ll|c|c|c|}
\hline \multirow{2}{n}{} & & \multicolumn{2}{|c|}{$\begin{array}{c}\text { Levene's Test for Equality of } \\
\text { Variances }\end{array}$} & $\begin{array}{c}\text { Equality of } \\
\text { Means }\end{array}$ \\
\cline { 3 - 5 } & & F & Sig. & t \\
\hline Yearly Rule of Law Level & Equal variances assumed & .324 & .577 & -2.872 \\
& Equal variances not assumed & & & -2.683 \\
\hline
\end{tabular}

Independent Samples Test

\begin{tabular}{|ll|r|r|r|}
\hline \multirow{2}{*}{} & & \multicolumn{3}{|c|}{ t-test for Equality of Means } \\
\cline { 3 - 5 } & & df & $\begin{array}{c}\text { Sig. (2- } \\
\text { tailed) }\end{array}$ & $\begin{array}{c}\text { Mean } \\
\text { Difference }\end{array}$ \\
\hline Yearly Rule of Law Level & Equal variances assumed & 15 & .012 & -.21045 \\
& Equal variances not assumed & 8.603 & .026 & -.21045 \\
\hline
\end{tabular}


Independent Samples Test

\begin{tabular}{|ll|r|r|r|}
\hline \multirow{2}{*}{$n$} & \multicolumn{3}{|c|}{$\mathrm{t}$-test for Equality of Means } \\
\cline { 3 - 5 } & & & \multicolumn{1}{c|}{$\begin{array}{c}90 \% \text { Confidence Interval } \\
\text { of the Difference }\end{array}$} \\
\cline { 3 - 6 } & Std. Error & Lower & Upper \\
\hline Yearly Rule of Law Level & Equal variances assumed & .07327 & -.33890 & -.08201 \\
& Equal variances not assumed & .07844 & -.35500 & -.06591 \\
\hline
\end{tabular}

\section{Kosovo}

\section{Group Statistics}

\begin{tabular}{|ll|r|r|r|}
\hline & $\begin{array}{l}\text { International/Mixed/Domestic } \\
\text { Type of Transitional Justice }\end{array}$ & \multicolumn{1}{c|}{$\mathrm{N}$} & \multicolumn{1}{c|}{ Mean } & \multicolumn{1}{c|}{ Std. Deviation } \\
\hline Yearly Rule of Law Level & International & 5 & -.9420 & .10085 \\
& Mixed & 8 & -.5625 & .06251 \\
\hline
\end{tabular}

\section{Group Statistics}

\begin{tabular}{|ll|r|}
\hline & $\begin{array}{l}\text { International/Mixed/Domestic Type of } \\
\text { Transitional Justice }\end{array}$ & $\begin{array}{c}\text { Std. Error } \\
\text { Mean }\end{array}$ \\
\hline Yearly Rule of Law Level & International & .04510 \\
& Mixed & .02210 \\
\hline
\end{tabular}

Independent Samples Test

\begin{tabular}{|ll|r|r|c|}
\hline \multirow{2}{n}{} & & \multicolumn{2}{c|}{$\begin{array}{c}\text { Levene's Test for Equality of } \\
\text { Variances }\end{array}$} & $\begin{array}{c}\text { E-test for } \\
\text { Equality of } \\
\text { Means }\end{array}$ \\
\cline { 3 - 5 } & & F & Sig. & $\mathrm{t}$ \\
\hline Yearly Rule of Law Level & Equal variances assumed & 1.090 & .319 & -8.465 \\
& Equal variances not assumed & & & -7.556 \\
\hline
\end{tabular}


Independent Samples Test

\begin{tabular}{|ll|r|r|r|}
\hline \multirow{2}{*}{} & & \multicolumn{3}{|c|}{ t-test for Equality of Means } \\
\cline { 3 - 5 } & & & & \\
Yearly Rule of Law Level & Equal variances assumed & Sig. (2-tailed) & $\begin{array}{c}\text { Mean } \\
\text { Difference }\end{array}$ \\
\hline & Equal variances not assumed & 5.955 & .000 & -.37950 \\
& & & .000 & -.37950 \\
\hline
\end{tabular}

Independent Samples Test

\begin{tabular}{|lc|r|r|r|}
\hline \multirow{2}{*}{$n$} & \multicolumn{3}{|c|}{$\mathrm{t}$-test for Equality of Means } \\
\cline { 3 - 5 } & & & \multicolumn{2}{c|}{$\begin{array}{c}90 \% \text { Confidence Interval } \\
\text { of the Difference }\end{array}$} \\
\cline { 3 - 5 } & & $\begin{array}{c}\text { Std. Error } \\
\text { Difference }\end{array}$ & Lower & Upper \\
\hline Yearly Rule of Law Level & Equal variances assumed & .04483 & -.46001 & -.29899 \\
& Equal variances not assumed & .05022 & -.47722 & -.28178 \\
\hline
\end{tabular}




\section{Appendix D \\ List of Variables \& Their Sources}

Independent Variable: Mechanisms/Models of Transitional Justice

Sources: Transitional Justice Database Project: http://www.tjdbproject.com/ \& my own fieldwork and coding.

Dependent Variable: Rule of Law

Source: Worldwide Governance Indicators:

http://info.worldbank.org/governance/wgi/index.aspx\#home

\section{Control Variables}

GDP Per Capita (Yearly)

Source: World Bank: http://data.worldbank.org/indicator/NY.GDP.PCAP.CD

Total Natural Resources Rents as a Percentage of GDP (Yearly)

Source: World Bank:

http://data.worldbank.org/indicator/NY.GDP.TOTL.RT.ZS?locations=BA

(Country) Yearly Percentage of Protestants

Source: United States Department of State: www.state.gov/j/drl/rls/irf/ 


\section{Appendix E \\ Colombia Interview Questions}

Q. What was the process during the drafting and ratification of the Justice and Peace Law? Were there any Congressional hearings?

Q. Does the Fiscalia's Special Directorate on Transitional Justice have enough personnel and resources to finish the process under Law 975 as well as investigate and prosecute new cases emerging from the FARC and possibly the ELN peace processes?

Q. How many of the 35 individuals sentenced have finished the appeals process?

Q. How many cases are still underway or are awaiting trial?

Q. Is prosecution solely based on the perpetrators confessions/desire to be part of this process?

Q. After a demobilized serves his sentence and probation period is his conviction expunged?

Q. If someone is convicted now under 975 , will he go to jail?

Q. According to Article 44.3 of Law 975, the perpetrators are to make a public statement of repentance and ask for forgiveness. When and how does this take place?

Q. Why have there been only 526 cases of requests for forgiveness or public acknowledgement/repentance?

Q. How does Law 1424 of 2010 relate/change Law 975 ?

Q. How many witnesses, victims and their leaders have been killed since 2005 ?

Q. Of those 30 or more senior paramilitary leaders extradited to the United States since 2006, how many are still cooperating in the Justice and Peace process?

Q. How many individuals received de-facto amnesties under the Justice and Peace Law? 
Q. How does the Fiscalia share with the victims or publicly announce verdicts reached after a trial?

Q. How much of the reparations fund came from the demobilized and how much from the Government of Colombia?

Q. Some international reports indicate that the $\mathrm{GoC}$ will not have enough money to fully implement Law 1448. Has the GoC allocated more than the initial \$29 billion for this law?

Q. Aside from judicial expediency, why did the GoC shift transitional justice strategies, i.e., from the justice and peace process to the new Legal Framework for Peace?

Q. Can you please describe the elements of the Legal Framework for Peace?

Q. Do you have any polling data on Colombian attitudes toward transitional justice?

Q. How has civil society provided input into the agreement on victims?

Q. How does the government intend to enhance the presence and strength of the state in conflict-affected regions?

Q. How would you rate the rule of law in Colombia; poor, good or above the regional average?

Q. What is the biggest impediment to improving the rule of law in Colombia?

Q. What was the effect of the change in criminal code in 2005 on the development of the rule of law? 


\section{Appendix F \\ BiH \& Kosovo Interview Questions}

Bosnia and Herzegovina

Q. How would you rate the performance of the ICTY in prosecuting individuals

responsible for

war crimes during the 1992-1995 conflict? (poor-average-good)

Q. How did the arrests/convictions of Karadzic and Mladic influence Bosnian views of the ICTY?

Q. As the ICTY completes its mandate, what is its greatest legacy in $\mathrm{BiH}$ ?

Q. Besides helping create the War Crimes Chamber (WCC), what other type of assistance, direct

or indirect, did the ICTY provide judicial institutions in $\mathrm{BiH}$ ?

Q. Are there any international judges or prosecutors still working in the WCC or Special

Department for War Crimes? How would you assess their contributions in assisting local institutions?

Q. How many cases has the WCC completed? How many cases remain?

Q. Assess the impact of the 2003 change in criminal code and criminal procedure code.

Q. How does the governing structure of $\mathrm{BiH}$ help or hurt in the prosecution of war crimes and the development of a shared understanding of the rule of law? Has the application of criminal codes been harmonized between the state and entities?

Q. Do you/your ministry/agency view transitional justice in $\mathrm{BiH}$ as internationally imposed or domestically developed and implemented?

Q. Where is BiH today in meeting the prosecutorial goals of its National Strategy? 
Q. Is the government of $\mathrm{BiH}$ or either of the two entities considering other mechanisms of transitional justice, such as a truth commission, reparations or amnesties?

Q. How many individuals remain missing in $\mathrm{BiH}$ ?

Q. How would you rate the rule of law in BiH today? (poor-average-good)

Q. What is the biggest obstacle to improving the rule of law?

Q. What changes are being implemented or envisioned in the judicial branch/police force for eventual European Union membership? Has potential EU membership improved the rule of law?

Q. How do you view the ethnic future of the state of BiH? Can Bosniaks, Serbs and Croats live together in a unified state?

Q. How would you assess regional cooperation on war crimes and rule of law issues, such as corruption?

Kosovo

Q. How would you rate the performance of the ICTY in prosecuting individuals responsible for war crimes from the 1998-1999 conflict? (poor-average-good)

Q. As the ICTY completes its mandate, what is its greatest legacy in Kosovo?

Q. What type of assistance, direct or indirect, did the ICTY provide judicial institutions in Kosovo?

Q. Are there any international judges or prosecutors still working on war crimes? How would you assess their contributions in assisting local institutions?

Q. How many war crimes cases have been completed in Kosovo?

Q. Why after the ICTY and prosecutions in Kosovo does Kosovo need a new war crimes court in The Hague? How will it be different? 
Q. Is there any role for the Kosovars in operating this court?

Q. Do you/your ministry/agency view transitional justice in Kosovo as internationally imposed or has there been sufficient domestic consultation?

Q. Is the government of Kosovo considering other mechanisms of transitional justice, such as a truth commission (RECOM), reparations or amnesties?

Q. How many individuals remain missing in Kosovo?

Q. How would you rate the rule of law in Kosovo today? (poor-average-good)

Q. What is the biggest obstacle to improving the rule of law?

Q. What changes are being implemented or envisioned in the judicial branch/police force for eventual European Union membership? Has potential EU membership improved the rule of law?

Q. How would you assess regional cooperation on war crimes and rule of law issues, such as corruption? 
VITA

\title{
CRAIG LANG
}

\author{
B.A. Political Science \\ Cedarville University \\ Cedarville, Ohio
}

2001-2011

Foreign Affairs Officer

U.S. Department of State

Washington, D.C.

2015-Present

Doctoral Candidate

Florida International University

Miami, Florida

2015-Present

Adjunct Instructor

Florida International University

Miami, Florida

\section{PRESENTATIONS}

Lang, Craig. (November 2013). The ICTY's Impact on the Development and Perception of the Rule of Law in Kosovo. Paper presented at the annual conference of the Association for Slavic, East European and Eurasian Studies, Boston, MA.

Lang, Craig. (May 2014). The Role of the State: Modern State-Building Efforts in Colombia and Peru. Paper presented at the annual conference of the Latin American Studies Association, Chicago, IL.

Lang, Craig. (November 2016). The Impact of Transitional Justice on the Development of the Rule of Law. Paper presented at the annual conference of the Northeastern Political Science Association Annual Conference, Boston, MA. 